\title{
ACCESSION TO THE WORLD TRADE ORGANIZATION DOES SIZE MATTER?
}

\author{
by
}

\author{
Garth Ehrhardt
}

A thesis submitted to the Faculty of Graduate and Postdoctoral Affairs in partial fulfillment of the requirements for the degree of

Master of Arts

in

The Norman Paterson School of International Affairs

Carleton University

Ottawa, Ontario

(C) 2012, Garth Ehrhardt 
Library and Archives

Canada

Published Heritage

Branch

395 Wellington Street

Ottawa ON K1A ON4

Canada
Bibliothèque et

Archives Canada

Direction du

Patrimoine de l'édition

395 , rue Wellington

Ottawa ON K1A ON4

Canada
Your file Votre référence

ISBN: 978-0-494-91561-5

Our file Notre référence

ISBN: $978-0-494-91561-5$
NOTICE:

The author has granted a nonexclusive license allowing Library and Archives Canada to reproduce, publish, archive, preserve, conserve, communicate to the public by telecommunication or on the Internet, loan, distrbute and sell theses worldwide, for commercial or noncommercial purposes, in microform, paper, electronic and/or any other formats.

The author retains copyright ownership and moral rights in this thesis. Neither the thesis nor substantial extracts from it may be printed or otherwise reproduced without the author's permission.
AVIS:

L'auteur a accordé une licence non exclusive permettant à la Bibliothèque et Archives Canada de reproduire, publier, archiver, sauvegarder, conserver, transmettre au public par télécommunication ou par l'Internet, prêter, distribuer et vendre des thèses partout dans le monde, à des fins commerciales ou autres, sur support microforme, papier, électronique et/ou autres formats.

L'auteur conserve la propriété du droit d'auteur et des droits moraux qui protege cette thèse. $\mathrm{Ni}$ la thèse ni des extraits substantiels de celle-ci ne doivent être imprimés ou autrement reproduits sans son autorisation.
In compliance with the Canadian Privacy Act some supporting forms may have been removed from this thesis.

While these forms may be included in the document page count, their removal does not represent any loss of content from the thesis.
Conformément à la loi canadienne sur la protection de la vie privée, quelques formulaires secondaires ont été enlevés de cette thèse.

Bien que ces formulaires aient inclus dans la pagination, il n'y aura aucun contenu manquant. 


\begin{abstract}
The process of accession to the World Trade Organization (WTO) is inherently openended. While negotiations are guided by certain procedural norms, there are no baseline concessions required of acceding countries in terms of trade liberalization or established criteria for assessing compliance of prospective members' domestic legislation with WTO rules. As a result, the experiences of acceding countries have varied widely in terms of the complexity and length of negotiations as well as their outcomes. This paper examines the variability in WTO accession negotiations, attempts to elucidate its primary causes, and explores the implications it has for acceding countries and the WTO accession process in general. The research findings suggest that acceding countries that play a larger role in the global economy are systematically subjected to more negotiating scrutiny during the access process and are generally, but not always, required to undergo more trade liberalization before becoming WTO members.
\end{abstract}




\section{Acknowledgments}

I would like to thank my employer, Agriculture and Agri-Food Canada, for supporting my post-graduate studies. I would like to thank Professor Michael Hart for his wise counsel and for pushing me to be intellectually rigorous in my research. Finally, I would like to thank Brian Morrisey for being so generous with his time and for graciously sharing his immeasurable expertise and experience in trade policy and WTO accession negotiations. 


\section{Table of Contents}

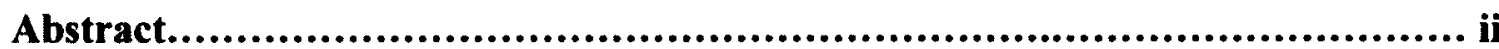

Acknowledgements................................................................... iii

Table of Contents............................................................................ iv

Chapter 1: Introduction..................................................................1

Chapter 2: Why Countries Join the WTO............................................. 6

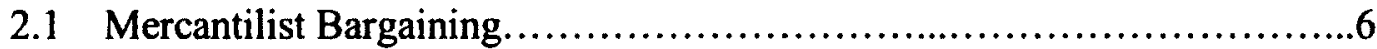

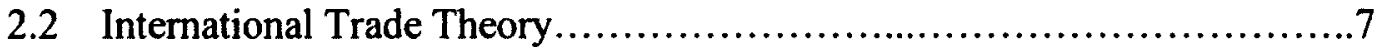

2.3 Empirical Studies on Trade and Economic Growth........................ 9

Chapter 3: How Countries Join the WTO..............................................13

3.1 Bargaining Power in International Trade Negotiations....................13

3.2 The WTO Accession Process..........................................16

3.3 Critiques of the Accession Process.................................... 18

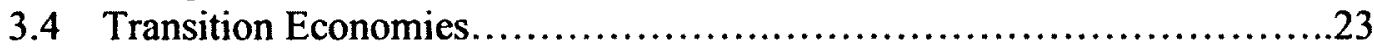

Chapter 4: Methodology.............................................................25

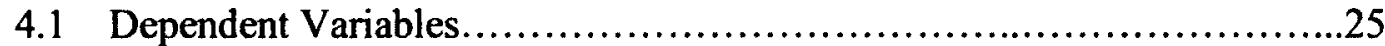

4.2 Independent Variables.............................................. 30

4.3 Quantitative Analysis...................................................

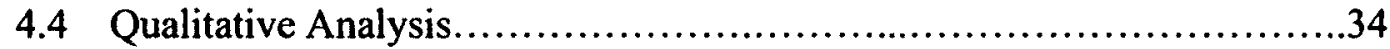

Chapter 5: Baseline Data.................................................................37

5.1 Economy Size, Trade Value, Trade Diversity and Negotiating Scrutiny.....37

5.2 Economy Size, Trade Value, Trade Diversity and Trade Liberalization.....41

5.3 Summary of Findings.................................................44

Chapter 6: Case Studies: Part 1 - Central and Eastern European Countries......45

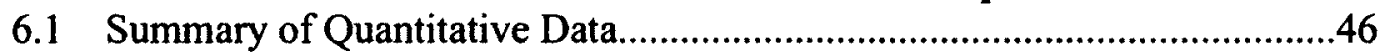

6.2 Kyrgyzstan.......................................................48

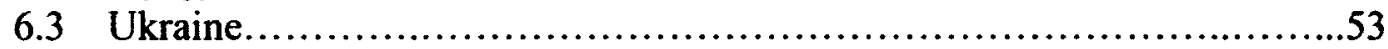

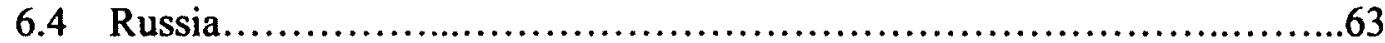

Chapter 7: Case Studies: Part 2 - Asian Countries...................................78

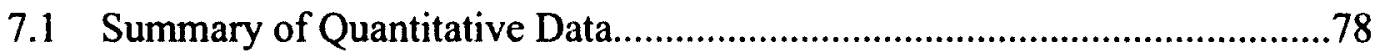

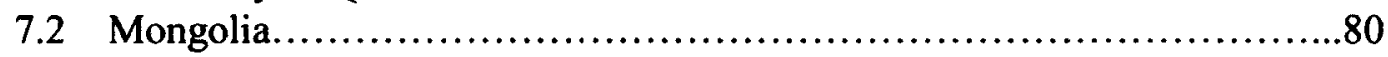

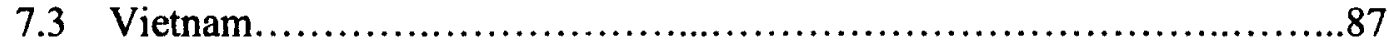

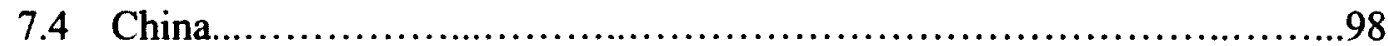

Chapter 8: Case Studies: Part 3 - Middle Eastern Countries.......................119

8.1 Summary of Quantitative Data...................................................................120

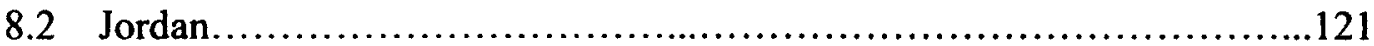

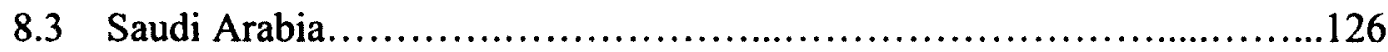

Chapter 9: Summary of Findings and Conclusion...................................132

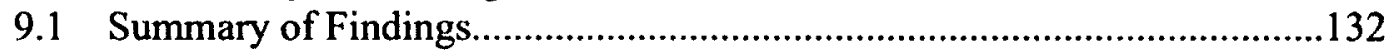

9.2 Conclusion.................................................................

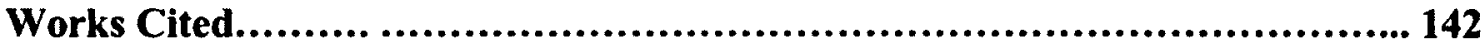




\section{INTRODUCTION}

Two of the major successes of the World Trade Organization (WTO) since the conclusion of the Uruguay Round have been the steady expansion of membership, which stands at 153 countries as of January 1,2012 , and the continual stream of applicants. ${ }^{1}$ Since January 1, 1995, 25 countries have acceded to the WTO. An additional 30 countries are currently in the process of acceding. Despite the evolution of a common set of guiding principles and procedures (WTO "Technical Note on the Accession Process") the WTO accession process remains very open-ended. In fact, Article XII of the Marrakesh agreement establishing the WTO provides only the following guidance:

Any State or separate customs territory possessing full autonomy in the conduct of its external commercial relations and of the other matters provided for in this Agreement and the Multilateral Trade Agreements may accede to this Agreement, on terms to be agreed between it and the WTO [emphasis added].

In other words, there are no baseline (minimum or maximum) concessions required of acceding countries in terms of trade liberalization. ${ }^{2}$ And, there are no established criteria that prospective members must meet in demonstrating compliance of domestic legislation with WTO rules. Instead, acceding members must open their markets and show compliance with WTO rules to whatever extent existing members deem sufficient.

As a result of this structural feature of the accession process, the experiences of acceding countries have varied widely in terms of the complexity and length of negotiations as well as their outcomes. Even the most superficial analysis reveals

\footnotetext{
' Negotiations on the accessions of Montenegro, Russia, Samoa and Vanuatu were concluded in 2011. All four countries are expected to formally join the WTO in 2012 once their respective accession protocols receive the required domestic approvals.

${ }^{2}$ Throughout this paper the term trade liberalization refers broadly to reductions in government controls which restrict entry of goods and services to the domestic market, affect their treatment within that market, and/or restrict the export of goods and services from that market.
} 
significant differences. For instance, negotiations on Russia's accession to the WTO recently concluded after nearly 19 years, while China took 15 years to negotiate the terms of its membership. In contrast, smaller countries such as Kyrgyzstan and Croatia took only five and seven years respectively to conclude the accession process. Differences are also apparent in negotiating outcomes. For example, Bulgaria acceded to the WTO with an average bound tariff of 5.5 percent, while Panama was allowed an average bound tariff of 23.5 percent.

This paper examines the variability in WTO accession negotiations, attempts to elucidate its primary causes, and explores the implications it has for acceding countries and the WTO accession process in general. The main variable addressed in this paper is the importance of an acceding country to the global economy. This variable is measured in the following three ways: the size of a country's economy, the value of its international trade flows, and the diversity of its trade flows. Given that the issues within the WTO's mandate - international trade rules - are fundamentally economic in nature, it is reasonable to expect that economic factors such as these should be the primary determinants of a country's behavior and how it is treated in the organization. Based on this logic, the main purpose of this paper is to answer the following questions:

- What effects do the size of an applicant country's economy, the value of its trade flows and its trade diversity have on its WTO accession negotiations?

- What effects do the size of an applicant country's economy, the value of its trade flows and its trade diversity have on its eventual WTO commitments? 
Although it must be acknowledged that a great number of economic and political factors can influence accession negotiations, this paper puts forth a two-part hypothesis to address these questions:

(1) Acceding countries with larger economies and larger and more diversified trade flows are subjected to increased scrutiny from WTO members over the course of their accession negotiations.

(2) As a result of the increased negotiating scrutiny to which they are subjected, countries with larger economies and larger and more diversified trade flows are required to undergo more trade liberalization in order to accede to the WTO.

This paper argues that both phenomena occur because existing members invest greater resources in negotiations that are of greater consequence to them from an economic or commercial policy perspective. A competing hypothesis is that acceding countries with larger economies are able to leverage their market power in the negotiating process and thereby more effectively withstand and counteract pressure from WTO members to undergo trade liberalization. This could manifest itself both in terms of seeking transition periods or exemptions vis-à-vis the implementation of WTO rules and in terms of less significant tariff and other market-access concessions. Using the same logic, one could also predict that smaller countries are less well equipped for the negotiating process and despite being subjected to less scrutiny, may take on equivalent or more significant trade liberalizing commitments as a result of having less negotiating leverage.

The theoretical basis for these hypotheses is addressed in greater detail in subsequent chapters. However, it is useful to note from the outset that the assumptions from which they are derived are rooted in the concept of mercantilist bargaining. Under 
this negotiating model, countries seek to maximize their access to foreign markets, while giving up as little as possible in terms of liberalizing their domestic markets. In this sense, governments see foreign market opening and the resultant export opportunities as a political gain, and domestic market opening and the resultant import competition as a cost. Although it is not perfectly applicable in every situation, the concept of mercantilist bargaining underpins many international trade negotiations, including those taking place in the context of WTO accessions.

In testing these hypotheses, this paper employs a methodological approach that incorporates both quantitative and qualitative elements. The main thrust of the quantitative research focuses on establishing some baseline trends among economy size, trade volumes and trade diversity and various quantifiable measures of the accession process and its outcomes. The degree of negotiating scrutiny to which an applicant country is subjected in the accession process is measured based on the size of the WTO working party, the number of working party meetings and the length of the working party report. The degree of trade liberalization embodied in the negotiating outcomes is assessed based on the final bound tariff rates, the number of commitment paragraphs in the working party report and the number of specific service sub-sector commitments. The qualitative component of the paper involves a three-part case study. The first part analyses and compares the WTO accession negotiations of Kyrgyzstan, Ukraine and Russia. The second part analyses and compares the WTO accession negotiations of Mongolia, Vietnam and China. The third part presents a brief review of the WTO accession negotiations of Jordan and Saudi Arabia to ensure that research findings are generally applicable to non-transition economies. These case studies are designed to 
provide deeper insight into the general trends identified in the quantitative analysis, and serve as a vehicle to assess some of the common critiques of the WTO accession process. The paper is divided into three main sections. The first section, which includes chapters two, three and four, examines why and how countries join the WTO, provides the theoretical foundation for the remainder of the paper and explains the research methodology. The second section, which includes chapters five, six, seven and eight, presents quantitative and qualitative research findings. The third and concluding section, chapter nine, summarizes and interprets research findings with an emphasis on implications for current and future WTO accession negotiations, as well as the accession process itself. 


\section{WHY COUNTRIES JOIN THE WTO}

In order to have an informed discussion about the WTO accession process and appreciate the implications of the research findings, it is necessary to have an understanding of the broader theoretical, empirical and policy debates surrounding this topic. To this end, the following section explores why countries accede to the WTO and provides a brief review of research on the impacts of trade liberalization on economic growth.

\subsection{Mercantilist Bargaining}

Although individual accession negotiations are shaped by a variety of short-term political and economic factors, the common underlying long-term objective of the majority of acceding members is to pursue greater integration into the global economy. This means not only increasing trade flows, but also boosting foreign investment and tapping into global value-chains. In order to benefit from the most-favoured-nation (MFN) treatment accorded among WTO members, acceding countries must reduce barriers to trade and align their laws and regulations with WTO rules. This approach to negotiations is encapsulated in Dymond and Hart's concept of 'mercantilist bargaining'

According to Dymond and Hart, the opportunity to pursue improved access to export markets through multilateral trade negotiations (such as WTO accession negotiations) provides policy-makers with the necessary cover to agree to liberalizing reforms that may be politically difficult in the short-term, but are in the long-term economic interests of the country as whole. For instance, unilaterally reducing tariffs and exposing so-called "sensitive sectors" (common examples include agriculture, textile 
manufacturing and automobile manufacturing) to international trade can result in shortterm job losses and other adjustment costs that are not politically tenable for governments. However, in the context of a multilateral negotiation, these types of 'concessions' and the short-term political losses associated with them, can be offset by broader political gains achieved through improved access to export markets for other economic sectors. In this sense, mercantilist negotiating allows governments to strike a balance that is acceptable to voters and other constituents, while also promoting economic growth.

Furthermore, once liberalizing reforms have been put in place, WTO membership locks them in as part of a country's international legal obligations and thereby prevents any backsliding. As a result, WTO membership amounts to an important 'stamp of approval' for a county's trade policy regime and sends a positive signal to would-be investors and trading partners. This can be particularly important for developing countries and transition economies that have often been isolated from the global economy. Finally, WTO membership provides admission into the international community, which allows countries to participate actively in shaping the interpretation of existing trade rules and developing future rules. ${ }^{3}$

\subsection{International Trade Theory}

The rationale for WTO accession outlined in the preceding paragraph is based fundamentally on a belief that trade liberalization can be a driver of economic growth. This belief is derived from a vast body of theory and empirical research dating back to the eighteenth century and Adam Smith's The Wealth of Nations, from which the concept

\footnotetext{
${ }^{3}$ Although this question falls beyond the scope of this paper, a major criticism of the Uruguay Round was that developing countries did not get to have much influence over the formulation of trade rules. Some would also argue that the reluctance of developed countries to let developing countries have more influence is a major contributing factor to the current stalemate in the Doha Round.
} 
of absolute advantage is derived. According to Smith's model, trade results in welfare gains as it allows countries to specialize in the production of goods that they can produce at the lowest absolute cost compared to other countries. David Ricardo's On the Principles of Political Economy and Taxation put forth a variant on Smith's approach with his concept of comparative advantage. According to the law of comparative advantage, trading countries will specialize in the production of goods that they can produce at the lowest relative cost (often referred to as 'opportunity cost') compared to other countries. The concept of 'opportunity cost' is crucial because it precludes the possibility that a country will have a comparative advantage in the production of every good, and guarantees that every country will have a comparative advantage in the production of something. In other words, trade is not a zero-sum game and all countries can benefit from it irrespective of their level of development. Among the most influential derivatives of Ricardian theory is the Hecskscher-Ohlin model, according to which trade is based on factor endowments. This model predicts that a country will export goods intensive in the factors of production that are abundant in that country, and import goods intensive in the factors that are scarce (Ohlin). Here again, gains from trade are derived from specialization that results from differences among countries.

New trade theories designed to account for the importance of intra-industry trade and trade between countries with similar resource endowments point to a different set of incentives to trade and related welfare gains. For example, Krugman's model of monopolistic competition posits that trade gives firms access to larger markets which allows them to increase cost-efficiency by taking advantage of increasing returns to scale. This model also predicts gains from competition as the least efficient firms exit the 
market, and gains from increased variety as consumers benefit from access to a wider range of more affordable goods. So called 'new new' trade theories focus on the behavior of heterogeneous firms and show that trade can generate welfare gains through inter-firm reallocation of resources to more productive firms (Melitz). In sum, there is a strong theoretical foundation supporting the linkages between trade and economic growth that accounts for different trade phenomena and points to different mechanisms through which trade can lead to welfare gains.

\subsection{Empirical Studies on Trade and Economic Growth}

Despite the elegance of international trade theory, research on the empirical relationship between trade liberalization and economic growth is not without controversy. Over the 1990s a number of prominent scholars including Dollar and Kraay, Dollar, Sachs et al., and Frankel and Romer used expansive cross-country regressions with various operational definitions of economic openness to demonstrate a positive correlation between economic openness and growth. Their cumulative work is widely credited with providing compelling evidence of the growth-promoting effects of trade openness and contributing to the primacy of liberalization-oriented development strategies in policy communities and international organizations.

A number of other studies, most notably by Harrison and Rodriguez and Rodrik are more skeptical about the growth-promoting effects of trade liberalization. Rodriguez and Rodrik in particular present a powerful critique of the cross-country growth empirics of the 1990s. In reference to the works of Dollar, Sachs and others, Rodriguez and Rodrik contend that "the strong results in this literature arise either from obvious misspecification or from the use of measures of openness that are proxies for other policy 
or institutional variables that have an independent detrimental effect on growth" (315). In a paper for the Overseas Development Council, Rodrik is not only skeptical about the growth effects of trade liberalization, he contends that integration into the global economy likely contributes to income inequality and leaves countries vulnerable to external shocks that can set off conflicts and political instability (13-14). Arguments of this nature have often been espoused by heads of state of developing countries and some parts of the development community and, to an extent, underpin the special and differential provisions for developing countries in the WTO.

While there has been a proliferation of broad-based empirical research on the relationship between economic openness and growth, only a limited number of studies have examined this question in the WTO context. Part of the reason for this is that WTO accession does not occur in a vacuum. It is usually only part, albeit often an important one, of a broader policy shift toward a more market-oriented economy. Therefore, isolating the effects of WTO accession on something as broad and complex as economic growth presents a very daunting methodological challenge. Nevertheless, some notable efforts have been made in this regard.

The primary mechanism through which accession to the WTO, and the trade liberalization it entails, is purported to promote economic growth is through boosting trade. Surprisingly, comparing trade patterns of WTO members to non-members has led some scholars to conclude that GATT/WTO membership has no perceptible tradepromoting effects. See for example Rose. However, in a more nuanced study, Subramanian and Wei differentiated the effects of GATT/WTO membership on different economic sectors and between developed and developing countries, and found evidence 
that GATT/WTO membership promotes trade "strongly, but unevenly". Most pertinent to this paper, Subramanian and Wei found that developing countries that acceded to the WTO following the conclusion of the Uruguay Round, trade roughly 30 percent more than those that acceded earlier (172). Their explanation for this finding is that prior to the completion of the Uruguay round, developing countries were allowed to accede to the GATT without having to undertake meaningful trade liberalization. Building on this finding, Tang and Wei studied the effect of post-Uruguay round accessions on a country's growth trajectory. They found that for those countries required to take substantial reforms, WTO accession resulted in increased growth rates over a five-year period that made the economy 20 percent larger on average than it would have been otherwise. Interestingly, they also found that these effects were stronger in countries with poorer governance, which they interpret as evidence that external policy commitments can serve as a partial substitute for good governance (229). Despite the use of various methodological tools employed to mitigate threats to validity, the authors acknowledge the possibility of an endogeneity bias, in that it is possible that only countries that would independently pursue trade liberalization and market reforms would seek WTO membership. This leads them to conclude that their research "can be seen simply as a new angle to check the consequences of trade reforms for growth" (217).

In the author's view, the challenges in isolating the effects of WTO accession, and economic openness in general, on economic growth should not be taken as a sign that trade liberalization should be abandoned as a growth-promoting policy option. Rather, debates in the literature reflect the complex interplay of factors that affect an outcome as broad as economic growth, and have usefully served to underscore that integration into 
the global economy is but one part of a policy cocktail required for economic growth and development. Chang et al. find empirical support for this view in their work on the importance of what they call "policy complementarities". In cross-country regressions, they interact proxies of educational investment, financial depth, inflation stabilization, public infrastructure, governance, labor market flexibility and ease of firm entry and exit, with a measure of openness and find that the positive effect of trade openness on growth can be greatly enhanced when accompanied by complementary reforms. As a result, trade liberalization should not be seen as a stand-alone, unambiguous and universal determinant of economic growth, but rather as an important contributing factor in a suite of market-oriented reforms that promote competition, economic stability and stable policy intervention. In line with this thinking, WTO accession should not necessarily be seen as an end point, but rather as a useful framework for trade liberalization and a mechanism to lock in the reform process and have it endorsed by the international community. 


\section{HOW COUNTRIES JOIN THE WTO}

While theoretical conceptualizations of international trade negotiations and bargaining power provide useful tools for understanding and analyzing the WTO accession process, actual accession negotiations have not been widely studied. Countryspecific research has focused largely on China, while little is known about the experiences of the 25 other countries that have joined the organization since 1995. Broadbased studies on the accession process are in short supply and limited mostly to working papers and studies commissioned by the World Bank, the International Monetary Fund (IMF), the International Development Research Center (IDRC) and a handful of other international organizations and research institutes. Despite the apparent dearth of research on this topic, some common critiques of the accession process have emerged. The following paragraphs provide a brief review of relevant literature on bargaining power in trade negotiations, an overview of the WTO accession process, and an assessment of some of the main critiques of the accession process, including a specific look at the challenges faced by transition economies.

\subsection{Bargaining Power in International Trade Negotiations}

As discussed in the preceding chapter, WTO negotiations are generally characterized by mercantilist bargaining where governments try to maximize access to foreign export markets while giving up as little as possible in terms of domestic trade liberalization. In the classic model of mercantilist bargaining, negotiating parties trade-off market-access concessions until a final agreement is reached. Since market opening and closure are the currency of mercantilist bargaining, it follows that market size is the dominant force of bargaining power. This concept is borne out in much of the literature 
on multilateral trade negotiations. As Steinberg explains, a promise of market opening or threat of market closure carries more weight when the market in question is large and can engender significant economic and political gains or costs. Furthermore, countries with larger domestic markets have better prospects for internal trade and are thus proportionally less affected (either positively or negatively) by a change in trade access than countries with smaller domestic markets (347).

This line of reasoning is essentially analogous to Bacharach and Lawler's powerdependence theory of international bargaining. They contend that a party's bargaining power is derived from the extent to which other parties depend on it for some type of benefit (e.g., as a key market for export commodities). According to their model, dependence has two key dimensions: 'commitment', or the value of the benefits at stake; and, 'availability' of the benefits at stake from other parties (167). The main implication of this theory is that bargaining power comes from being able to offer something of value to the other party that it cannot obtain from an alternate source. These conceptions of bargaining power and others like them provide a theoretical basis for the widespread anecdotal evidence and commonly held view that developed countries with large economies have the greatest bargaining power in WTO negotiations.

A related consideration that is not widely reflected in the current literature is the extent to which negotiating parties view one another as export competitors in third markets. While this analysis does not necessarily come into play in tariff negotiations, it can be a determining factor in negotiations on WTO rules. For instance, in acceding to the WTO, countries agree to bind and reduce export subsidies and trade-distorting domestic support to agricultural producers. The positions taken by WTO members in 
negotiations on these issues are greatly influenced by their assessment of the extent to which the acceding country is (or has the potential to be) a competitor in their domestic markets and/or an export competitor in third markets. In effect, it was these types of considerations that led many developing countries to concentrate much of their negotiating power on securing reductions in agricultural subsidies in developed countries as an outcome of the Uruguay Round.

In addition to market-based factors, the literature on multilateral trade negotiations highlights some additional sources of bargaining power. In particular, Drahos identifies three additional sources: commercial intelligence networks; enrolment power; and, domestic institutions. A country's commercial intelligence networks comprise the state's trade bureaucracy, business organizations (i.e., industry associations, chambers of commerce, etc.) and individual corporations. Collectively, these groups contribute to the development of effective negotiating strategies by gathering, distributing and analyzing information about the economic performance of the country in question, as well as other negotiating parties (82-83). Although Drahos does not explicitly address this point, in this author's view, the trade bureaucracy's knowledge of international trade rules and experience in trade negotiations can greatly enhance the effectiveness of a country's commercial intelligence networks in shaping negotiating approaches. The concept of enrolment power refers to a country's ability to galvanize other state and nonstate actors into effective negotiating groups or coalitions (83). Particularly in WTO negotiations, coalitions can serve as effective counterweights to countries with large market power. The last source of negotiating power Drahos describes is the internal decision-making rules and delegation of negotiating authority within a country's 
domestic institutions. For example, in some cases, countries can increase their bargaining power by binding negotiators with very narrow mandates. The European Union (EU) also greatly increases its bargaining power by negotiating as a single entity (83).

As implied by Axelrod and Keohane's concept of issue-linkage across multilevel games (239-244), factors beyond the scope of the WTO regime can also serve as a source of bargaining power. To borrow their metaphor, games being played on different chessboards affect one another in international negotiations (239). In the context of multilateral trade negotiations, this means that any number of domestic and international political factors can be used to gain additional bargaining leverage and can affect negotiated outcomes. Although this paper makes the assumption that economic factors are the main determinants of country-behaviour in the WTO, the case studies presented in chapters six, seven and eight shed some light on the role of political factors.

\subsection{The WTO Accession Process}

Accession negotiations take place on two parallel tracks: multilateral and bilateral. During the multilateral negotiations, a working party composed of interested WTO members examines the acceding country's economic and trade regime to identify inconsistencies with WTO obligations and to ascertain what changes are required to achieve conformity with WTO rules. Progress depends on those changes, as reflected in the transparency, accuracy, and detail provided by the applicant in response to questions tabled by working party members. The report of the working party serves as the focal point for this process. It describes an applicant's trade policy regime, summarizes key working party discussions and sets out an acceding country's eventual commitments on WTO rules. Over the course of a country's accession negotiations, working party 
members hold regular formal meetings to review progress on the report of the working party. In areas where particular efforts are required to bring a country's trade regime into line with WTO obligations, plurilateral meetings among experts are held to help advance the progress of the working party. Some of the most common trade topics for which plurilateral meetings are required include subsidies to agricultural producers, sanitary and phytosanitary measures (SPS) and technical barriers to trade (TBT). In addition to plurilateral meetings, countless informal or small group meetings take place among the key players on any given issue. Thus, while formal working party meetings help to guide the accession process, much of the 'nuts and bolts' or technical work of the negotiations actually takes place at the plurilateral and informal levels.

In parallel with multilateral deliberations, interested working party members hold bilateral market-access negotiations with the acceding country. During these negotiations, working party members focus on securing the reduction or elimination of tariffs and nontariff barriers affecting market-access for goods and services. In keeping with the MFN principle, an acceding country's bilateral commitments are applied equally to all WTO members upon completion of the accession process. Once both the multilateral and bilateral negotiations have concluded, the working party finalizes the terms of accession. These appear in the Working Party Report, a draft membership treaty ("Protocol of Accession") and lists ("Schedules") of the acceding member's commitments. The final package is presented to the WTO General Council or the Ministerial Conference. If twothirds of WTO members vote in favour, the applicant is free to sign the protocol and to accede to the organization. Accession occurs thirty days after the acceding country notifies the WTO that it has ratified the Protocol of Accession. 
WTO accession negotiations differ from the classic model of mercantilist bargaining in that they are inherently one-sided because the 'concessions' of WTO members are pre-determined in the form of their existing WTO commitments. In other words, applicant countries already know what benefits they will receive from WTO membership. As a result, negotiations focus solely on determining the price an applicant has to pay (in terms of trade liberalization and commitments on WTO rules) to gain access to the club benefits that come with WTO membership. Geneva-based negotiators often describe the process as WTO members each extracting the requisite "pound of flesh" from acceding countries. Because of the one-sided nature of the accession process, trade-offs occur not between negotiating parties, but among different market-access concessions or commitments on rules. For example, an acceding country may agree to significant tariff reductions on imported automobiles provided that it is allowed to maintain higher tariffs on imported textiles.

\subsection{Critiques of the WTO Accession Process}

Despite the steady expansion in WTO membership since 1995, the accession process has not been impervious to criticism. In particular, many observers have complained that the open-ended nature of the accession process has allowed WTO members to wield too much bargaining power over applicant countries resulting in an unfair and overly taxing process. Commentary of this nature was summarized succinctly at the 2006 WTO Public Forum during a session organized by the IDRC entitled, 'Improving the Accession Process for the $21^{\text {st }}$ Century.' Participants in the session identified three main critiques of the accession process: 
(1) The complexity of negotiations is high and growing, and as result, negotiations are taking longer to complete and have a higher financial cost;

(2) The price of accession (in terms of trade liberalization) is high and rising; and,

(3) The price of accession frequently includes members taking on so-called

'WTO-plus' commitments and 'WTO-minus' rights (Evenett).

In support of the criticism that WTO accession negotiations are becoming more complex and taking longer to complete, Evenett cites a trend increase in the amount of time required to accede to the WTO from roughly 40 months for the fifth accession to 120 months for the twentieth accession (2). Langhammer and Lucke (6-7) note that the growing complexity and length of negotiations can present serious resource challenges for developing countries, especially least developed countries (LCDs), which often have limited government budgets and limited numbers of highly skilled personnel. In particular, they emphasize the significant opportunity cost of dedicating highly skilled labour to WTO accession negotiations over a period of many years when it could otherwise be engaged in productive domestic activities including work in the private sector. Cattaneo and Braga offer a number of explanations for this trend. Most persuasively, they point out that as more countries join the WTO, each prospective member will be subjected to an increasing number of specific requests for market-access concessions and greater overall negotiating demands, reflecting the ever-widening interests of the existing membership. Cattaneo and Braga also note that remaining accession candidates are comprised largely of countries that have faced or are currently facing a number of challenges including political instability, conflict, poverty, geographical isolation and/or transition from a centrally-planned economy. These 
challenges make it all the more difficult and time consuming for the countries in question to implement the legislative and regulatory changes required for WTO accession (13-15).

On the assertion that the price of WTO accession is 'high and rising', evidence is mixed. Evenett and Braga find that the average tariff bindings for developing countries that have acceded to the WTO have declined over time, and are now lower than those agreed in the Uruguay round for both agricultural and industrial products (233-234). In contrast, by looking at applied tariffs rather than bound tariffs, Drabek and Bacchetta find that many acceding countries are not required to make unreasonable tariff cuts upon accession. They observe that many acceding countries, particularly former Soviet Union members, engage in unilateral trade liberalization in the lead up to their accession and are thus able to negotiate the terms of their WTO membership largely within the scope of pre-existing reforms (1092-1093). With respect to commitments on services, Evenett and Braga report that countries that have acceded to the WTO since 1995 have taken commitments in an average of 105 service sub-sectors, whereas the averages for the Uruguay round were 20,44 and 108 respectively for LDCs, developing countries and developed countries. However, the authors themselves note that the number of service sub-sector commitments is a very crude proxy for the price of accession as it ignores the depth and breadth of liberalization in each sub-sector (235).

On the issue of WTO rules, there has been some controversy over the extent to which acceding countries have taken on commitments that go beyond the Uruguay round (WTO-plus) and have forgone rights maintained by other WTO members (WTO-minus). As Evenett and Braga and others have observed, there can be no definitive answer to this question because the determination of a commitment as being WTO-plus or WTO-minus 
often depends largely on the interpretation of the relevant WTO agreements (235). Nevertheless, there is a general consensus that some countries have taken accession commitments upon accession that would seem to go beyond the spirit of the Uruguay Round agreements. As an example, China agreed to export quotas on apparel for five years beyond the date of accession, even though the multi-fibre agreement was phased out during the Uruguay round. ${ }^{4}$ Aside from questions around the "fairness" of some WTO members taking on more commitments than others, many authors have pointed out that since WTO-plus commitments are typically within the spirit of trade liberalization and seek to strengthen multilateral disciplines, they should help governments to adopt more efficient policies and help to boost trade and investment (Cattaneo and Braga 21).

While the critiques assessed in the preceding paragraphs have certainly pointed to some interesting areas for additional study, this author takes the view that the unique economic and political context of each WTO accession, and the built-in flexibility of the negotiations, make it very difficult to draw definitive conclusions about the WTO accession process solely on the basis of broad-based empirical studies. While there is some evidence that the 'price' of accession may be rising, the quantitative research methods employed to date have largely failed to account for the broader economic context in which WTO accession occurs. As a result, while we know that the average tariff bindings of new members are increasingly low, and now lower than those of comparable countries at the conclusion of the Uruguay Round, we cannot say with confidence that this reflects an increasing 'price' of accession, or members placing excessive demands on acceding countries. While this may be true in some cases, it would

\footnotetext{
${ }^{4}$ An illustrative list of WTO-plus and WTO-minus commitments taken by acceding countries can be found in Cattaneo and Braga (19-20)
} 
need to be evaluated on a country-by-country basis as is undertaken in the case study section of this paper. Also, it is worth keeping in mind that if the price of accession were too high, countries would not be joining the WTO every year, and there would not be 30 countries currently seeking membership. What can be said with certainty is that accession negotiations are becoming increasingly complex and are requiring more and more time, energy and resources. To a great extent, this complexity may be inevitable. The WTO Agreements are very broad in scope and much more comprehensive than the GATT in that they cover trade in services, intellectual property rights, and trade related investment measures. However, in so much as the accession process creates resource demands that are excessively challenging for some acceding countries, this trend can be seen as negatively affecting the real or perceived inclusiveness of the organization.

Partially in response to some of the critiques of the accession process described above, the WTO General Council adopted special guidelines for LDC accessions in December 2002. These guidelines were designed to ease the integration of LDCs into the multilateral trading system and contain provisions related to market-access, WTO rules, process, and trade-related technical assistance and capacity building. With respect to market-access, WTO members are asked to "exercise restraint in seeking concessions and commitments on trade in goods and services from acceding LDCs, taking into account the levels of concessions and commitments undertaken by existing WTO LDC Members". Likewise, acceding LDCs are expected to offer "concessions and commitments on goods and services commensurate with their individual development, financial and trade needs" [emphasis added]. In the area of WTO rules, the guidelines stipulate that special and differential treatment, as set out in relevant WTO legal instruments, shall be 
applicable to all acceding LDCs and provide that "transitional periods/transitional arrangements ... shall be granted in accession negotiations taking into account individual development, financial and trade needs". Finally, the guidelines also specify that "commitments to accede to any of the WTO plurilateral trade agreements or to participate in other optional sectoral market-access initiatives shall not be a precondition for accession to the Multilateral Trade Agreements of the WTO" (WTO "Handbook on Accession"). Taken as a whole, these guidelines create a unique institutional framework for LDC accessions that is considerably more flexible and generally less demanding of LDCs in terms of trade liberalization.

\subsection{Transition Economies}

Transition economies, that is countries in the process of shifting from a centrallyplanned to a market-based economic system, are another group that face some unique challenges in the accession process. For such countries, WTO membership is commonly viewed as vital to integration into the global economy - it serves as a catalyst and platform for domestic reform, provides improved access to major export markets, and gives recourse to binding dispute settlement (Michalopoulos 1-5). For these reasons, the accession process can be a focal point of the transition from a centrally planned to a market economy. Aligning domestic laws with WTO rules usually involves significant institutional and legal reforms that fundamentally change the role of the state in the economy and disassemble previous channels of economic interaction. Changes of this magnitude challenge established power structures and entrenched interests groups, and in consequence can be deeply politically divisive. As a result, many transition economy accessions have been significantly delayed by wavering political will. 
This political obstacle can be exacerbated by any number of more practical challenges. As with many LDCs, transition economies are frequently short on the human and material resources to engage effectively in the negotiating process. Government officials often have little or no experience with multilateral trade negotiations and sometimes lack familiarity with the basic underlying legal and economic concepts. Institutional weaknesses in applicant countries can make it difficult for implicated ministries to coordinate effectively, gather required information and communicate with WTO members in a timely and coherent fashion. Further, the broad scope of required reforms can lead to difficult and lengthy legislative processes. In order to address some of these issues, many transition economies have sought funding for capacity building in trade policy and international negotiations from a variety of donors including the WTO itself, various member-states, and other multilateral organizations such as the World Bank (Michalopoulos 16-18). In many cases, such training initiatives have been critical in helping applicant countries develop the necessary knowledge and skills to complete the accession process. These themes are addressed in more detail throughout the case studies presented in chapters six and seven. 


\section{METHODOLOGY}

This paper uses both quantitative and qualitative research methods to explore the relationship between the independent variables - the size of an acceding country's economy, the value of its trade flows and its trade diversity - and the two dependent variables - the degree of scrutiny to which a country's trade policies are subjected during accession negotiations and the degree of trade liberalization required of a country, as embodied in its WTO commitments. In order to evaluate whether or not a relationship exists among these variables, it is first necessary to establish operational definitions for each. These definitions are explained below and summarized in tables 4(a) and 4(b).

\subsection{Dependent Variables}

The two dependent variables are designed to capture the characteristics of the negotiating process and its outcomes. The first dependent variable is the degree of scrutiny to which an acceding country's trade policies and practices are subjected during the accession process. This variable is assessed based on three measures of the interest, engagement and investment of WTO members in the negotiations. These measures are: the number of members of the working party, the number of working party meetings, and the length of the report of the working party. In each case, some further explanations are warranted.

Since participation in a WTO accession working party is voluntary, the number of working party members should provide a general indication of WTO members' interest and engagement in a particular accession. However, simply being a member of the working party does not necessarily imply an investment of significant resources (both human and financial), or a rigorous negotiating effort. To address this possible pitfall, 
two additional measures are employed. The first measure is the total number of formal working party meetings, calculated as the number of days on which a meeting was held. The second measure is the page length of the report of the working party, including annexes. Together, these two measures are designed to give a more accurate picture of the negotiating rigour of the working party. A tabulation of the total number of formal working party meetings has a considerable advantage over the more commonly used measure of elapsed time between the date of application and the date of WTO accession (typically counted in months). This latter measurement is more susceptible to being skewed by broad political and economic factors outside the accession process (i.e., elections, political instability, conflict, economic crises and inertia) that can cause significant time lapses between working party meetings. However, referring back to chapter three on the WTO accession process, it should be underscored that many of the more technical and sensitive aspects of the negotiations are addressed plurilaterally or even informally among small groups of key working party members. Therefore, the number of formal working party meetings should only be seen as a rough proxy for the overall efforts of the working party. The length of the report of the working party is a useful complementary measure that partially addresses this methodological limitation. The report of the working party is essentially a summary of the deliberations between members and the acceding country. The report incorporates key dialogue from formal working party meetings, but also draws from plurilateral meetings and written exchanges, and reflects discussions that take place outside of the formal working party process. In this sense, the length of the report serves as a relatively good proxy for the overall negotiating effort of the working party. 
The three measures described above (number of working party members, number of working party meetings, and length of the working party report) are combined to give an overall score for the degree of negotiating scrutiny. The overall score is calculated as the sum of the numerical values for each of these measures. A higher score indicates that a country's trade policies were subjected to a higher degree of negotiating scrutiny during accession negotiations. A lower score indicates the opposite.

There are two potential confounding variables inherent in the first part of this operational definition (i.e. number of working party members) that must be addressed. The first such variable can generally be labelled as 'politics'. Although the WTO is an inherently economic organization, there is no doubt that the decisions and negotiating positions of its members are often greatly shaped by both domestic and international politics. However, with respect to the WTO accession process, the major political decision whether or not to accept a prospective member's application to accede to the organization and then to establish a working party is made at the outset. Thus, once a working party has been established, the decisions on the part of existing WTO members to join the working party (or not) are motivated predominantly by economic considerations and are generally procedural in nature, and neither highly contentious nor politically charged. Thus, this possible source of bias should not pose a significant threat to the internal validity of this study. The second possible confounding variable is the date of accession. As 25 countries have acceded to the WTO since 1996, a country that joined in 2011 could have up to 25 more countries participate in its working party than a country that joined in 1996. To account for this potential source of bias, countries that acceded to the WTO after 1996 are excluded from the final tabulation of working party members. 
The second dependent variable, the extent of trade liberalization, is also measured in three ways: first, as an acceding country's average final bound tariff; second as the number of commitment paragraphs in the working party report; and third, as the number of specific service sub-sector commitments in the service schedule. Although each of these measures benefits from being easily quantifiable, for various reasons explained below, they can also justly be described as somewhat crude. This, in effect, reflects the inherent trade-off in almost any quantitative research in political science. Thus, in the author's view these three measures, while by no means infallible, are sufficient to give a general indication of the relative scope of a country's WTO commitments and the resultant trade liberalization. The results of the quantitative analysis should be taken in this light.

The major pitfall associated with using average final bound tariff levels as the basis for comparison among WTO members is that it does not capture the magnitude of tariff liberalization undertaken by an acceding country, only its end result. For instance, both Moldova and Albania have average final bound tariffs of seven percent. However, without knowing the pre-WTO accession average applied tariffs for each country, it is impossible to tell whether one underwent deeper tariff cuts than the other. Unfortunately, as alluded to in chapter three, a "before and after" research design that would attempt to address this issue by comparing pre-and post-accession tariff rates would also suffer from serious methodological weaknesses. In particular, many countries join the WTO in the context of broader economic reform efforts that involve various trade liberalizing measures including tariff reductions. As a result, the terms of accession are often negotiated within the scope of pre-existing reforms. From a methodological perspective, 
this could render a strictly quantitative comparison of pre-and post-accession tariff levels misleading. Notwithstanding the limitations of comparing average final bound tariffs, the importance of tariff bindings as part of an acceding country's WTO commitments should not be understated. A common practice in accession negotiations is for WTO members to, at a minimum, ask applicant countries to bind their tariffs rates at the applied levels. While this type of tariff binding has no immediate liberalizing impact, the overall transparency, predictability and stability that it brings to a country's tariff regime can be an important contributing factor to the development of a more business-friendly environment.

Much in the same way that comparing tariff bindings has some limitations, tabulating commitment paragraphs and specific service sub-sector commitments misses some of the important nuances and technical details that can be so pivotal in trade negotiations. For instance, nearly all working party reports contain at least one commitment paragraph pertaining to trade-related investment measures (TRIMS). While some require the acceding country to abide by the provisions of the WTO Agreement on TRIMS upon accession, others may provide flexibility in the form of phase-out periods. Similar examples exist with respect to commitments on specific service sub-sectors. Nevertheless, it stands to reason that in general terms more commitment paragraphs and more commitments on specific service sub-sectors should equate to more trade liberalization. As was the case with negotiating scrutiny, the three measures described above are combined to give an overall score for the degree of trade liberalization. This overall score is calculated as the average final bound tariff rate subtracted from the sum of the number of commitment paragraphs and the number of commitments on specific 
services sub-sectors. ${ }^{5}$ A higher score indicates more trade liberalization. A lower score indicates the opposite.

Table 4(a) - Operational Definitions of Dependent Variables

\begin{tabular}{|c|c|}
\hline Dependent Variables & Definitions \\
\hline $\begin{array}{l}\text { (1) Negotiating } \\
\text { Scrutiny }\end{array}$ & $\begin{array}{l}\text { Number of working party members } \\
\text { Number of working party meetings in days } \\
\text { Length of the report of the working party, including annexes, in days }\end{array}$ \\
\hline $\begin{array}{l}\text { (2) Trade } \\
\text { Liberalization }\end{array}$ & $\begin{array}{l}\text { Average final bound tariff rate } \\
\text { Number of commitment paragraphs in the report of the working party } \\
\text { Number of specific services sub-sector commitments }\end{array}$ \\
\hline
\end{tabular}

\subsection{Independent Variables}

The independent variables - economy size, trade value and trade diversity - are designed to reflect different characteristics of an acceding country's economy that could influence the degree of interest and engagement from WTO members in its accession negotiations, as well as the degree of trade liberalization required to join the WTO. This paper hypothesizes that WTO members invest greater resources in negotiations that are of greater economic consequence to them. This results in more negotiating scrutiny and more trade liberalization for countries with large economies and large, diverse trade profiles. This hypothesis is derived from Dymond and Hart's concept of mercantilist bargaining wherein governments see foreign market opening and the resultant export opportunities as a political gain and domestic market opening and the resultant import competition as a cost. Given the finite resources countries dedicate to accession negotiations, WTO members seek to maximize economic and political gains by investing

\footnotetext{
${ }^{5}$ The average final bound tariff rate is subtracted from the sum of the other measures because higher tariffs are indicative of less liberalization, while a higher number of commitments on WTO rules and specific service sub-sectors is indicative of more trade liberalization. Thus, using this methodology, a higher average final bound tariff will reduce the overall trade liberalization score more than a lower average final bound tariff.
} 
more heavily in negotiations that are of greater economic consequence. A competing hypothesis is that larger acceding countries are able to use their economic size to their advantage in the negotiating process and thereby more effectively withstand and counteract pressure from WTO members to undergo trade liberalization. This hypothesis is also premised on the concept of mercantilist bargaining, but draws more specifically on theories of bargaining power in multilateral trade negotiations. The concepts of market power and commercial intelligence networks are particularly relevant to this hypothesis in that countries with larger economies that trade more are likely to benefit from more of both.

The size of a country's economy is the most basic independent variable and, for the purpose of this study, is measured as a country's gross domestic product (GDP) in US dollars in the year it acceded to the WTO. The value of a country's trade flows is a more nuanced measure designed to more closely reflect the importance of an acceding country to the international trading system. The value of a country's trade flows is calculated as the sum total value of imports and exports in US dollars in the year of accession. The assumption inherent in this independent variable is that acceding countries that trade more will generate more interest and engagement among existing WTO members. The value of both imports and exports is taken into account based on the notion that existing WTO members consider three main factors when assessing how much to invest in a given negotiation: the acceding country's value or potential value as an export market; the acceding country's role or possible role as an export competitors in third markets; and, the acceding country's role or possible role as a competing supplier in the domestic market. 
The third and most nuanced measure also reflects trade value, but adds a dimension of trade diversity. This measure is calculated as the sum total of product categories, measured at the two-digit level according to the 2007 Harmonized Commodity Description and Coding System (Harmonized System or HS in short form), for which the value of total trade (i.e., exports plus imports) is equal to or greater than US $\$ 100$ million in the year of accession. Although this threshold is somewhat arbitrary, in the author's view, it allows for meaningful analysis. It is small enough to capture even relatively modest differences in trade value and diversity between some of the smaller countries that have joined the WTO in recent years. At the same time, the threshold is large enough to reasonably expect that the economic differences it reflects could have been perceived and taken into consideration by existing WTO members during accession negotiations. This measure is designed to account for countries where trade values are high, but concentrated in a single commodity, oil for example. In this case, the underlying assumption is that the accession of a country with a less diversified trade profile would garner less attention than the accession of a country with a similar trade value, but greater trade diversity. For example, while a wealthy oil-producing country may be a valuable market for exporters from some WTO members, the concentration of its exports in a single commodity would greatly limit the extent to which WTO members would view it as an export-competitor. This, in turn, could have a limiting effect on the extent of their interest and engagement in accession negotiations. 
Table 4(b) - Operational Definitions of the Independent Variables

\begin{tabular}{l|l}
\hline Independent Variables & Definitions \\
\hline (1) Economy Size & $\begin{array}{c}\text {. GDP in US dollars in the year of accession } \\
\text { - Sum total of value of exports and imports in US dollars in } \\
\text { the year of accession }\end{array}$ \\
\hline (2) Trade Value & $\begin{array}{l}\text { Sum total of product categories at the HS 2-digit level for } \\
\text { which the total trade (i.e., exports plus imports) is equal to or } \\
\text { exceeds US\$ one hundred million in the year of accession }\end{array}$ \\
\hline (3) Trade Diversity &
\end{tabular}

\subsection{Quantitative Analysis}

The quantitative dimension of this paper seeks to establish some baseline relationships between the dependent and independent variables based on a broad level analysis of the 22 developed and developing country accession negotiations that have been concluded since 1996 . The numerical values associated with negotiating scrutiny and trade liberalization are assessed against economy size, trade value and trade diversity using the Pearson product-moment correlation coefficient (PCC) and the Spearman rank correlation coefficient. The PCC is the measure most commonly used to describe the strength of a linear relationship between two variables. In other words, the resulting correlation coefficient gives a good indication of the extent to which changes in one variable influence a second variable. The Spearman's rank correlation coefficient (Spearman's rho) is a related measure calculated using ordinal data rather than interval data. In other words, whereas the PCC measures the dependence between two sets of raw data, the Spearman's rho coefficient measures dependence between two sets of ranked data. Although each measure is considered relatively robust, Spearman's rho is less susceptible to the effects of outliers and other forms of non-normality in distributions. 
As explained in detail in the previous chapter, LDCs are subject to special accession guidelines that ask WTO members to exercise restraint in seeking marketaccess concessions and give consideration to an acceding country's individual development, financial and trade needs. In the author's view, these guidelines create a separate and distinct institutional setting for LDC accessions, which results in LDCs being systematically subjected to less scrutiny throughout the accession process and being required to undergo a lesser degree of trade liberalization relative to non-LDCs. For this reason, and notwithstanding the fact that there is much interesting research that could be done on the topic of LDC accessions, these countries are excluded from the scope of this paper.

\subsection{Qualitative Analysis}

The qualitative research involves a three-part case study. The first part compares the WTO accessions of Kyrgyzstan, Ukraine and Russia (chapter six). The second part compares the WTO accessions of Mongolia, Vietnam and the China (chapter seven). These six countries, comprising the first two parts of the case study, represent a reasonable cross section of WTO accessions in that two can be considered 'small economies', two can be considered 'medium-sized economies' and two can be considered 'large economies'. The selection of three eastern and central European transition economies and three Asian transition economies reflects an attempt to isolate the effects of economy size, trade value and trade diversity from broader social, political and economic factors that could bear influence on accession negotiations. This sampling also reflects an effort to maximize policy-relevance as eight of the 18 developed and 
developing countries currently seeking to accede to the WTO can be characterized as transition economies.

A possible source of the bias in this sample is that all of the countries are transition economies. As we have seen, transition economies face some unique challenges in the accession process. In particular, the need for broad institutional and structural reform and the frequent lack of experience with international trade rules and negotiations can be significant barriers. When examined in terms of sources of negotiating power, the accession efforts of transition economies may be hampered by weak or practically non-existent commercial intelligence networks. In order to address this possible source of bias, the third part of the case study presents a brief review of the accession negotiations of Jordan and Saudi Arabia (chapter eight). This chapter is intended to serve as a methodological check to test that research findings are applicable to WTO accessions of non-transition economies.

The case studies are designed to complement and build on the quantitative research findings by providing an in-depth review of each country's accession, focusing both on the negotiating process itself and its outcomes. Case studies explore the accepted narratives around each of the negotiations, including an examination of any key points of contention and how they were resolved. In addition, each case study presents an analysis of the most significant WTO commitments of the country in question. This work draws from existing research, media reports, official records and other information sources. The case study on Russia's WTO accession, in particular, draws heavily from the author's professional experience accumulated over five years as the senior trade policy analyst responsible for WTO accession negotiations at Agriculture and Agri-Food 
Canada (AAFC). This experience includes representing AAFC at a number of working party meetings and plurilateral meeting in Geneva, as well as countless other negotiating sessions in Ottawa, Geneva and Moscow. 


\section{BASELINE DATA}

This chapter presents basic findings on the relationship between the dependent and independent variables. The data on which the analysis is based can be found in Tables 5(a) and (d). Unless otherwise specified, information in these tables can be found in the acceding country's WTO accession protocols, including the Report of the Working Party and the Schedule of Specific Commitments on Services. These documents are publicly available through the WTO website's accessions gateway. Tables 5(b), (c), (e) and (f) summarize research findings.

Before examining the results, it is worth recalling the main hypothesis put forth in this paper: acceding countries with larger economies, higher trade values and more diverse trade profiles are subjected to greater negotiating scrutiny from existing WTO members resulting in greater trade liberalization. This occurs because existing members invest more resources in negotiations that are of greater economic consequence. A competing hypothesis is that larger acceding countries are able to use their market size to their advantage in the negotiating process and thereby resist pressure to undergo trade liberalization.

\subsection{Economy Size, Trade Value, Trade Diversity and Negotiating Scrutiny}

A cursory review of Table $5(a)$ is enough to recognize that there are positive correlations between each of economy size, trade value and trade diversity and negotiating scrutiny. 
Table 5(a) - Economy Size, Trade Value, Trade Diversity, and Negotiating Scrutiny (Monetary values in US\$ billions)

\begin{tabular}{|c|c|c|c|c|c|c|c|}
\hline Country & $\begin{array}{l}\text { GDP in } \\
\text { the Year } \\
\text { of WTO } \\
\text { Accession }\end{array}$ & $\begin{array}{l}\text { Total } \\
\text { Trade } \\
\text { Value in } \\
\text { the Year } \\
\text { of } \\
\text { Accession }\end{array}$ & $\begin{array}{l}\text { Trade } \\
\text { Diversity } \\
\text { in the } \\
\text { Year of } \\
\text { Accession }\end{array}$ & $\begin{array}{c}\text { Number } \\
\text { of } \\
\text { Working } \\
\text { Party } \\
\text { Members }\end{array}$ & $\begin{array}{c}\text { Number } \\
\text { of } \\
\text { Working } \\
\text { Party } \\
\text { Meetings }\end{array}$ & $\begin{array}{c}\text { Length of } \\
\text { the } \\
\text { Report of } \\
\text { the } \\
\text { Working } \\
\text { Party } \\
\text { (pages) }\end{array}$ & $\begin{array}{l}\text { Overall } \\
\text { Negotiating } \\
\text { Scrutiny }\end{array}$ \\
\hline 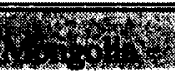 & 8 & (2) & & & & & \\
\hline 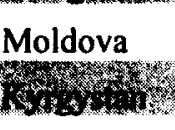 & $\begin{array}{l}1.5 \\
1.6\end{array}$ & 1.5 & 3 & 18 & 5 & 83 & 106 \\
\hline $\begin{array}{l}\text { Armenia, } \\
\text { Republic of } \\
\end{array}$ & 2.8 & Wh & 2 & 20 & 6 & 80 & 106 \\
\hline Albania & 3.8 & 1.4 & 3 & 14 & 10 & 75 & 99 \\
\hline Estonia & 5.7 & 5.8 & 13 & 20 & 9 & 47 & 76 \\
\hline Jordan & 8.5 & 6.5 & 18 & 30 & 5 & 69 & 104 \\
\hline Panama & 10.1 & 3.6 & 9 & 32 & 5 & 31 & 68 \\
\hline Oman & 19.9 & 15.9 & 13 & 29 & 6 & 50 & 85 \\
\hline Ecuador & 21.3 & 8.6 & 18 & 22 & 14 & 47 & 83 \\
\hline Ukraine & 180.4 & 152.5 & 47 & 32 & 25 & 237 & 294 \\
\hline Saudi & 315.6 & 240.2 & 64 & 47 & 20 & 135 & 202 \\
\hline Russia & 1477 & 560 & 85 & 48 & 42 & 604 & 694 \\
\hline
\end{tabular}

Note: In cases where relevant data in the year of accession is not available, the closest year for which data is available is used.

Sources of Economic and Trade Data: United Nations Global Indicators Database, Global Trade Atlas and Economy Watch Database (for Chinese Taipei). 
This initial impression is supported by quantitative research findings. Although the criteria for interpreting the size of a correlation can vary greatly depending on the context, in the social sciences correlation coefficients between (-)0.5 and (-)1.0 are generally considered to be large, while coefficients between (-)0.3 and (-)0.5 are considered to be medium sized. Coefficients between (-)0.1 and (-)0.3 and between $(-) 0.0$ and (-)0.09 are considered small and statistically insignificant respectively. The PCCs between economy size, number of working party members, number of working party meetings and length of the report of the working party are $0.774,0.914$ and 0.788 respectively. In line with these findings, the correlation coefficient between economy size and overall negotiating scrutiny is 0.835 . Similarly, the PCC's between trade values in the year of accession, number of working party members, number of working party meetings, length of the report of the working party and the overall scrutiny score are $0.872,0.923,0.784$ and 0.841 respectively. Finally, PCCs between trade diversity in the year of accession and these same measures are $0.915,0.824,0.653$ and 0.720 respectively. These findings are summarized below in table 5(b).

Table 5(b) - Pearson Product-Moment Correlation Coefficients for Negotiating Scrutiny

\begin{tabular}{|c|c|c|c|c|c|}
\hline & & $\begin{array}{c}\text { Number of } \\
\text { Working } \\
\text { Party } \\
\text { Members }\end{array}$ & $\begin{array}{l}\text { Number of } \\
\text { Working } \\
\text { Party } \\
\text { Meetings }\end{array}$ & $\begin{array}{l}\text { Length of the } \\
\text { Report of the } \\
\text { Working } \\
\text { Party } \\
\text { (pages) }\end{array}$ & $\begin{array}{l}\text { Overall } \\
\text { Negotiating } \\
\text { Scrutiny }\end{array}$ \\
\hline 86) & Economy Size & 0.774 & 0.914 & 0.788 & 0.835 \\
\hline 8 & Trade Value & 0.872 & 0.923 & 0.784 & 0.841 \\
\hline & $\begin{array}{l}\text { Trade } \\
\text { Diversity }\end{array}$ & 0.915 & 0.824 & 0.653 & 0.720 \\
\hline
\end{tabular}


The results of the Spearman's rho test tell a similar story, with correlation coefficients being somewhat lower. but still within the range of what can be considered large. The coefficients between economy size, trade value and trade diversity and overall negotiating scrutiny are $0.594,0.672$ and 0.633 . Detailed findings are presented in table 5(c).

Table 5(c) - Spearman Rank Correlation Coefficients for Negotiating Scrutiny

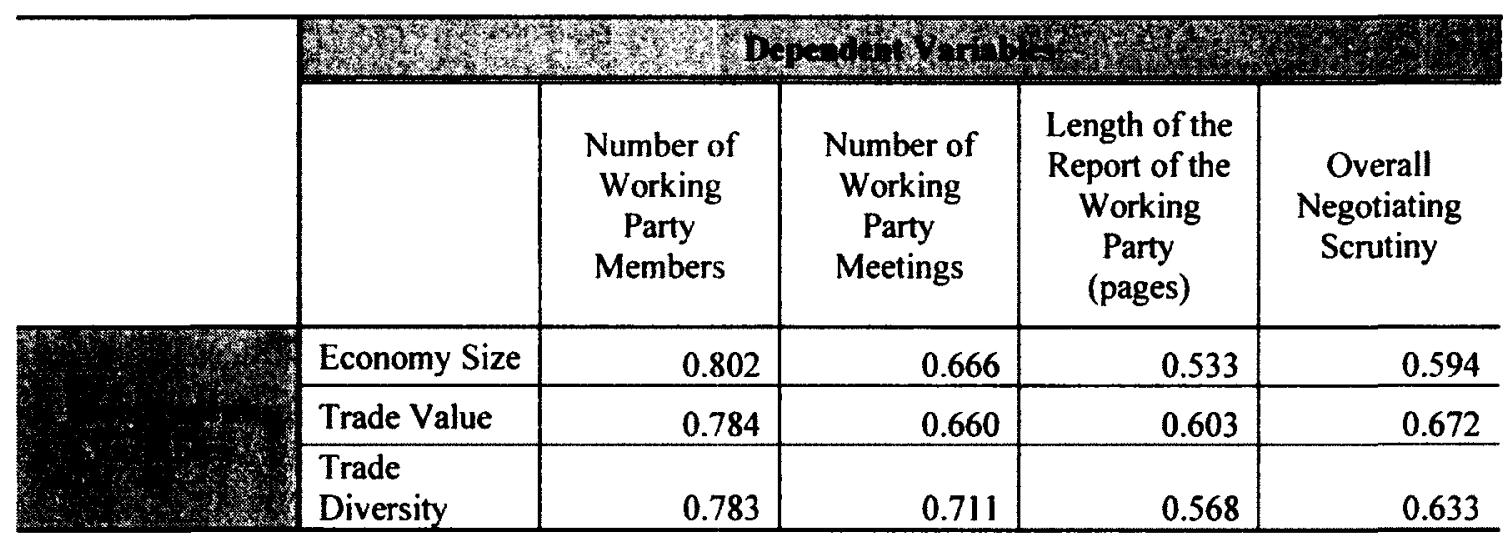

The somewhat weaker correlations between the ordinal data sets (measured by Spearman's rho) relative to the interval data sets (measured by PCC) likely reflect the influence of outliers on the latter. As can be seen in table 5(a), some of the measures recorded for China and Russia in particular are quite numerically distant from the remainder of the data set. Outliers do not exist with the Spearman's rho because raw data is converted to rank data. Thus, for the present data set, Spearman's rho is the more robust measure and likely produces results that more accurately reflect the strength of the relationship between the dependent and independent variables.

In summary, according to both measures of statistical correlation, the independent variables seem to have relatively strong predictive power over various measures of negotiating scrutiny. Thus, we can say with some confidence that the larger a country's 
economy and the more it trades, across a greater range of product categories, the more negotiating scrutiny its trade policies and practices are subjected to during the accession process. This finding strongly supports the first part of the main hypothesis put forth in this paper and suggests that WTO members do indeed seek to maximize value by dedicating more resources to accession negotiations that are more economically consequential.

\subsection{Economy Size, Trade Value, Trade Diversity and Trade Liberalization}

With respect to the relationship between the independent variables and trade

liberalization, the picture is much less clear. The relevant raw data is presented in Table $5(d)$.

Table 5(d) - Economy, Size, Trade Value, Trade Diversity, and Trade Liberalization (Monetary values in US\$ billions)

\begin{tabular}{|c|c|c|c|c|c|c|c|}
\hline Country & $\begin{array}{l}\text { GDP in } \\
\text { the Year } \\
\text { of WTO } \\
\text { Accession }\end{array}$ & $\begin{array}{l}\text { Total } \\
\text { Trade } \\
\text { Value in } \\
\text { the Year } \\
\text { of } \\
\text { Accession }\end{array}$ & $\begin{array}{l}\text { Trade } \\
\text { Diversity } \\
\text { in the } \\
\text { Year of } \\
\text { Accession }\end{array}$ & $\begin{array}{c}\text { Average } \\
\text { Final } \\
\text { Bound } \\
\text { Tariff } \\
\text { (ad } \\
\text { valorem) }\end{array}$ & $\begin{array}{l}\text { Number of } \\
\text { Commitment } \\
\text { Paragraphs } \\
\text { in the } \\
\text { Working } \\
\text { Party Report }\end{array}$ & $\begin{array}{c}\text { Number of } \\
\text { Specific } \\
\text { Commitments } \\
\text { on Service } \\
\text { Sub-Sectors }\end{array}$ & $\begin{array}{c}\text { Overall } \\
\text { Trade } \\
\text { Liberalization }\end{array}$ \\
\hline Moldova & 1.5 & 1.5 & 3 & 7 & 28 & 131 & 152 \\
\hline $\begin{array}{l}\text { Armenia, } \\
\text { Republic of }\end{array}$ & 2.8 & 1.9 & 2 & 8.5 & 39 & 106 & 136.5 \\
\hline Albania & 3.8 & 1.4 & 3 & 7 & 29 & 108 & 130 \\
\hline Estonia & 5.7 & 5.8 & 13 & 5.5 & 24 & 103 & 121.5 \\
\hline Jordan & 8.5 & 6.5 & 18 & 16.3 & 29 & 110 & 122.7 \\
\hline Panama & 10.1 & 3.6 & 9 & 23.5 & 24 & 63 & 63.5 \\
\hline Oman & 19.9 & 15.9 & 13 & 13.8 & 26 & 98 & 110.2 \\
\hline
\end{tabular}




\begin{tabular}{|c|c|c|c|c|c|c|c|}
\hline Ecuador & 21.3 & 8.6 & 18 & 21.7 & 21 & 66 & 65.3 \\
\hline \multicolumn{8}{|c|}{ 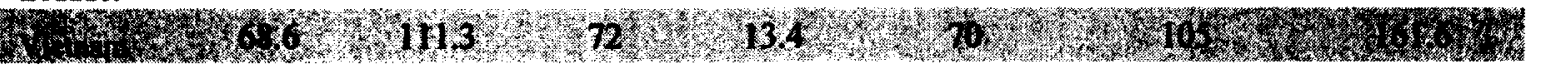 } \\
\hline Ukraine & 180.4 & 152.5 & 47 & 5.8 & 63 & 137 & 194.2 \\
\hline & & 2434 & & & & & \\
\hline $\begin{array}{l}\text { Saudi } \\
\text { Arabia }\end{array}$ & 315.6 & 240.2 & 64 & 11.8 & 59 & 120 & 167.2 \\
\hline & & & & & 163 & 116 & 2868 \\
\hline Russia & 1477 & 560 & 85 & 7.8 & 163 & 116 & 286.8 \\
\hline
\end{tabular}

According to both the PCC and Spearman's rho, the data sets for economy size, trade value and trade diversity display statistically insignificant or very small correlations with average final bound tariffs and the number of specific commitments on service subsectors. In contrast, these same three independent variables display medium-sized to large correlations with the number commitment paragraphs in the report of the working party, which in turn, drive the generally large correlations with overall trade liberalization.

Essentially, economy size, trade value and trade diversity are all relatively good predictors of the number of commitment paragraphs in the report of the working party, but are not correlated in a meaningful way with other measures of trade liberalization. The findings are summarized in tables $5(\mathrm{e})$ and $(f)$.

Table 5(e) - Pearson Product Moment Correlation Coefficients for Trade Liberalization

\begin{tabular}{|c|c|c|c|c|c|}
\hline & & $\begin{array}{l}\text { Average Final } \\
\text { Bound Tariff }\end{array}$ & $\begin{array}{l}\text { Number of } \\
\text { Commitment } \\
\text { Paragraphs }\end{array}$ & $\begin{array}{l}\text { Number of } \\
\text { Specific } \\
\text { Commitments } \\
\text { on Service } \\
\text { Sub-sectors }\end{array}$ & $\begin{array}{l}\text { Overall Trade } \\
\text { Liberalization }\end{array}$ \\
\hline X & GDP & $0.090(-)$ & 0.966 & 0.084 & 0.767 \\
\hline & Trade Value & $0.105(-)$ & 0.974 & 0.153 & 0.804 \\
\hline (2) & $\begin{array}{l}\text { Trade } \\
\text { Diversity }\end{array}$ & $0.074(-)$ & 0.860 & 0.189 & 0.727 \\
\hline
\end{tabular}


Table 5(f) - Spearman Rank Correlation Coefficients for Trade Liberalization

\begin{tabular}{|c|c|c|c|c|c|}
\hline & 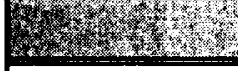 & Writury & 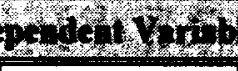 & ntry & 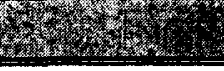 \\
\hline & & $\begin{array}{l}\text { Average Final } \\
\text { Bound Tariff }\end{array}$ & $\begin{array}{c}\text { Number of } \\
\text { Commitment } \\
\text { Paragraphs }\end{array}$ & $\begin{array}{l}\text { Number of } \\
\text { Specific } \\
\text { Commitments } \\
\text { on Service } \\
\text { Sub-sectors }\end{array}$ & $\begin{array}{l}\text { Overall Trade } \\
\text { Liberalization }\end{array}$ \\
\hline & Economy Size & 0.0710 & 0.499 & 0.044 & 0.508 \\
\hline$\cdots$ & Trade Value & $0.067(-)$ & 0.538 & 0.098 & 0.558 \\
\hline & $\begin{array}{l}\text { Trade } \\
\text { Diversity }\end{array}$ & $0.103(-)$ & 0.539 & 0.059 & 0.544 \\
\hline
\end{tabular}

In the author's view, there are two main conclusions that can reasonably be drawn from these findings. The first is that methodological challenges have likely had some influence on the results. More specifically, the significant variability in correlation coefficients among the three measures of trade liberalization relative to the three measures of negotiating scrutiny likely stems, at least in part, from the difficulty in measuring the former relative to the latter. The second conclusion is that the relationship between the independent variables and trade liberalization is more complex and consequently less direct, than the relationship between these variables and negotiating scrutiny. Interestingly, this conclusion lends some support to both the main hypothesis put forth in this paper and the competing hypothesis. To be more explicit, the fact that economy size, trade value and trade diversity are good predictors of the overall measures of negotiating scrutiny and at least one measure of trade liberalization supports the proposition that countries with large economies that trade a lot in a wide range of goods are subjected to more negotiating scrutiny from WTO members during the accession process and are required to undergo more trade liberalization. However, the fact that the independent variables are better predictors of negotiating scrutiny than trade 
liberalization supports the proposition that larger countries are able to leverage their market power to resist pressure from WTO members to liberalize their international trade regimes.

\subsection{Summary of Findings}

As mentioned in chapter three, in the author's view, the unique economic and political context of each accession and the built-in flexibility of the negotiations make it very difficult to draw definitive conclusions about the WTO accession process and its outcomes solely on the basis of broad-based empirical studies. Nevertheless, the research

findings presented in this chapter, particularly the consistently strong positive correlation between economy size, trade value and trade diversity and the various measures of negotiating scrutiny, point to some interesting general trends and themes that are explored in more detail in the case studies to follow. While the effect of economy size, trade value and trade diversity on trade liberalization in the accession context is undoubtedly more complex and difficult to measure, research findings can also be interpreted to suggest that a high degree of negotiating scrutiny often, but certainly not always, leads to more trade liberalization. 


\section{CASE STUDIES: PART 1-CENTRAL AND EASTERN EUROPEAN}

\section{COUNTRIES}

Following the break-up of the Soviet Union, many transition economies viewed WTO accession as an integral part of their economic reform efforts and their integration into the global economy. Accordingly, central and eastern European countries account for 12 of the 25 countries that have joined the WTO since its establishment in 1995. In addition, eight of the 18 non-LDCs currently in the process of acceding to the WTO are former members of the Soviet Union. For a number of transition economies accession took place more rapidly than on average. Some examples include Georgia, Armenia, Kyrgyzstan and the three Baltic states (Estonia, Latvia and Lithuania). The primary reason is that following the collapse of the Soviet Union these countries established the most liberal trade regimes among central and eastern European transition economies (Michalopoulos 20). For other countries such as Russia, Ukraine and Bulgaria, the accession process has been more difficult. For these countries, and many others, the lack of an institutional framework characteristic of market economies and necessary to implement WTO commitments, compounded by a lack of capacity to manage the negotiations effectively, as well as wavering political will, have made WTO accession challenging. These issues, and their interplay with the economic factors on which this paper focuses are explored in more detail below.

This chapter presents a detailed review and analysis of the WTO accession negotiations of Kyrgyzstan, Ukraine and Russia. Each case study involves a quantitative and qualitative review of the WTO accession process and its outcomes in terms of trade 
liberalization and other WTO commitments. Tables 6(a), (b) and (c) provide a summary of the quantitative data relating to each country's accession negotiations.

Table 6(a) - Economy Size, Trade, Value and Diversity in the Year of Accession

\begin{tabular}{l|r|r|r}
\hline \multicolumn{1}{c|}{ Country } & Kyrgyzstan & Ukraine & \multicolumn{1}{c|}{ Russia* } \\
\hline Year of WTO Accession & 1998 & \multicolumn{1}{c|}{2008} & $\begin{array}{c}2012 \\
\text { (projected) }\end{array}$ \\
\hline Economy Size (GDP in US\$ billions) & 1.6 & 180.4 & $1,477.00$ \\
\hline Total Trade Value in the Year of Accession (US\$ billions) & 1.1 & 152.5 & 560 \\
\hline Trade Diversity in the Year of Accession & 2 & 47 & 85 \\
\hline
\end{tabular}

*2010 data, which is the most recent available year

Table 6(b) - The WTO Accession Process

\begin{tabular}{l|r|r|r}
\hline \multicolumn{1}{c|}{ Country } & Kyrgyzstan & Ukraine & \multicolumn{1}{c}{ Russia } \\
\hline \hline Number of Working Party Members & 16 & 27 & 48 \\
\hline Number of Working Party Meetings (days) & 7 & 25 & 42 \\
\hline Page Length of the Report of the Working Party & 59 & 237 & 604 \\
\hline Overall Negotiating Scrutiny & 87 & 294 & 694 \\
\hline
\end{tabular}

Table 6(c) - Negotiating Outcomes

\begin{tabular}{l|r|r|r}
\hline \multicolumn{1}{c|}{ Country } & Kyrgyzstan & Ukraine & \multicolumn{1}{c}{ Russia } \\
\hline \hline Average Final Bound Tarif (ad valorem) & 7.5 & 5.8 & 7.8 \\
\hline Number of Specific Service Sub-sector Commitments & 118 & 137 & 116 \\
\hline Number of Commitments on WTO Rules & 29 & 63 & 163 \\
\hline Overall Trade Liberalization & 139.5 & 194.2 & 286.8 \\
\hline
\end{tabular}

\subsection{Summary of Quantitative Data}

With a GDP of only US $\$ 1.6$ billion in the year of accession, Kyrgyzstan has the third smallest economy among non-LDC countries to join the WTO. As can be seen in table 6(a) its economy is significantly smaller than those of both Ukraine and Russia.

Similarly, Kyrgyzstan's total trade value of US $\$ 1.1$ billion and its two HS chapters with 
trade values equal to or over US $\$ 100$ million rank third and second lowest respectively among non-LDC accessions. Ukraine's GDP of US $\$ 180.4$ billion in the year of accession gives it the fifth largest economy in the sample. Similarly, its trade value of US $\$ 152.5$ billion and trade diversity of 47 rank fifth and sixth largest respectively. ${ }^{6}$ Although Russia has not yet ratified its accession protocol, negotiations were formally concluded in November 2011 and its accession package was approved during the December 2011 WTO Ministerial Meeting. If Russia ratifies its accession protocol and becomes a WTO member in 2012, its GDP in the year of accession would be the largest of any acceding country since 1995 . Its total trade value of US $\$ 560$ billion would also be the largest among acceding countries, while its trade diversity of 85 would be second largest to China.

An analysis of the accession negotiations of Kyrgyzstan, Ukraine and Russia based on the figures in Tables 6(b) and (c) supports the main hypothesis of this paper and is generally consistent with the baseline data presented in the previous chapter. As evidenced by their respective negotiating scrutiny scores of 87,294 and 694 it is clear that Ukraine's accession generated considerably more interest and engagement from WTO members than Kyrgyzstan's and that Russia's accession, in turn, generated significantly more interest than Ukraine's. A degree of Russia's very high negotiating scrutiny score can perhaps be attributed to the excessive wordiness of certain sections of its working party report that reflect impenetrable Russian drafting as much as negotiating scrutiny. However, even if Russia's working party report were 200 pages shorter, it would still be almost twice as long as Ukraine's, which incidentally is also somewhat wordy. Thus, these findings are consistent with the prediction that countries that play a

\footnotetext{
${ }^{6}$ Refer to table 5(b).
} 
larger role in the global economy are subjected to greater negotiating scrutiny in the WTO accession process. With respect to negotiating outcomes, a similar but less pronounced trend can be observed. Although Russia's average final bound tariff is somewhat higher than Ukraine's and Kyrgyzstan's, by all other measures Russia underwent more trade liberalization than Ukraine, which in turn underwent more liberalization than Kyrgyzstan. Russia's overall trade liberalization score is 286.8 while the scores for Kyrgyzstan and Ukraine are 139.5 and 194.2 respectively. These findings are consistent with the prediction that countries with larger economies that trade more across a greater range of products are required to undergo more trade liberalization during the accession process.

\subsection{Kyrgyzstan}

Kyrgyzstan, which gained independence from the Soviet Union in December 1991, is a small, mountainous, landlocked country in Central Asia with a population of approximately 5.5 million. Kyrgyzstan is one of the poorest former Soviet Union countries with an estimated GDP per capita of US $\$ 2,200$. Agriculture is the dominant sector of the economy accounting for nearly 25 percent of GDP and employing nearly 50 percent of the labour force. The main agriculture commodities produced in Kyrgyzstan include cotton, wool, tobacco and meat. Only tobacco and cotton are exported in significant quantities. Kyrgyzstan is rich in mineral resources and has large deposits of coal, gold, uranium and other valuable metals. It is also a large producer and exporter of hydroelectric energy (CIA "Kyrgystan").

Kyrgyzstan requested accession to the WTO in February 1996, and based on its relatively progressive market reforms, joined the organization only 32 months later in 
December 1998. This made it the first Commonwealth of Independent States (CIS) member to accede to the WTO. ${ }^{7}$ The speed of Kyrgyzstan's accession can be largely attributed to the fact that by 1996 it had already undergone significant unilateral marketoriented reforms, including trade liberalization. As a result, negotiations proceeded rather smoothly and, to a large extent, took place within the scope of existing reforms. By most accounts, difficult concessions were not required (Globalization, WTO and the NIS).

Another factor that shaped Kyrgyzstan's accession process was the country's lack of capacity and expertise in international trade negotiations and the many technicalities of the WTO Agreements. This problem is not uncommon among acceding countries. As two observers have remarked:

...the necessary expertise to develop a negotiating strategy and then put it into effect during accession negotiations is simply not very abundant in those countries seeking WTO Membership. One might even say such expertise is simply non-existent outside a limited number of $O E C D$ countries (Mai and Lacey 5).

These limitations led the same observers to criticize Kyrgyzstan for its seeming lack of strategy in its accession negotiations and its consequent failure to seek to defend or advance any semblance of an industrial policy. Instead, they note, the emphasis was on joining the WTO as quickly as possible (4). While it is certainly true that in many respects Kyrgyzstan could have benefited from additional expertise in international trade negotiations, it strikes this author that some critics go too far in implying that it had no negotiating strategy. After the dissolution of the Soviet Union, free-market ideals were in the ascendancy in Eastern Europe in the 1990s. Rapid economic opening was in fact the development strategy of choice for many former members of the Soviet Union and WTO

\footnotetext{
${ }^{7}$ The CIS is a regional organization whose membership includes former Soviet Republics. It plays mainly a coordinating role in matters related to trade, finance, lawmaking and security.
} 
accession was often an important component of this strategy. This strategy was strongly supported by the United States (US) and other key WTO members who saw accession as a means to integrate former Soviet Republics into the western capitalist economic system. Thus, Kyrgyzstan and other former Soviet Republics were able to leverage the adoption of market reforms for capacity building and other forms of assistance from the US and other western powers. While the merits of this strategy and whether or not it was effectively implemented are legitimate points for debate, to suggest that Kyrgyzstan had no negotiating strategy is somewhat unfair to its political leadership at the time.

Kyrgyzstan's strategy of rapid trade liberalization is perhaps nowhere more apparent than in the agriculture industry, which as we have seen is critically important to its economy. On a global scale, agriculture is among the most politically sensitive and heavily protected and subsidized industries. Agriculture issues have often been the subject of contentious and difficult negotiations in the WTO. In consequence, WTO rules make a number of allowances for members to protect and support this industry. Thus, particularly given its low level of economic development, it is rather surprising that Kyrgyzstan made no use of such provision and agreed to relatively low bound tariffs for agriculture products. Kyrgyzstan's main WTO commitments pertaining to the agriculture industry are as follows: average final bound tariff of 12.7 percent, with only 0.3 percent of tariff lines bound at rates higher than 100 percent; no tariff rate quotas (TRQs); no special safeguard mechanism (SSG); and, a commitment not to provide trade-distorting domestic support to agricultural producers (WTO "Schedule CXLIl Kyrgyzstan"). This lies in stark contrast to many of the world's leading agricultural producers such as 
Canada, Brazil, the European Union (EU) and the US that make widespread use of high tariffs, TRQs, trade-distorting domestic support and other protectionist policies. ${ }^{8}$

Whether or not this outcome constitutes a problem for Kyrgyzstan, or is symptomatic of a lack of negotiating strategy, is open to interpretation. It is not difficult to imagine that some Kyrgyz farmers could feel that they would have benefited from more gradual exposure to international competition and more government support. Dani Rodrik and others would perhaps sympathize with such a position. However, drawing from the works of Frankel and Romer, Tang and Wei and others, we concluded in chapter two that trade liberalization should be considered an important contributing factor in a suite of market-oriented reforms that promote competition and economic growth. Thus, from this author's perspective, Kyrgyzstan's liberal agriculture trade policy regime, and its broader accession commitments, should be seen in a positive light.

Irrespective of one's views on the relationship between trade liberalization and economic growth, certain aspects of the negotiation process give cause for concern. In summarizing the main features of Kyrgyzstan's accession, one observer notes that "the preparatory process was not accompanied by informed discussions and debate..." and that "discussions took place among specialists, and this topic [WTO accession] was never widely discussed with the general public" (Globalization, WTO and the NIS). The same source attributes the lack of informed discourse to the fact that the Kyrgyz economy, having shrunk by more than 40 percent between 1991 and 1995, was in such disarray that it was impossible to widely discuss strategic interests and sectoral policies. Under these

\footnotetext{
${ }^{8}$ Details on tariffs, TRQs and SSGs can be found in WTO tariff profiles available at: http://stat.wto.org/TariffProfile/WSDBTariffPFHome.aspx?Language $=E$ Details on domestic support to agriculture producers can be found on the WTO Committee on Agriculture

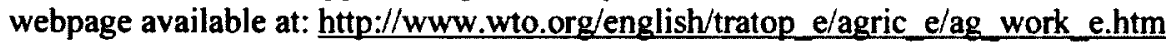


circumstances policy-makers were left with little choice but to focus on macro-economic stabilization.

Bearing these various considerations in mind, it appears that Kyrgyzstan's WTO commitments are as much a reflection of the prevailing economic thinking at the time, its lack of negotiating capacity and its difficult macro-economic situation in the years leading up to accession, as they are a result of informed policy choices toward economic liberalization. Ultimately, in the author's view, this outcome is more symptomatic of poor governance than problems with the WTO accession process. However, if the WTO wants to be seen as truly inclusive of all its members, current capacity building efforts by the Secretariat and core members to ensure that all members have the capacity to represent themselves effectively at the negotiating table should continue and, where possible, be enhanced.

Shortly after Kyrgyzstan joined the WTO in 1998 its economy went into a deep recession and debt crisis from which it did not recover until 2003. Although the recession was largely related to exogenous factors such as the Asian and Russian financial crises, WTO accession served as a convenient scapegoat for some opponents of reform in Kyrgyzstan and neighboring countries. Since accession commitments were made largely in the context of pre-existing reforms, it is difficult to imagine how becoming a WTO member could have had such a dramatic impact, positive or negative, on the Kyrgyz economy. If anything, WTO Membership prevented Kyrgyz policy-makers from backsliding on previous reforms and resorting to protectionist measures in the immediate post-1998 period (Pomfret 37). 


\subsection{Ukraine}

Next to Russia, the Ukrainian Republic had by far the largest economy in the Soviet Union. Its fertile land made it a large agriculture producer, yielding significant quantities of grain, meat, milk and vegetables. It also had a diversified heavy industry, supplying equipment and raw materials to industrial and mining sites throughout the Soviet Union. In the 1990s, reforms were met with much opposition resulting in a difficult and incomplete transition to a market economy. Although Ukraine's economy has gradually recovered and experienced modest growth over much of the last decade, its reliance on Russian energy supplies makes it particularly vulnerable to external shocks. With a population of roughly 45 million people, Ukraine's GDP per capita now stands at US $\$ 6,700$. Agriculture, industry and services account for 10 percent, 32 percent and 58 percent of GDP, respectively. Ukraine is an emerging world leader in the production and export of grain. It also produces and exports significant quantities of ferrous and nonferrous metals as well as machinery and transport equipment (CIA "Ukraine").

Ukraine applied for GATT/WTO Membership in 1993 and did not conclude the process until 15 years later in 2008 . The transition from a planned economy to a market economy was a major struggle for Ukraine. Following its independence from the Soviet Union in 1991, Ukraine's economy spent eight consecutive years in a deep recession. By 1999 , GDP per capita had fallen to only US $\$ 640$, almost a third less than the preindependence 1991 level of US $\$ 1,749$ (UN "Global Indicators Database"). This economic decline, combined with a lack of relevant expertise in government, limited meaningful progress on trade-policy reform and the accession process. To make matters worse, much of what little progress had been made was lost during a two-year hiatus 
between the sixth formal meeting of the working party in June 1998 and the seventh meeting in July 2000 (Granovsky, Burakovsky and Yurchyshyn 2). The hiatus stemmed from the Russian financial crisis of August 1998 that had serious spillover effects for neighboring countries. Ukraine, in effect, suffered its own financial crisis, including an 80 percent currency depreciation, sudden capital flight, skyrocketing interest rates and a sharp declines in wages and consumption. Not only was the crisis difficult from an economic perspective but, to an extent, it undermined political support for integration into the global economy. As we have seen, Kyrgyzstan was the first former Soviet Union country to join the WTO. And, the effects of WTO accession on the Kyrgyz economy were closely monitored and perhaps over-emphasized by other transition economies. When Kyrgyzstan suffered a recession in 1998, there was a cooling effect throughout the region in terms of enthusiasm for WTO accession (Pomfret 37). For these reasons, by most accounts Ukraine made little substantive progress toward WTO membership in the 1990s (Aslund 2009 224).

By the end of 1999 the negative trends in Ukraine's economy were reversed and in 2000 the country experienced modest economic growth for the first time in nearly a decade. ${ }^{9}$ When accession negotiations resumed in earnest in July 2000 , key government ministries, notably the Ministry of Economy and European Integration (MEEI), were benefiting significantly from considerable technical assistance from WTO members including the US, the EU and Canada. Among these capacity building efforts were two projects implemented by Carleton University's Centre for Trade Policy and Law (CTPL), including a Canadian International Development Agency (CIDA)-funded multi-year project (2000-2006) to assist Ukraine with its accession to the WTO and support more

\footnotetext{
${ }^{9}$ Source: United Nations Global Indicators Database. Available at: http://data.un.org/Explorer.aspx?d=IFS
} 
effective participation in the international trading system. ${ }^{10}$ Ukraine's accession effort also received a considerable political boost in the early $2000 \mathrm{~s}$ in the form of two Presidential Orders: “On additional measures aimed at speeding up Ukraine's accession to the World Trade Organization" of 5 September 2001; and, "On the program of measures to complete Ukraine's accession to the World Trade Organization" of 5 February 2002. The latter was particularly helpful in that it put forward a priority legislative action-plan for the alignment of Ukrainian laws with WTO rules. And, it sent a strong signal to the Ukrainian bureaucracy and to WTO members that Ukraine's political leadership was committed to concluding the accession process (Granovsky, Burakovsky and Yurchyshyn, 7). In many respects, these Presidential Decrees and others that followed set the stage for the slow but purposeful progress that characterized the remainder of Ukraine's accession negotiations.

Despite the renewed efforts commencing in 2000, Ukraine's accession bid still had to overcome some major challenges and took an additional eight years to complete. Ukraine was in the midst of a massive economic transformation, which was intrinsically tied to the accession process, and had a long way to go from the haphazard reform efforts of the 1990s. The task for Ukraine's reformers was twofold: first, market-based instruments had to replace direct state intervention as the primary means to execute economic policy; and second, a stable, predictable and transparent legal framework had to be developed to support the operation of the private sector (Lawrence 23). This task was made more difficult by the fact that the Ukrainian Parliament (the Rada) often did not consider WTO-related reforms a top priority (World Bank 2004 134). While Ukraine

\footnotetext{
${ }^{10}$ More details can be found at http://ctpl.ca/ctpl-projects/europe.
} 
was ultimately successful enough in its reform efforts to secure its place as a WTO member, the process was certainly not beyond reproach.

Similar to the experience of Kyrgyzstan, some observers criticized Ukraine's accession process for a lack of transparency and stakeholder consultations. Information sharing among relevant government ministries and between the government and key stakeholders, including parliamentarians and business leaders, was weak and in some cases non-existent. Although the MEEI made some public awareness efforts, the information flow operated only in one direction - from government to industry stakeholders. In other words, there was no institutionalized mechanism to incorporate information and feedback from the private sector into the process of developing trade policies and negotiating strategies (World Bank 2004 134-135). Once the negotiations were concluded, these shortcomings led to much trepidation that the accession protocol would not be ratified by the Rada. Parliamentarians had not been very involved in the process, did not have a firm understanding of how the WTO operates, and were thought to be inclined toward interpreting the various pre-conditions for accession as being imposed from outside. These concerns were exacerbated by the very polarized nature of Ukrainian politics and the tension between governing parties stemming from the Orange revolution of 2004 and 2005 (The Economist 2008). Despite these factors, on April 10, 2008, Ukraine's parliament voted to ratify the accession protocol by an overwhelming and record margin of 411 to 39 . As The Economist observed, this outcome reflected the fact that, at the time, both governing parties were: 
...backed by the country's leading industrialists, whose interests favour deeper integration with the global economy and in particular closer ties with EU markets, as well as Ukraine's continued evolution towards a business environment that protects property rights and regulates competition.

Thus, while it seems that the Ukrainian government's approach to the negotiations could have been more inclusive and better coordinated, it is clear that these factors were not so strong as to preclude the development of a strong and very politically influential coalition of interests in favour of WTO membership and deeper integration into the global economy.

Perhaps owing to this coalition of interests, Ukrainian negotiators were able to put forward offers on market-access for goods and services that were generally satisfactory to WTO members and to exhibit considerable flexibility on a number of key negotiating issues. With respect to goods, Ukraine's current average bound tariff of 5.8 percent is among the lowest of any country to join the WTO since 1995 . This average will drop marginally over the next year as some of Ukraine's scheduled tariff reductions will not be fully implemented until 2013. The main issue of contention in Ukraine's goods negotiations pertained to its import policies for sugar. Ukraine's 1999 "Law on the Regulation of Sugar Production and Sale" permitted imports of raw sugar only on the condition that resulting output (refined sugar) was subsequently exported. Ukraine also imposed a TRQ on sugar imports with a volume of 125,000 metric tones (MT). The inquota tariff was 30 Euro/MT while the over-quota tariff was 300 Euro/MT. Combined with the fact that licenses to import under the quota were auctioned off for 60 Euro/MT, the in-quota duty plus license cost amounted to a tariff of approximately 38 percent, while the over-quota duty was approximately 127 percent (World Bank 2004 123). 
Although some WTO members pushed for Ukraine to completely eliminate its TRQ on sugar imports, an acceptable compromise was eventually reached in the form of a gradual increase in quota volume to reach $267,800 \mathrm{MT}$ two years after accession. In addition to commitments on TRQ volumes, Ukraine's working party report contains a number of very specific provisions designed to ensure non-discrimination and transparency in how the quota is allocated (WTO "Working Party Report Ukraine" 32-34).

Another difficult area in the goods negotiation pertained to Ukraine's use of export restrictions (including export duties) to promote its domestic manufacturing industry. For instance, from 1996 to the date of accession Ukraine applied a duty of 17 percent on all exports of linseeds, sunflower seeds and flax seeds. This had the effect of reducing domestic seed prices and thereby promoting production of oils, margarines and fats. Similar export duties and other types of restrictions, including export licensing fees and requirements, were applied to livestock, livestock hides and scrap metal. A number of WTO members, notably the EU, complained that these measures were often prohibitive. Some members requested that Ukraine bind all export duties at zero upon accession (World Bank 2004 124). Again, a compromise solution was adopted. Ukraine committed to binding and reducing export duties upon accession. It was agreed that some duties would be gradually phased out, while others would simply be reduced. Transition periods range from five to 10 years following accession. Ukraine also committed to bringing export licensing fees and requirements in line with WTO rules (WTO "Working Party Report Ukraine" 57-63).

Beyond market-access negotiations, Ukraine was required to make a significant number of legal and institutional reforms to align its trade policies with WTO rules. 
Areas of particular focus included TBT and SPS measures, trade-related aspects of intellectual property rights (TRIPS) and agriculture subsidies. With respect to SPS measures and TBT, WTO members complained that Ukraine's import requirements, as well as certification and inspection procedures, were convoluted, overly restrictive, not science-based, and did not adequately take risk into account (World Bank 2004 126-129). To address these concerns, Ukraine consolidated and streamlined various laws and decrees governing SPS measures and committed in its working party report to implementing its TBT and SPS regimes in compliance with the relevant WTO agreements. A number of specific commitments were also made, including a commitment to give priority consideration to international standards, guidelines and recommendations as the basis for Ukraine's TBT measures, and a commitment to allow the import of meat from animals treated with hormones (WTO "Working Party Report Ukraine" 67-82).

One of the more high-profile issues addressed in Ukraine's accession negotiations related to the protection of intellectual property rights, and in particular, the production and export of counterfeit optical discs (CDs, CD-ROMS and DVDs). According to the International Intellectual Property Alliance (IIPA), a US-based advocacy organization, piracy in Ukraine cost its members up to US $\$ 250$ million annually throughout the early 2000s. This made Ukraine one of the world's largest violators of intellectual property rights and caused the US to revoke its duty-free treatment of goods imported from Ukraine under the Generalized System of Preferences (GSP). The US also imposed countervailing duties worth US $\$ 75$ million annually on imports from Ukraine (World Bank 2004 129). Reflecting the high profile nature of this dispute, the section of Ukraine's working party report dealing with TRIPS contains numerous paragraphs 
describing measures taken to reduce piracy of optical discs, including improvements in intellectual property laws, seizures of counterfeit goods by customs officials and criminal investigations and convictions. In addition to a commitment to apply the provisions of the TRIPS agreement upon accession, the report includes commitments on a number of specific enforcement measures designed to facilitate expeditious actions against enterprises, factories and persons suspected of producing and distributing pirated optical discs (WTO "Working Party Report Ukraine" 102-120).

A final point of interest in Ukraine's accession negotiations are agriculture subsidies. In WTO accession negotiations a country's ceiling commitment on tradedistorting domestic support, referred to as the final bound total aggregate measurement of support (AMS), is based on the average level of trade-distorting support applied in a three-year base period (referred to as base total AMS). WTO Secretariat guidelines on the accession process are not prescriptive about how the base period is established. As a result, this has become a particularly difficult area of negotiation. However, notwithstanding a few exceptional cases, a precedent has emerged whereby the most recent three-year period prior to accession for which data is available is used as an acceding country's base period for the purpose of determining the final bound total AMS commitment. ${ }^{11}$ When negotiations on domestic support began in the mid 1990s, Ukrainian negotiators proposed to use a base period from 1994 to 1996 , which at the time seemed reasonable. Using this base period would have yielded a base total AMS of over US $\$ 1$ billion. However, as the negotiations dragged on into the late 1990 s and then the 2000s, the 1994 to 1996 base period became less and less relevant in the eyes of WTO members as it no longer reflected the realities of Ukraine's agriculture sector or the level

\footnotetext{
"For a detailed discussion on domestic support in the context of WTO accessions, see Brink.
} 
of government support it received. This argument was well founded as Ukraine's levels of trade-distorting support declined significantly over the course of accession negotiations. For instance, use of a 1997-1999 base period would have resulted in a base total AMS of less that US $\$ 100$ million. In spite of this trend, Ukrainian negotiators continued to push for the 1994 to 1996 base period and argued for high levels of tradedistorting domestic support for transitional reasons, such as the need for one-time expenses to write-off old debts, rebuild infrastructure, complete land reforms and modernize the agriculture industry (World Bank 2004 130-131).

This issue was of particular concern for members of the Cairns Group because of Ukraine's potential as a producer and exporter of a wide range of agricultural products, and because of the precedent that would be set for Russia's, and to a lesser extent Kazakhstan's, accession negotiations. ${ }^{12}$ Although Russia and Kazakhstan have not yet acceded to the WTO, all three countries' accession negotiations have proceeded along similar timelines and all three countries pay close attention to one another's negotiations in order to inform their own strategies and gain any advantage possible. These factors helped to coalesce Cairns Group members into acting as an effective and wellcoordinated voice in the negotiations. Through their combined effort and negotiating weight, they eventually persuaded Ukraine to adopt a more recent base period from 2004 to 2006. Many observers also feel that the fiscal constraints facing the Ukrainian

\footnotetext{
${ }^{12}$ The Cairns Group is a unique coalition of 19 agricultural exporting countries with a commitment to reforming agricultural trade. A diverse coalition bringing together developed and developing countries from Latin America, Africa and the Asia-Pacific region, the Cairns Group has been an influential voice in the agricultural reform debate since its formation in 1986 and has continued to play a key role in pressing the WTO Membership to meet in full the far-reaching mandate set in Doha.

Despite significant domestic capacity constraints, Ukraine, Kazakhstan and Russia hold the potential to be agriculture giants. They are already global price setters for certain basic commodities such as wheat and have ambitious plans to increase production in a variety of sectors including grains, oilseeds, meat and dairy products.
} 
government, which in effect reduced its ability to disburse large sums to key industries, also contributed to this outcome. ${ }^{13}$ Whatever the decisive factor was, the 2004-2006 base period resulted in a considerably lower final bound total AMS commitment level of approximately US $\$ 373$ million (WTO “Schedule CLXII Ukraine”).

In summary, despite some shortcomings in the Ukrainian government's approach to stakeholder consultations, once Ukraine's economy recovered from the financial crisis of 1998, a strong and politically influential coalition of business interests emerged in favor of WTO accession and deeper integration into the global economy. This stakeholder support allowed Ukrainian negotiators to put forward very credible offers in terms of market-access for goods and services and to display considerable flexibility in other negotiations areas. Notwithstanding this flexible approach, Ukraine's WTO commitments and accounts of the negotiating process show evidence of a clear negotiating strategy oriented around protecting and supporting strategic sectors including sugar, oilseeds, meat and scrap metal processing among others. While Ukraine eventually backed down from some of its initial negotiating positions (i.e., trade-distorting domestic support), its negotiators successfully secured an extension of the sugar TRQ and significant transition periods for the reduction of export duties. In addition, although Ukraine's average tariff binding is low at 5.8 percent, it is worth underlining that in 2010 its average trade-weighted tariff on imports of agriculture products was significantly higher at 23.4 percent (WTO "Trade Profile Ukraine"). This shows further evidence of Ukraine's efforts to protect agriculture producers and lies in stark contrast to Kyrgyzstan,

\footnotetext{
${ }^{13}$ This account is based on multiple informal discussions the author had with negotiators from Canada and other Cairns Group members in Ottawa and Geneva from 2007 to 2011. These discussions took place primarily in the context of devising negotiating strategies to deal with Russia's request for a very high final bound total AMS commitment level, which has many parallels to the Ukrainian case.
} 
which has an average bound tariff of 7.5 percent and an average trade-weighted tariff on imports of agriculture products of only 7.7 percent.

\subsection{Russia}

With a GDP of US $\$ 1.5$ trillion in 2010 , Russia has the seventh largest economy in the world (counting the EU as a single economy) and, in economic terms, is by far the largest country outside of the WTO. With a total trade value of US $\$ 560$ billion in 2010 and 85 HS chapters with over US $\$ 100$ million, Russia also has a very large and diversified trade portfolio relative to other countries that have acceded to the WTO. Much like Ukraine, over the course of the 1990s Russia underwent a difficult transition from a centrally planned economy to a more market-based and globally-integrated economy. Through its economic transition, Russia has emerged as a leading commodity producer and exporter. In 2009, Russia was the world's largest natural gas exporter, the second largest oil exporter and the third largest exporter of steel and aluminum. Propelled by high commodity prices, the Russian economy grew at an average annual rate of seven percent from the end of the 1998 Russian financial crisis to the beginning of the 20082009 global economic crisis. This resulted in a doubling of disposable income and fostered the development of an emerging middle class (ClA "Russia").

Despite benefiting from a windfall of oil and gas revenues, Russian government efforts to promote economic diversification have produced few positive results. Russia's economy remains reliant on commodity exports and vulnerable to volatility in global commodity prices. This became apparent during the 2008-2009 global economic crisis when Russia's economy was one of the hardest hit. As oil prices plummeted and foreign credit dried up, the economy contracted by 7.9 percent. In response to the crisis, the 
Central Bank of Russia and the Russian government spent US $\$ 400$ billion to slow the devaluation of the ruble and increase liquidity in the banking sector. Despite rebounding with modest economic growth of 3.8 percent in 2010 , Russia's economy will continue to remain vulnerable until diversification efforts yield better results. Major challenges in this régard include a shrinking workforce, high levels of corruption, weak institutions, poor infrastructure and limited access to capital for small and medium-sized enterprises (CIA "Russia").

Russia applied to join the GATT/WTO in 1993 and concluded the negotiating process 18 years later in November 2011. Russia's accession package was formally adopted by the WTO Ministerial Council on December 16, 2011. The Russian parliament (the Duma) now has 220 days to ratify the agreement. Russia will formally become a WTO member 30 days after ratification. At a basic level, Russia's accession negotiations followed a similar path to those of Ukraine. The 1990s were a very difficult and unstable transition period for Russia. With the notable exceptions of energy and defense-related industries, most Russian industries were privatized by late 1994. However, as Russia lacked the political, economic and legal institutions necessary to support a wellfunctioning capitalist economy, the business environment remained very poor. Newly privatized firms failed to restructure or make the necessary investments in capital and research and development to remain competitive. ${ }^{14}$

In spite of lofty rhetoric, accession negotiations proceeded at a halting pace. There were ominous signs from the start. Upon handing over Russia's accession application to GATT Director General Arthur Dunkel, President Boris Yeltsin is reported

\footnotetext{
${ }^{14}$ For a detailed historical account of Russia's economic transition and an assessment of what went wrong see: Naray 23-82.
} 
to have said with a smile: "I hope that you will not put this on the back burner until the end of the decade. I hope that you will take a decision by the end of 1993" (Naray 21). This statement can reasonably be interpreted to reveal a serious underestimation of the complexity of the accession process and the legal reforms it required. This interpretation is supported by the fact that responsibility for accession negotiations was initially delegated to a deputy minister for international trade and garnered little political attention. As Anders Aslund, former economic adviser to the government of Russia, coyly remarks: "Implausibly, that Deputy Minister insisted every year that Russia would become a [WTO] member in a year or two. The disinterested senior politicians were inclined to believe him - or ignore him..." (Aslund 2010 51). This situation reflected the fact that much of the Russian political leadership viewed their country as a pure commodity exporter and failed to see the harm in their protectionist orientation. Another impediment to meaningful progress in the accession was that until December 1999, the Duma was controlled by communists and their allies, who were neither in favour of WTO accession, nor prepared to pass new legislation required for Russia to comply with WTO rules. A final challenge, similar to the cases of Ukraine and Kyrgyzstan, was that Russian officials lacked knowledge of the WTO and experience in international trade negotiations (51-52).

The 1998 financial crisis was a turning point for Russia's accession negotiations. The working party did not meet between December 1998 and May 2000. Over these 16 months President Yeltsin resigned and appointed Vladimir Putin as his successor. Putin subsequently won the presidential elections in March of 2000. In the economic sphere, many Russians took note of the great fanfare surrounding China's impending WTO accession (China joined in December 2001) and began to wonder if Russia's policies 
toward the organization had been misguided. At the same time, gradual structural changes in Russia's economy made WTO accession increasingly attractive to the business community. In particular, as production processes improved, exports of intermediary goods such as steel and fertilizer grew in importance to account for roughly a quarter of Russia's total exports. Exports of these products faced greater barriers, such as import quotas in the EU and US, than Russia's traditional oil and gas exports. These structural changes paved the way for the emergence of a new business elite that favored trade liberalization and WTO entry. As a result, upon taking office President Putin made WTO accession a top priority and heralded it as a tool for economic modernization (Aslund 2010 52-53).

From a practical perspective, a restructuring and renewal of the Russian bureaucracy helped to revitalize the accession process. The archaic and dysfunctional Ministry of External Economic Relations was abolished and its functions later merged with several other ministries to form the Ministry of Economic Development and Trade (MEDT). A large group of young and competent reformers emerged from within this newly formed ministry, including Minister German Gref and Deputy Minister and Chief WTO Negotiator Maxim Medvedkov. Another voice for reform, Finance Minister, Alexei Kudrin was given overarching responsibility for Russia's accession (Aslund 2010 53). By this time, much like their Ukrainian counterparts, Russian officials had benefited from significant technical assistance from the US, the EU and Canada. Again, CTPL played a significant role in this process with the implementation of five multi-year projects in Russia spanning 1995 to 2007, funded by CIDA and the United Kingdom's Department for International Development. These projects were designed to strengthen 
Russia's capacity in international trade policy issues and thereby support MEDT, and other government agencies, in furthering efforts to see Russia join the WTO and implement WTO-consistent policies. ${ }^{15}$

Unfortunately, Putin's second term as President (2004-2008), witnessed a shift in his focus from economic reform, to consolidating his power. This gave the siloviki ascendancy over reformers and created space for a protectionist lobby to gain strength. ${ }^{16}$ As is often the case, the agriculture industry, led by long-time Minister of Agriculture, Alexei Gordeev, was the most vocal in this regard (Aslund 2010 53). However, notwithstanding the loss of momentum during Putin's second term, the economic reform and restructuring that took place during his first term in office put WTO accession on the political map in Russia and set the country on a path, albeit a winding one, toward WTO membership.

Owing largely to wavering political will and the re-emergence of protectionist sentiment described in the preceding paragraphs, Russia's accession negotiations proved far more difficult than Ukraine's. The following paragraphs summarize Russia's key accession commitments and explore in more detail some of the most contentious issues that arose over the 18-year long negotiation. Topics covered include: tariff commitments; TRQs for meat imports; the ceiling commitment on trade-distorting domestic support to agriculture producers; services; TRIPS; SPS measures; and, TRIMS.

Concerning goods negotiations, Russia concluded bilateral agreements with most WTO members by the mid-2000s. The outcomes of these negotiations resulted in Russia

\footnotetext{
${ }^{15}$ More details can be found at http://ctpl.ca/ctpl-projects/europe. CTPL established a partner think tank in Moscow in 1997 and hired Maxim Medvedkov as the resident head of the office. By the time Medvedkov assumed his role as chief negotiator, he had gained a thorough appreciation of what would be involved.

${ }^{16}$ Siloviki is a Russian word for politicians or senior officials formerly from the security services. Vladimir Putin and many of his closest allies and advisors are often referred to as siloviki.
} 
committing to an average final bound tariff of 7.8 percent. For industrial goods, the average final bound tariff is slightly lower at 7.3 percent, while it is slightly higher for agricultural products at 10.8 percent. More than half of Russia's final bound tariff commitments will be implemented within three years of the date of accession. Other tariff reductions will be subject to phase-in periods as long as eight years (WTO "Press Release Russia"). With the exception of meat products, tariff negotiations were not especially difficult. Russia's use of TRQs to regulate meat (poultry, pork and beef) imports was in fact a major point of contention in the goods negotiations. Since the early 2000 s, the Russian government has invested heavily in the livestock and meat sectors and used restrictive TRQs to shield domestic producers from what it sees as too much international competition. However, much to the chagrin of the Russian Ministry of Agriculture and some of its most influential stakeholders, domestic supplies failed to keep up with growing demand and Russia became one of the largest global meat importers from the mid 2000s onward.

Historically, Russia's TRQs for meat were administered on the basis of countryspecific reserves, whereby pre-determined proportions of the TRQ volume were allocated to specific supplying countries. TRQ volumes and country allocations were initially negotiated in the early 2000 s when the market was much less lucrative and the US and EU were the dominant suppliers. As a result, the US and the EU were granted substantial country-specific allocations, with only modest TRQ volumes available to all other suppliers. By the mid 2000s, a number of new meat suppliers emerged in the Russian market from other countries including Brazil, Argentina and Canada. These countries argued for changes to Russia's meat TRQ regime, namely the elimination or 
redistribution of country-specific allocations to reflect their growing market-share. However, the US and EU resisted such changes and sought to preserve their historical position as dominant suppliers. Within Russia, meat processors favored liberalization of the meat import regime, which would provide them with cheaper and better quality inputs, while politically influential meat producers favored further import restrictions to support high domestic prices. Balancing these competing interests was exceptionally difficult for Russian negotiators and the TRQ negotiations became highly politically charged in Russia, the US, and to a lesser extent in Brazil, Canada, Argentina, Australia and Paraguay. A final agreement was not reached until August of 2011, when the Obama administration directly intervened, and undercut the United States Trade Representative's (USTR) negotiating position, in order to break a stalemate over the volume of Russia's pork TRQ. USTR had been seeking a volume of $480,000 \mathrm{MT}$ and was optimistic that Russia would acquiesce. However, ostensibly in response to political pressure from Russia, a senior official from the Obama administration intervened at the eleventh hour and indicated that the US could accept Russia's previous offer of 430,000 MT. This development produced a domino effect that saw other members agree to Russia's proposed post-accession meat TRQ regime, with only minor haggling. ${ }^{17}$

The end result of the negotiation was very much a mixed-bag from the perspective of major foreign suppliers. Although acceptable to all parties, the outcome was especially pleasing to none. Upon accession to the WTO, Russia will be allowed to maintain TRQs for pork and beef until 2020, at which time they will be replaced by MFN

\footnotetext{
${ }^{17}$ This account is based on the author's five years of experience (2007-2011) as the lead officer responsible for negotiations on Russia's meat TRQs within the government of Canada. This included representing Canada at a number of plurilateral meetings in Geneva and participating in numerous informal discussions with officials from Russia, the US, the EU, Brazil, Argentina, Australia, New Zealand, Paraguay, Uruguay, Chile and China.
} 
tariffs. The TRQ for poultry will remain in place indefinitely. Prior to being eliminated in 2020 , the pork TRQ will have a volume of $430,000 \mathrm{MT}$ from the date of accession onward. This represents a 70,000 MT reduction from the 2011 TRQ volume of 500,000 MT. In a victory for Brazil, Canada and others, country-specific allocations will be eliminated and the TRQ will be allocated on an MFN basis. As for poultry, the volume of the poultry TRQ will be set at $344,000 \mathrm{MT}$ upon accession. This represents a modest reduction of $6,000 \mathrm{MT}$ from the $2011 \mathrm{TRQ}$ volume of $350,000 \mathrm{MT}$, but a reduction of more than half of the 2010 volume of $780,000 \mathrm{MT}$. In addition, the scope of product coverage will be significantly reduced and tailored largely to US and EU export interests. Finally, the frozen beef TRQ will remain at its 2011 volume of 530,000 MT until its elimination in 2020. Country-specific allocations will remain split between the EU, the US, and the "other countries" allocation, to which all other suppliers have access. In keeping with changes that Brazil, Canada, Argentina and other suppliers successfully lobbied for in 2009, 77 percent of the beef quota volumes will be assigned to the "other countries" allocation (WTO "Schedule CLXV Russia").

This tightening of Russia's TRQs for pork and poultry is without precedent in the accession context, which normally requires countries to increase TRQ volumes and phase out TRQs over a specified timeframe. This outcome speaks to the strong protectionist sentiment in Russia's meat sector and the Ministry of Agriculture, and the perhaps grudgingly pragmatic approach of WTO members. Ultimately, members came to accept that the only way they could hope to bear any influence on Russia's meat import regime is through WTO commitments, and that Russia could not agree to commitments that would be perceived as overly damaging to the interest of domestic producers. This was a 
particularly bitter pill to swallow for the US as Russia had long been its largest export market for poultry with annual exports averaging $\$ 692$ million in value from 2005 to 2009 (Global Trade Atlas).

A second difficult negotiating issue also pertaining to the agriculture industry is Russia's final bound total AMS commitment level. Russia was much bolder than Ukraine in this area of the negotiations and flatly argued a need for a high commitment level on trade-distorting support that far exceed applied support during recent base periods. This so-called "need" was derived from the Russian government's goal of modernizing and revitalizing its agriculture sector after a disastrous period of decline for more than a decade following the collapse of the Soviet Union. Russian negotiators emphasized the high level of poverty in rural areas and stressed that government assistance was necessary to support the livelihoods of Russia's many rural farmers. The Russian government's strategies and programs for supporting the agriculture industry are articulated in a series of five-year plans, the most recent of which is the "Government Program for the Development of Agriculture and Regulation of Markets of Agricultural Products, Raw Materials and Food for years 2008-2012". Under this program and its predecessors, Russia dramatically increased trade-distorting support to agricultural producers from negligible levels in the early 2000 s to a projected peak of US $\$ 9$ billion in $2012 .{ }^{18}$ In order to accommodate this program, which the Russian Ministry of Agriculture and its senior political leadership committed to publicly, Russian negotiators requested a final bound total AMS commitment of US\$ 9 billion.

\footnotetext{
${ }^{18}$ USDA Gain Report number RS7051 provides a detailed summary of the program. This and other GAIN reports can be found via a searchable database on the USDA website available at: http://gain.fas.usda.gov/Pages/Default.aspx.
} 
Owing largely to Russia's potential to be a global leader in the production and export of agriculture products, namely cereals and oilseeds, Cairns Group members strongly opposed the proposed US $\$ 9$ billion final bound AMS commitment. This opposition stemmed from long-term competitive concerns, specifically not wanting their producers to have to compete with heavily subsidized Russian products in third markets. Among this group, Canada, Brazil and Australia were the key players. These countries mobilized the Cairns Group as a whole and defended the accession precedent of the final bound total AMS being derived from average applied levels of trade-distorting support during a recent three-year base period. As negotiations on this issue approached their conclusion in the summer of 2011, the applicable base period for Russia was 2006-2008, during which the average annual level of trade distorting support was US $\$ 4.4$ billion.

Despite initially being very far apart, the parties eventually agreed on a compromise solution that allowed for Russia's AMS commitment level to peak at US $\$ 9$ billion in 2012 and 2013 , only to be reduced thereafter to reach a final bound commitment level of US 4.4 billion in 2018 (WTO "Schedule CLXV Russia"). This solution allows all parties to meet their central negotiating objectives. It enables the leadership of the Russian Ministry of Agriculture to live up to its commitment to provide high levels of trade distorting support over the short-term. At the same time, members of the Cairns Group can also legitimately claim to have succeeded in limiting Russia's ability to continue to provide high levels of trade distorting support over the long-term and thereby mitigating the possibility of future competitive challenges posed by subsidized Russian products. ${ }^{19}$

\footnotetext{
${ }^{19}$ This account is based on the author's five years of experience (2007-2011) as one of a small group of officials responsible for negotiations on Russia's final bound total AMS commitment level within the
} 
Services were another important aspect of the negotiations. Russia's accession protocol includes commitments on 11 service sectors, most notably telecommunications, insurance, banking, transportation services and distribution services (WTO "Press Release Russia"). Of these various commitments, those in the banking and insurance sectors were the most politically contentious and difficult to agree upon. With respect to banking, Russia agreed to bind most existing market-access and offered some liberalization in the treatment of foreign banks and subsidiaries, including but not limited to: allowing 100 percent foreign ownership of all commercially meaningful types of noninsurance Russian financial companies (i.e., banks, broker dealers, investment companies); allowing foreign-invested companies to own and trade the full range of securities and participate in financing of privatization of government-owned firms; and, allowing cross-border services such as financial leasing, financial information and data processing, credit cards and asset management services (USTR 2006 "Services").

An important area of the services negotiations in which Russia was unwilling to yield to pressure from WTO members was on the issue of branch banking. Subsidiaries of international banks are allowed to operate in Russia. However, they must be registered as Russian entities and are thus subject to the supervision of the Russian central bank and are required to have their own capital. In contrast, branch banks do not have legal status and are therefore not subject to such requirements. Consequently, entry into banking services is generally easier in countries where branch banks are permitted. This was a key negotiating objective for the US, which had been trying to ensure that all non-LDC countries acceding to the WTO allowed branch banking. The Russian central bank argued Group meetings in Geneva as well as participating in numerous informal discussions with officials from Russia, the US, the EU, Brazil, Argentina, Australia and New Zealand among others. 
that the lack of supervision and regulation of branch banks would pose a risk to depositors. Meanwhile, banking interests in Russia organized around this issue and succeeded in getting then President Putin to signal that it was a deal breaker (Tarr 7-8). In the end, this pressure tactic succeeded, as Russia's bilateral agreement with the US is open-ended on the issue of branch banking and states only that Russia will reconsider its approach upon joining the Organization for Economic Cooperation and Development (OECD) or during the Doha Round negotiations, whichever comes first (USTR 2006 “Services").

With respect to insurance, Russia agreed to a number of significant marketaccess concessions despite reportedly serious concerns from domestic insurance providers, who feared excessive competition from larger and more efficient multinationals (Tarr 5-6). Key concessions include: allowing 100 percent foreign ownership of non-life insurance firms; eliminating limits on the number of life insurance permits granted to foreign-invested insurance firms; and, allowing foreign insurance companies to open direct branches for life and non-life insurance nine years after accession (USTR 2006 "Services").

The protection of intellectual property rights (IPRs) also received considerable attention over the course of Russia's accession negotiations. The US and other WTO members had serious concerns related primarily to optical disc piracy and internet piracy. In its 2006 bilateral market-access agreement with the US, Russia agreed to a binding action-plan to address piracy and counterfeiting and improve the protection and enforcement of IPRs (USTR 2006 "IPR"). In addition, Russia's accession protocol includes commitments to: fully apply the provisions of the TRIPS agreement upon 
accession; continue to take enforcement measures against websites and companies that infringe on copyrights and related rights; and, apply all rules of the Berne Convention for the Protection of Literary and Artistic Works (WTO "Press Release Russia").

With respect to SPS measures, Russia has undertaken considerable efforts to streamline, consolidate and clarify relevant legislation, as well as bring the application of its SPS regimes into compliance with WTO rules. Throughout working party deliberations on SPS issues, members repeatedly chastised Russia for the lack of transparency and predictability in the application of its SPS regime. These complaints were stoked by frequent market closures and restrictions resulting from a wide range of import requirements and procedures that WTO members considered to be overly restrictive and not based on science. The chapter of the working party report that deals with SPS issues was the second to last to be completed and is exceedingly long at 66 pages. It contains lengthy sections with detailed commitments on issues such as: veterinary import requirements, including veterinary export certificates and the approval of foreign establishments; harmonization with international standards; and, transparency and notification among many more (WTO "Working Party Report Russia" 207-273). The US and the EU worked closely with Russia on the final drafting of this chapter for several months during the spring and summer of 2011. Russia's key commitments on SPS issues include the following: to develop and apply all SPS measures in conformity with the WTO agreement and relevant international standards; to suspend, cancel or refuse import permits only for reasons consistent with the WTO agreement and relevant international standards; to renegotiate veterinary export certificates that are inconsistent with international standards with interested WTO members prior to January 1, 2013; and, not 
to suspend imports from foreign establishments for failure to meet Russian requirements without first giving them the opportunity to implement corrective measures (WTO "Press Release Russia").

The last substantive trade policy issue to be resolved in the negotiations pertained to Russia's use of TRIMS to stimulate the domestic automobile manufacturing industry. WTO members, in particular the EU, objected to Russia's distortionary automobile investment program. The program includes local content requirements that firms must meet in order to qualify for reduced tariff rates on imported parts, and is widely perceived to be inconsistent with the TRIMS Agreement. The law in question, enacted in December 2010 , also includes a trade balancing-provision, requires automobile engines to be fully manufactured in Russia, and requires foreign-invested vehicle manufacturers to register a certain number of patents in Russia and produce between 300,000 and 350,000 automobiles annually (Inside U.S. Trade). The relevant section of the working party report was not concluded until late October 2011 , only a few short weeks before the working party formally approved Russia's accession package. In the end, Russia agreed to eliminate WTO-inconsistent measures within its automobile investment program, but not until July 1, 2018. For all other sectors, Russia committed to complying with the TRIMS Agreement upon accession to the WTO (WTO "Working Party Report Russia" $280-281)$

As previously noted, Russia's WTO accession garnered considerably more interest from WTO members than did those of Kyrgyzstan and Ukraine. Consequently, its trade policies and practices have been subjected to considerably more scrutiny during the negotiating process. The main point of distinction between Russia's accession 
negotiations and those of Kyrgyzstan and, to a lesser extent Ukraine, is Russia's ability to clearly define and defend strategic interests. The most obvious examples are the agriculture and automobile industries. In both cases, Russia secured significant accommodations and departures from WTO precedents with respect to the establishment of its final bound total AMS commitment level, its meat-import regime and its automobile investment program. Russian negotiators also scored a significant 'victory' on the issue of branch banking, despite a strong push from the US and others. Such negotiating outcomes run counter to the second part of the main hypothesis put forth in this paper, which predicts that countries subjected to more negotiating scrutiny undergo more trade liberalization. According to the quantitative measures used in this paper Russia underwent more trade liberalization than either Kyrgyzstan or Ukraine. However, the significant flexibility it secured from WTO members on key negotiating issues demonstrates how larger countries are able to use their market size and other sources of bargaining power to their advantage and thereby counteract pressure from WTO members to liberalize sensitive industries. 


\section{CASE STUDIES: PART 2 - ASIAN COUNTRIES}

After central and eastern European countries, Asian countries represent the next largest geographical grouping of countries to have acceded to the WTO - six of the 25 countries that have joined the WTO are located in Asia. Of these six, the accession negotiations of China, Chinese Taipei and Vietnam were the most high-profile and economically weighty, while the accession of Mongolia, Cambodia and Bhutan received less fanfare. As was the case for central and eastern European countries, WTO accession was part of a broader transition from communist to capitalist economic systems for some Asian countries, namely China, Vietnam, Mongolia and Cambodia. However, in countries such as China and Vietnam, economic reform, including trade liberalization, was initiated a decade earlier than in Eastern and Central Europe and consequently occurred in a much more gradual and measured fashion.

The following paragraphs offer an in-depth review of the accession negotiations of Mongolia, Vietnam and China. Tables 7(a), (b) and (c) provide a summary of the quantitative data pertaining to each country's accession. Information in these tables not referenced in previous chapters can be found in the working party reports on the WTO accessions of the three countries under review and other official documentation publicly available through the WTO website accessions gateway.

\subsection{Summary of Quantitative Data}

Mongolia is the smallest non-LDC economy to join the WTO with a GDP of only US $\$ 1.1$ billion in the year of accession. With a total trade value of US $\$ 0.9$ and only one HS chapter with trade value equal to or over US $\$ 100$ million, Mongolia also has the smallest and least diversified trade profile of any non-LDC to accede to the WTO. 
Table 7(a) - Economy Size, Trade, Value and Diversity in the Year of Accession

\begin{tabular}{l|r|r|r}
\hline \multicolumn{1}{c|}{ Country } & Mongolia & \multicolumn{1}{c|}{ Vietnam } & \multicolumn{1}{c}{ China } \\
\hline Year of WTO Accession & 1997 & 2007 & \multicolumn{1}{c}{2001} \\
\hline Economy Size (GDP in US\$ billions) & 1.1 & 68.6 & $1,324.8$ \\
\hline Total Trade Value in the Year of Accession (US\$ billions) & 0.9 & 111.3 & 509.8 \\
\hline Trade Diversity in the Year of Accession & 1 & 72 & 92 \\
\hline
\end{tabular}

Table 7(b) - The WTO Accession Process

\begin{tabular}{l|r|r|r}
\hline \multicolumn{1}{c|}{ Country } & Mongolia & Vietnam & \multicolumn{1}{c}{ China } \\
\hline \hline Number of Working Party Members & 17 & 36 & 54 \\
\hline Number of Working Party Meetings (days) & 9 & 15 & 41 \\
\hline Page Length of the Report of the Working Party & 26 & 198 & 174 \\
\hline Overall Negotiating Scrutiny & 52 & 250 & 269 \\
\hline
\end{tabular}

Table 7(c) - Negotiating Outcomes

\begin{tabular}{l|r|r|r}
\hline \multicolumn{1}{c|}{ Country } & Mongolia & Vietnam & \multicolumn{1}{c}{ China } \\
\hline Average Final Bound Tariff (ad valorem) & 17.5 & 13.4 & 10 \\
\hline Number of Specific Service Sub-sector Commitments & 20 & 105 & 93 \\
\hline Number of Commitments on WTO Rules & 17 & 70 & 146 \\
\hline Overall Trade Liberalization & 19.5 & 161.6 & 229 \\
\hline
\end{tabular}

With a GDP of US $\$ 68.6$ billion in the year of accession, Vietnam has the sixth largest

economy in the sample. Vietnam's total trade value in the year of accession of US \$111.3 billion and its $72 \mathrm{HS}$ products categories with over US $\$ 100$ million in total trade value rank sixth and fourth highest respectively among completed accession negotiations.

Relative to the size of its economy, Vietnam has the largest and most diversified trade profile of any acceding country, reflecting its high degree of integration into the global economy. Finally, with a GDP of US $\$ 1.3$ trillion in the year of accession, China is the second largest economy to conclude WTO accession negotiations. Its total trade value in 
the year of accession of US $\$ 509.8$ billion, and its 92 HS product categories with over US $\$ 100$ million in total trade value rank second and first respectively in the sample.

As with the central and eastern European case studies, quantitative research findings are consistent with the central hypothesis of this paper. Commensurate with its economic size and larger and more diverse trade profile, China was subjected to the most negotiating scrutiny and underwent the highest degree of trade liberalization, followed by Vietnam then Mongolia. To be exact, Mongolia's, Vietnam's and China's scores for overall negotiating scrutiny are 52,250 and 269 respectively, while the scores for overall trade liberalization are 19.5, 161.6 and 229. An interesting aspect of these findings is that despite being a significantly larger player in the global economy, China's negotiating scrutiny score is only marginally higher than Vietnam's. A closer look at the underlying data reveals that this outcome can be largely attributed to the uncharacteristically focused and succinct drafting of China's working party report. For example, China's working party report is 174 pages in length and contains 146 commitments on WTO rules, whereas Vietnam's working party report is slightly longer at 198 pages, but contains only 70 commitments on WTO rules. In a more extreme example, Russia's working party report is 604 pages in length and contains 116 commitments on WTO rules. Thus, in China's case, the negotiating scrutiny score likely somewhat underestimates the degree of negotiating scrutiny to which it was subjected relative of other acceding countries.

\subsection{Mongolia}

Mongolia is a large and mountainous, landlocked country in Central Asia. Its sparse population of an estimated 3.1 million inhabitants remains relatively poor, with a GDP per capita of US $\$ 3,600$. However, the country has experienced strong economic 
growth for the better part of the last 10 years and seems poised to continue this positive trend, with 6.1 percent GDP growth in 2010. Although Mongolia's economy has historically been based on agriculture and herding, much of the recent economic growth can be attributed to the development of the mining sector. Mongolia has significant deposits of copper, gold, coal, molybdenum, fluorspar, uranium, tin, and tungsten that attract much foreign investment and generate a significant proportion of government revenues. Notably, in 2009 , the government approved an investment agreement to develop the Oyu Tolgoi mine, which holds among the world's largest copper deposits (CIA “Mongolia").

At its height, Soviet assistance accounted for one third of Mongolia's GDP. The dissolution of the Soviet Union in 1990 and 1991 brought an abrupt end to this aid, causing a serious economic crisis and setting Mongolia on a course of economic reform, based on free-market economics and extensive privatization (CIA "Mongolia").

Mongolia applied to join the GATT/WTO in October 1991 and concluded the process six years later in January 1997. Despite seemingly being granted less rigorous terms of accession than other countries, much like Kyrgyzstan, many observers see Mongolia's WTO commitments as unfavorable. This view is based largely on the perception that Mongolia was ill prepared for the negotiations, having not conducted any serious analysis of the consequences of becoming a WTO member, and consequently failing to develop a coherent negotiating strategy. This theme is explored in more detail in the following paragraphs.

Seeking WTO membership was reportedly among Mongolia's first independent foreign policy decisions. Mongolia's main objectives in the negotiations were political in 
nature; it wanted to become a WTO member before its two large neighbors, China and Russia, and it wanted to demonstrate to the world that it was committed to marketoriented reforms (Tsogtbaatar "Expectations and Realities"). Beyond the identification of these basic objectives, it is reported that little analysis was conducted. As explained by Damdin Tsogtbaatar, former foreign policy advisor to the President of Mongolia: "Mongolia's accession took place in a burst of euphoria without serious economic calculations or a solid cost-benefit analysis" (Tsogtbaatar "Mongolia" 250). As with many developing countries, much of this dearth of analysis can be attributed to an overall lack of government capacity. For example, H. Oyuntsetseg, former Counselor at the Mongolian Embassy in Brussels, reports that at the outset of Mongolia's accession negotiations there were no experts in market economics in the public service and the legacy of central planning remained strong. Even at the height of the negotiations, Mongolia had only three or four lead officials working on the file in the Ministry of Trade and Industry and one subject matter expert posted to the Mission in Geneva (1213).

Another feature of Mongolia's accession that contributed to the analytical deficiencies in its approach was the lack of consultation and information flow among government, the business community and civil society. When the negotiations began in 1991, there were virtually no private enterprises in Mongolia. As a result, the accession process was driven entirely by the government's political objectives. Even six years later as the negotiations reached their conclusion and the private sector had grown to account for nearly 60 percent of GDP, the government maintained its monopoly over WTO matters. For this reason, many private firms in Mongolia still neither fully comprehend 
the potential opportunities that come from WTO membership, nor are they well organized to capitalize on them (Tsogtbaatar "Expectations and Realities"). Instead, the private sector views the WTO as a foreign institution that provides “...fashionable talking fora for the government bureaucrats with little relevance to earthly needs of Mongolian industries" (Tsogtbaatar "Expectations and Realities"). These factors have led some observers to conclude that Mongolia's terms of accession were unfavorable, as they included far-reaching trade liberalizing commitments, without sufficient transitions periods and other flexibilities that many would think appropriate for a developing country facing serious economic challenges (Tsogtbaatar "Mongolia" 250).

Despite these perceptions, Mongolia's WTO commitments are not especially onerous. The gap between Mongolia's average bound tariff (17.5 percent) and its applied tariffs ( 5 percent for the vast majority of products) allows the government some policy space to raise tariffs and shield domestic producers from possible injury (Ministry of Foreign Affairs and Trade of Mongolia 1). Regarding services, Mongolia's schedule of commitments includes extensive liberalization, with minimal restrictions on marketaccess or national treatment in the following sectors: business services (including various services incidental to mining); communications services; construction and related engineering services; distribution services; financial services (including insurance and banking); and, tourism and travel-related services (WTO "Schedule CXXXIV Mongolia"). However, as shown in Table 6(b), Mongolia's commitments cover far fewer sub-sectors than those of other acceding countries. Moreover, Mongolia's extensive domestic privatization process and other liberalizing reforms went far beyond its WTO commitments on services (Ministry of Foreign Affairs and Trade of Mongolia 2). In 
terms of commitments on WTO rules, the implementation process was somewhat arduous due to Mongolia's lack of technical expertise on the WTO and its agreements. However, donors such as the German Technical Cooperation Agency, USAID and the United Nations Development Program played an important role in supporting the Mongolian government in the implementation of its WTO commitments and in building public awareness of the possible benefits of WTO membership (2-3).

The most significant and often cited example of where Mongolia's WTO commitments posed some difficulties for domestic industry is in the cashmere sector. Mongolia is the second largest global producer of cashmere after China. Cashmere is also Mongolia's fourth largest export product behind copper, gold and zinc (Global Trade Atlas). The cashmere sector is one of a limited number of truly globally integrated industries in Mongolia, is of much strategic value and plays an important role in setting the tone for the industrial sector as a whole (Tsogtbaatar "Mongolia" 260). In an effort to promote the development of the domestic cashmere processing industry, Mongolia introduced a ban on raw cashmere exports in 1994. The ban remained in place until 1996 when, as part of its WTO commitments, Mongolia agreed to convert it to a 30 percent export duty to be phased out within 10 years following the date of accession (Drabek and Bacchetta 1110). However, due to two major implementation problems, the export duty did not fully serve its purpose of restricting exports. First, rather than adopt an ad valorem duty, Mongolian authorities decided to impose an equivalent specific rate duty of 4,000 tugruks per MT. In implementing this duty, Mongolian authorities failed to account for fluctuations in global cashmere prices, which rose precipitously in the years following accession. Consequently, the rate of 4,000 tugruks per MT was often 
equivalent to less than 10 percent of the value of raw cashmere (Tsogtbaatar "Mongolia" 261). Second, Mongolian authorities did not have the capacity to effectively regulate the flow of goods across its borders. For example, in 1996 it was estimated that Mongolia exported 1,000 MT of cashmere to China, with all but $16 \mathrm{MT}$ being smuggled and thus escaping the export duty. While domestic processors complained of high input prices and shortages of raw cashmere, herders, whose income had declined by 50 per cent as a result of the export ban, greatly benefited from the opportunity to seek higher returns in the Chinese market (Drabek and Bacchetta 1110). Implementation problems aside, because of strong political pressure from domestic processors the Mongolian government successfully negotiated a five-year extension of the export duty on raw cashmere from a 10-year phase out to a 15-year phase out following the date of accession (Ministry of Foreign Affairs and Trade of Mongolia 2-3). Thus, while it is clear that Mongolia's WTO commitments on cashmere led to some difficulties for domestic processors, these difficulties were greatly exacerbated by the Mongolian authorities' inability to effectively implement and enforce export duties. Moreover, WTO members proved sympathetic to the political sensitivity of this issue and granted Mongolia flexibility that went beyond its accession commitments in phasing out the export duty.

For the reasons explained in the preceding paragraphs, even some critical observers have concluded that on balance, Mongolia's WTO membership "has not been too painful" (Tsogtbaatar "Mongolia" 260). The same observer aptly notes that the economic challenges Mongolia faced throughout the 1990s stemmed primarily from factors unrelated to the WTO accession process. In the early 1990s, Mongolia's economic challenges were related to the transition from a centrally-planned economy (that relied 
heavily on Soviet assistance) to a market-economy, of which WTO accession was only one part. Indeed, Mongolia`s economy had been struggling long before its WTO commitments came into effect. Likewise, in the late 1990s, Mongolia's economic struggles, notably its large trade deficit, can be largely attributed to the 1997 Asian financial crisis (260).

To conclude, Mongolia's accession bears many similarities to that of Kyrgyzstan in that both countries pursued WTO membership largely for political objectives at a time of significant economic turmoil and, in many respects, lacked the capacity to develop and implement effective negotiating strategies. In both cases, this led to some understandable criticism about the negotiating process lacking transparency and a solid analytical basis. Notwithstanding these shortcomings, Mongolia's initial objective of demonstrating its commitment to trade liberalization to the world has proven to be a viable and successful strategy. In particular, Mongolia's commitments to liberalize trade in engineering and constructions services, as well as other measures to improve the investment climate, have proven very fruitful. Since becoming a WTO member, Mongolia's mining sector has attracted significant foreign direct investment from global mining leaders including Canada-based Ivanhoe Mines Ltd., and the mining sector has become an engine of growth for the economy as a whole. Overall, the value of foreign direct investment in Mongolia during the seven-year period immediately following WTO accession (19972003) grew almost six-fold relative to the seven-year period prior to accession (19901996) (WTO "Trade Policy Review - Report by Mongolia" 11). Thus, while it is difficult to distinguish the effects of WTO accession from the much broader economic reform processes that Mongolia underwent during the 1990s, Mongolia's economy has 
experienced very strong growth over the last decade. Again, while one must be careful not to ascribe too much credit to WTO membership (or too much blame as the case may be), it is clear that in Mongolia s case the accession process was an integral part of a difficult, but to date successful, transition from a centrally-planned economy to an increasingly globally integrated market economy.

\subsection{Vietnam}

Vietnam is a densely populated developing country in Southeast Asia, with a long coastal border. Its population is estimated at 90.5 million. With a GDP per capita of US $\$ 3,100$ Vietnam is the poorest of the three Asian economies being examined in this chapter. Vietnam has been a communist state since North Vietnamese forces overran the South and reunited the country in 1975 . The first decade of communist rule was marked largely by economic isolation and stagnation. However, the last 25 years have witnessed significant economic liberalization and remarkable growth. Vietnam's key export products include crude oil, woven and knit apparel, fiber optic cables, footwear and fish (CIA "Vietnam").

Vietnam's economic reform and integration into the global economy began in 1986 with the launch of 'Doi Moi' (Renovation) and the adoption of an export-led growth strategy. This process has seen agricultural production play a diminishing role in the economy and the emergence of an increasing number of internationally competitive export-oriented industries. Over the 20-year period from 1986 to 2006, Vietnam's GDP growth averaged 7.3 percent per year, while exports grew at an annual rate of nearly 17 percent, resulting in considerable poverty reduction (Boumellassa and Valin 14). Vietnam's economic reform process received an important symbolic and substantive 
endorsement with its accession to the WTO in 2007. By 2008, its impressive economic performance led The Economist to dub Vietnam "The Other Asian Miracle" along with China (Economist "Vietnam"). Despite its commitment to economic reform, Vietnam's SOEs, whose production accounts for 40 percent of GDP, still play a major role in the economy. For this reason, Vietnam is now commonly referred to as a socialist-oriented market economy (CIA "Vietnam").

Vietnam applied to join the WTO in 1995 and concluded the process 11 years later in 2006. Although the accession process was formally initiated in 1995, negotiating efforts did not gain serious momentum until the latter half of 2003. From this point multilateral negotiations, bilateral negotiations and domestic consensus building around continued trade liberalization all progressed relatively quickly (World Bank 2006 14). Vietnam was already a decade into 'Doi Moi' when it applied to join the WTO and by 2003 had undertaken considerable trade liberalization through both regional and bilateral trade agreements. It joined the Association of Southeast Asian Nations (ASEAN) in 1997, concluded a bilateral trade agreement with the US (USBTA) in 2000, and signed the ASEAN free trade agreement (AFTA) in 2001. Hence, Vietnam's WTO accession was neither the focal point of its economic reform process, nor was it symbolic of a new era. Rather, WTO membership was a calculated and deliberate culmination of a 20-year transition from economic isolationism to a highly globally integrated socialist-oriented market economy. Herein lies an important feature of Vietnam's approach to accession that distinguishes it from Mongolia, Kyrgyzstan and other countries that were not as well prepared for the process: Vietnam had clear and specific economic objectives that were backed up by solid analysis. Through its WTO membership, Vietnam sought to improve 
access to leading export markets and to lock in domestic reforms with strong multilateral and legally binding commitments (Cling et al. 44).

Against this backdrop, Vietnam's accession negotiations are best understood in the context of its export-led growth strategy and alongside its bilateral and regional FTAs. Vietnam's integration into the global economy has been described as 'heterodox' in that although trade liberalization was significant, it was rather selective. Over the course of the late 1980s and 1990s Vietnam used a range of activist trade policies to support its export-led growth, including: import substitution measures; export subsidies; and, investment measures such as local content requirements and limits on the share of foreign ownership. In this way, Vietnam was able to protect key strategic export sectors, many of which were dominated by state-owned enterprises (SOEs), while also benefiting from foreign investment, technology transfer and expertise. ${ }^{20}$ From 1997 to 2007 , three major trade agreements came into force: the USBTA in 2000 , the AFTA in 2001 and finally Vietnam's WTO accession in 2007. While significantly improving access to key export markets, particularly for the garment industry that benefited from no longer being subject to quotas, these three agreements also required Vietnam to dismantle much of the infrastructure supporting its development model. More specifically, it had to reduce the scope of state intervention in the economy and phase out some of its more activist trade policy measures (Chaponniere and Cling 107-108).

Although there was broad support for WTO accession among Vietnam's leadership, the shift in policy orientation brought on by the USBTA and consolidated in Vietnam's WTO commitments was not without controversy. Witnessing Vietnam's

\footnotetext{
${ }^{20}$ For a more detailed summary of Vietnam's export-led growth strategy see Chaponniere and Cling (106108).
} 
increasing dependence on international trade, reformers saw continued integration into the global economy as a means of generating employment opportunities for the over one million new labor force entrants each year. This objective was particularly important to the Vietnamese Communist Party which, by this time, had come to realize that economic growth was increasingly becoming the source of its political legitimacy. Conservatives, on the other hand, feared that by forcing the government to limit its intervention in the economy, and in particular to curtail subsidies to SOEs, further reform would undermine the country's economic and political socialist foundations. The divide led to what some observers characterized as "perhaps the worst infighting and political deadlock Vietnam had experienced since reunification" (Mankin, Cooper and Gelb 17 $18)$.

The decision to sign the USBTA, which was delayed for more than a year after an agreement in principle had been reached, broke the political stalemate and led to a new policy consensus around further economic reform (Mankin, Cooper and Gelb 18-19). In addition to serving as a catalyst for domestic debate and consensus-building, the USBTA contains many provisions that closely reflect, and in some cases go beyond, WTO rules. Therefore, both from a political and a trade policy standpoint, the USBTA can be seen as an important stepping stone to WTO membership, and one that greatly facilitated Vietnam's rapid progress in accession negotiations from 2003 to 2006. The following paragraphs provide an overview of some of Vietnam's major WTO commitments, specifically those related to tariffs, trading rights, subsidies, TRIMS, services and antidumping. 
As a result of the USBTA and the AFTA, Vietnam's accession, at least in regard to tariffs, required only limited additional liberalization spread over an implementation period of up to 12 years (although most tariff reductions were phased in over five years). For example, on the eve of accession, Vietnam's average applied tariff was 17.4 percent. Its average final bound tariff, which comes into effect January 1,2019 , is only four percent lower at 13.4 percent (Cling et al. 45-46). In addition to being subject to modest and gradual tariff reductions, Vietnam secured the right to apply TRQs to imports of a small number of particularly sensitive agricultural products, namely, eggs, raw sugar, refined sugar, unmanufactured tobacco and salt (World Bank 2006 18). However, some sensitive tariff lines were subject to sharp reductions upon accession, including garments and beef, for which tariff rates declined from 37 percent to 14 percent and 80 percent to 65 percent, respectively. Other examples include meat products, footwear, air conditioners and television sets (15-16).

Some of the most significant trade liberalization brought about by Vietnam's accession came in the area of trading rights (the right to import and export). Over the course of the negotiations, working party members complained that the right to import required investment in Vietnam. Moreover, foreign-owned firms could only import goods used as inputs in final production or to establish a new enterprises. In contrast, locally owned firms were free to import final goods for resale (WTO "Working Party Report Vietnam" 35-36). These measures were important tools to promote foreign investment while also protecting locally owned firms. Upon accession, Vietnam agreed to lift all minimum capital requirements for firms engaged in trading activity and to permit all foreign individuals and firms to import and export, except for a limited number of 
products that remain subject to state trading (manufactured tobacco, petroleum, aircraft and culturally sensitive products such as newspapers and audio-visual material) (World Bank 2006 18).

As was the case with trading rights, Vietnam's use of subsidies to promote agricultural and industrial production and exports was heavily scrutinized by working party members. With respect to trade-distorting support to agricultural producers, Vietnam used a relatively recent base-period (1999-2001) that yielded a small final bound total AMS commitment level of 3.96 trillion dong or approximately US $\$ 250$ million. However, working party members agreed that Vietnam be considered a developing country under the provisions of the WTO Agreement on Agriculture (AoA), which granted it a 10 percent de minimis ceiling (WTO "Working Party Report Vietnam" 93). This allows Vietnam to exempt product-specific and non-product-specific trade distorting domestic support with an aggregate value of up to 10 percent of the annual value of production from its AMS calculations. ${ }^{21}$ In other words, this proportion of Vietnam's trade-distorting support does not count against its AMS commitment level and is not subject to scheduled reductions. While it is no stretch to consider Vietnam a developing country, it is interesting that Kyrgyzstan, which is considerably poorer than Vietnam, was only granted a 5 percent de minimis ceiling. Perhaps Vietnam's most important commitment in the agricultural industry was to bind export subsidies at zero upon accession, which is not a requirement for WTO members. Prior to accession, SOEs had accounted for a large portion of the purchasing and exporting of key agriculture products and benefited from various types of export subsidies, including interest rate support,

\footnotetext{
${ }^{21}$ In the case of product-specific support, the 10 percent threshold is derived from total value of production of the specific product to which the support is applied. In the case of non-product-specific support, the threshold is calculated based on the aggregate value of total agricultural production.
} 
export bonuses and support to cover losses. These types of subsidies were applied to a range of products including rice, coffee, pork, beef, chicken, canned vegetables and canned fruit (92-93). The elimination of such subsidies marked a major change for the agricultural industry.

Vietnam was also required to make some significant commitments to eliminate industrial subsidies. Paragraph 272 of the Report of the Working Party on the Accession of Vietnam includes an exhaustive list of the many industrial subsidies (including export subsidies) that Vietnam notified to the WTO during the 2003-2004 period. Some examples include: preferential import tariff rates contingent upon local content ratios with respect to products and parts of mechanical, electric and electronic industries; support for the implementation of projects manufacturing priority industrial products; investment incentives contingent on export performance for domestic and foreigninvested enterprises; and, support for development of the textile and garment sector. In the initial stages of its accession negotiations, Vietnam considered itself a low-income developing country, and on this basis suggested that it be allowed to maintain some prohibited subsidies, as provided for under Annex VII of the WTO Agreement on Subsidies and Countervailing Measures (ASCM) (WTO "Working Party Report Vietnam" 72). Working party members resisted this suggestion, but eventually agreed to grant Vietnam some flexibility in the form of a five-year transition period to phase out the payment of benefits to existing beneficiaries under programs that provided investment incentives contingent upon export performance for domestic and foreign-invested businesses. With this one exception, Vietnam agreed to eliminate all prohibited subsidies 
upon accession and to bring any remaining subsidies into conformity with the ASCM (74).

Vietnam's commitments on TRIMS are closely related to those on subsidies in that many of its pre-accession support programs, which offered preferential state credit or lower tariffs contingent on domestic content requirements and export sales ratios, were in contravention of both the ASCM and the TRIMS agreement. To address the concerns of working party members, Vietnam was required to submit a detailed action plan on the implementation of the TRIMs Agreement. Vietnam also committed to fully complying with the TRIMs agreement upon accession (WTO "Working Party Report Vietnam" 8586).

A particularly noteworthy area of the negotiations that led to some of Vietnam's most liberalizing commitments is trade in services. Prior to the implementation of the USBTA and its WTO accession, Vietnam significantly restricted trade in a number of key services sectors such as distribution services, telecommunication services and financial services (banking and insurance), among others. This was an important tool the government used to protect domestic enterprises, including many SOEs, in support of its import substitution strategy. Like Vietnam's many TRIMS, restrictions on trade in services, particularly in the banking sector, offered protection from foreign competition, but also contributed to the relatively low-proportion of foreign capital in the economy (Sam and Thu 2). As the political consensus around deeper global economic integration took shape, such restrictions were longer seen as desirable and Vietnam agreed to open its service industry to international competition. 
In the distribution sector, Vietnam committed to remove all restrictions on foreign-invested enterprises within three years of the date of accession. Thus, as of January 1, 2010, foreign companies were permitted to establish their own distribution networks, and engage in wholesale and retail business, as well as provide after sale services for all imported and domestically produced goods (World Bank 2006 19). This commitment, combined with those on trading rights, affords foreign-invested enterprises national treatment in the import, export and distribution of goods. Regarding basic telecommunications services, Vietnam agreed to permit joint ventures with up to 65 percent foreign capital for non-facilities based suppliers and 49 percent foreign capital for facilities based suppliers. ${ }^{22}$ For value-added telecommunications services (email, voice mail, data interchange) joint ventures for facilities based suppliers are limited to no more than 50 percent foreign capital (19). Despite some remaining limitations on foreign capital, Vietnam's commitments constitute considerable liberalization in a sector that is often considered to be of strategic value and remains heavily protected on a global scale.

Vietnam's commitments in the financial service sector are even more significant. In the insurance sector, Vietnam committed to allow 100 percent foreign-owned insurance companies to operate subsidiaries within its territory upon accession. Five years after accession, foreign insurance companies were permitted to open direct branches that sell non-life insurance. ${ }^{23}$ Vietnam's terms of accession also include a commitment to eliminate all restrictions on foreign company sales of insurance products within one year of the date of accession. Collectively, these and other commitments

\footnotetext{
${ }^{22}$ A non-facilities based supplier is one that does not own transmission capacity but contracts for such capacity from a facilities based supplier.

${ }^{23}$ Non life-insurance products include property insurance, casualty insurance, health insurance, as well as group policies, pensions and annuities.
} 
extend national treatment to foreign insurance companies operating in Vietnam (World Bank 2006 20).

Vietnam's commitments in the banking sector warrant a more detailed examination. Prior to accession, Vietnam's banking sector was dominated by state-owned commercial banks (SOCB), which accounted for over 70 percent of bank deposits and channeled most funds to SOEs (Tran 2). As part of its WTO commitments, effective April 2007, 100 percent foreign-owned banks were allowed to operate in Vietnam, subject to certain prudential requirements. To establish a 100 percent foreign-owned bank in Vietnam, the parent institution is subject to a minimum total asset requirement of US $\$ 10$ billion dollars. To establish a branch of a foreign commercial bank, the parent institution is subject to a minimum total asset requirement of US $\$ 20$ billion. As a result of these and other commitments, 100 percent foreign-owned banks now receive full national treatment with respect to the establishment of a commercial presence. Joint stock banks are also allowed, but subject to a 30 percent limit on foreign capital (World Bank 2006 19-20).

These commitments had immediate and profound effects on Vietnam's banking sector. In a direct sense, numerous large foreign investors acquired strategic stakes in Vietnamese joint stock banks very shortly after Vietnam acceded to the WTO. Some of the more notable investors include Hong Kong - Shanghai Banking Corporation (HSBC), the Overseas Chinese Banking Corporation (OCBC), the International Finance Corporation (IFC) and Sumitomo Mitsui Banking Corporation (SMBC), all of which own significant stakes in large Vietnamese joint stock banks. Although strategic investment in joint stock banks has so far proven to be the preferred market entry point, in 2007 HSBC 
and Standard and Charter opened fully-owned subsidiaries in Vietnam (World Bank 2009 75). Indirectly, the introduction of more foreign competition into Vietnam's banking sector has also served as a catalyst for commercially-oriented reforms to large SOCBs. In May 2006, a government policy was introduced to capitalize SOCBs by allowing them to sell up to sell up to 20 percent of their capital to strategic investors, including foreign investors. Some early adopters include Vietcombank, MHB, and Vientinbank BIDV (7374). As a result of these changes, by 2008 , only one year after accession, there were 83 commercial banks in Vietnam. Although SOCBs still accounted for a disproportionately large 48 percent share of total assets in the baking system, joint stock banks had already emerged with a 28 percent share of total assets and 95 percent growth in lending, relative to only 25 percent for SOCBs (77-78).

A final aspect of Vietnam's accession package that merits special attention is its designation as a 'non-market economy' for the purposes of anti-dumping and countervailing duty proceedings. This provision, which does not expire until December 31,2018 , provides WTO members with considerable methodological flexibility in assessing whether or not dumping has occurred and in measuring dumping margins in investigations against Vietnam (WTO "Working Party Report Vietnam" 6566). Because the WTO Anti-Dumping Agreement does not allow for this same type of flexibility for market economies, this particular commitment is widely considered to constitute a "WTO-minus" right. In other words, the "non-market economy" designation precludes Vietnam from access to a right that is available to other WTO members. In this particular case, the WTO right in question is that of anti-dumping investigations against a WTO member being subject to the prescriptive methodological requirements of the Anti- 
Dumping Agreement. The "non-market economy" provision was first devised during the 1960s in the context of Poland's accession to the GATT. In the WTO accession context, the provision was first applied to China, which joined the WTO five years prior to Vietnam's. A more detailed explanation of this provision and the concept of WTO-minus rights is presented in the China case study.

To summarize, although Vietnam's trade policies and practices were subjected to a high degree of scrutiny over the course of its lengthy WTO accession negotiations, the process was generally perceived as not being overly burdensome for Vietnam, or requiring excessively difficult concessions. Such perceptions owe largely to the fact that Vietnam's approach to economic reform and trade liberalization was very gradual and measured, spanning more than 20 years. By the time Vietnam reached the final stages of the accession process, it had already undergone significant trade liberalization under the AFTA and the USBTA and a strong political consensus in favor of deeper global economic integration had emerged. Reflecting this consensus, Vietnam agreed to farreaching WTO commitments that essentially dismantled much of the government's activist trade policy regime, including significant restrictions on trading rights and trade in services, as well as subsidies, TRIMS and other forms of support and protection for SOEs and domestic private enterprises.

\subsection{China}

China is destined to become a global economic super power. Its 1.3 billion inhabitants make it the world's most populous country, while its 9.5 million square kilometers make it the fourth largest in terms of land area. Efficiency gains resulting from gradual economic reform have contributed to a more than tenfold increase in China's 
GDP since 1978. With a GDP of US $\$ 10.09$ trillion, China now has the second largest economy in the world behind the US. Despite the ongoing global economic turmoil, China's outlook remains generally positive. Although demand for its exports fell for the first time in a number of years in 2009 , China rebounded quickly with a GDP growth rate of 10.3 percent in 2010, the highest of all major economies (CIA "China").

China's enormous labor force of 780 million (the largest in the world) has helped to make it the global leader in terms of the gross value of both industrial and agricultural output, which account for 46.8 percent and 9.6 percent of GDP, respectively. Services account for the remaining 43.6 percent of GDP. China ranks second to the US in terms of the value of services output (CIA "China"). Key agricultural outputs include rice, wheat, potatoes, corn, peanuts and tea among others. However, despite significant domestic production, the challenge of feeding 1.3 billion people requires significant food imports (US $\$ 67$ billion in 2010) that make China among the world's largest export destinations for agricultural and seafood products (Global Trade Atlas). Key industries include: mining and ore processing; iron, steel, aluminium, and other metals; coal; machine building; armaments; textiles and apparel; petroleum; cement; chemicals; fertilizers; and, consumer products such as footwear, toys and electronics. As a result of its growing output and increasing integration into the global economy, China became the world's largest exporter in 2010 , with total exports of US $\$ 1.6$ trillion (CIA "China").

Despite impressive growth and a positive economic outlook, China faces many challenges. Its per capita GDP of US $\$ 7,600$ ranks only $126^{\text {th }}$ globally and is below the world average. Over 21 million Chinese live below the absolute poverty line of US $\$ 90$ per year, and another 35.5 million live just above that, but below the official low income 
line of US $\$ 125$ per year. Sustaining job growth for hundreds of millions of new entrants to the labor market, including the flow of migrants from rural areas in the interior to more developed coastal areas, will be an ongoing challenge, and one that will be central to reducing poverty and mitigating social strife. Another systemic challenge for China is addressing the environmental repercussions of rapid economic development on an unprecedented scale. If not addressed effectively, air pollution, soil erosion, and the steady fall of the water table are problems that may become increasingly consequential for China in the coming decades (CIA "China"). Notwithstanding these challenges, for the purposes of the comparative analysis undertaken in this study, it should be underlined that China's GDP per capita is more than double those of Vietnam and Mongolia. Thus, in relative terms, China can be considered significantly wealthier than the other Asian countries being examined.

The founding of the People's Republic of China in 1949 ushered in three decades of orthodox communism marked by stagnation and poverty. The economic isolationism of this period was partially a backlash to China's old 'Open Door' policy imposed by the West, beginning in 1899. As it became clear that orthodox communism was failing as a development strategy, the increasingly pragmatic Chinese leadership, led by Deng Xiaoping, introduced the new 'Open Door' policy in December 1978. This new policy set the tone for China's economic transformation and the tremendous growth it experienced over the next 30 plus years. The new 'Open Door' policy differed fundamentally from the old one in that it was not imposed by western powers, but rather born out of the Chinese government's anxiety over prosperity and its desire for modernization (Kong 656). 
China's transformation from a centrally-planned economy to a market-oriented and globally integrated one bears many similarities to that of Vietnam, in that it was gradual, coherent and focused, but remains incomplete. ${ }^{24}$ Also like Vietnam, China's economic reform has yielded remarkable results. From 1978 to 2010, China's economy grew at an unprecedented annual rate of 9.5 percent, elevating hundreds of millions of people from absolute poverty (Brandt and Rawski "Thirty Years" 30). Further, although SOEs still play a dominant role in key strategic economic sectors such as finance, telecommunications, steel and petroleum, the private sector now accounts for 70 percent of China's GDP (Business Week). China's trade ratio (the combined value of imports and exports as a share of GDP) provides another useful illustrative tool. Prior to 1978 China's trade ratio was under 10 percent; by 1985 it had risen to 22.9 percent and then to 38.7 percent by 1995 . It finally peaked at nearly 65 percent in 2005 , a level that is far higher than any other large populous country (Brandt and Rawski “Thirty Years" 30).

China's reform process took place on two tracks: domestic and international. On the domestic front, reforms began with de-collectivizing agricultural production, the introduction of a dual pricing system and by allowing private businesses to operate. Eventually, as government power was decentralized, the private sector emerged, the dual pricing system gave way to a single market price and large-scale privatization occurred. The international dimension of China's economic reform is more pertinent to the present study and thus warrants a more detailed examination. Prior to the implementation of the new 'Open Door' policy, China's trade regime was dominated by as few as 10 SOEs that held monopolies over foreign trade. Planned import volumes were based on the projected

\footnotetext{
${ }^{24}$ This differs from many Eastern European countries, notably Russia, the Ukraine and Kyrgyzstan, which opted for a more dramatic 'shock therapy' approach.
} 
difference between domestic supply and demand, while exports were used simply to finance the required levels of imports. As import and export quantities were tightly controlled by SOEs, the pre-reform Chinese trade regime made little or no use of conventional trade policy measures (lanchovinchina and Martin 3).

In July 1986, China presented a note to the Director General of the GATT officially requesting to resume its status as a contracting party. China joined the WTO 15 years later in December 2001. By 1986, China was already nearly a decade into the new 'Open Door' policy. For this reason, China's accession negotiations and the broader process of economic reform should be seen as pieces of the same puzzle. In other words, to fully understand either requires a clear picture of both. The opening of China's economy to the world began in 1979 when a new law on joint ventures was passed, which for the first time elaborated terms under which foreign firms could operate in China (Bransteter and Lardy 11). Also in 1979, four 'special economic zones' (SEZs) were established in Guandong and Fujian. In 1984, the government created an additional 14 SEZs, mostly along China's Pacific coast. Foreign firms operating within the SEZs received preferential treatment with respect to taxes and various administrative procedures (11). Although initially small, SEZs soon became a driver of regional, and later, national growth (Brandt and Rawski "Thirty Years" 32). Two years later in 1986, China further liberalized its investment regime in a series of regulatory changes that gave foreign-invested enterprises increased managerial autonomy, made them eligible for lower corporate tax rates (regardless of their location), and most importantly, created a number of investment incentives for export-oriented projects and projects that upgraded domestic capacity through the use of advanced technology (Bransteter and Lardy 12). 
In parallel with the changes to its investment regime, China also made sweeping changes to its trade policy regime. Most notably, trading rights were extended to eventually include tens of thousands of SOEs controlled by the central government and regional and local governments. In 1984 these enterprises were made independent legal entities and, by the mid 1990s, operated on a strongly commercial basis. As trading rights were extended, strict central planning was supplanted by more traditional trade policy instruments such as tariffs, quotas and licenses. Exchange rate and commodity price distortions were reduced and eventually removed, allowing market forces to play an ever greater role in guiding resource allocation (Ianchovinchina and Martin 3-4).${ }^{25}$ Another significant feature of China's trade policy, which worked in tandem with its investment policy, was the extension of preferential import duties for products used in export processing, such that by 1987 all raw materials, parts, and components used in the production of goods for export could be imported into China duty free. Moreover, imports of capital goods have generally been duty free since the late 1970s, including imports by foreign-invested enterprises. As a result of these policies, by 2000, over 60 percent of China's imports were duty free (Bransteter and Lardy 5-6).

Through the investment and trade policy measures described in the preceding paragraphs, China successfully attracted foreign investment and pursued a strategy of export-led growth, while significantly upgrading domestic production capacity and competitiveness; in essence, modernizing its economy. With this context in mind, and

\footnotetext{
${ }^{25}$ The main tool used to phase out exchange rate and price distortions was a two-tier pricing system under which producers were contracted to supply a specific quantity of the commodity in question at the planned price, but could also supply additional output at a secondary market price. By 1994 the gaps between planned prices and market prices had been gradually eliminated and the two-tier pricing system gave way to a single market price. See World Bank, 1994 for details. However, it should be noted that the exchange rate remains an important tool of China's trade policy. Many countries, including primarily the US, have long claimed that China maintains an undervalued exchange rate in order to promote exports.
} 
recalling that a significant portion of the trade liberalization China underwent in the 1990s was, in effect, part of the accession process, the following paragraphs provide an overview of China's accession negotiations and its key WTO commitments.

A unique feature of China's accession negotiations is that China was one of the original contracting parties of the GATT. However, when the PRC was founded in 1949, the previous Chinese government, based in Taiwan, was informed that preferential tariff rates would not be extended to Taiwan as it no longer controlled mainland China, and thus, could not perform its GATT duties. Not wanting the PRC to benefit from GATT preferences, effective May 5, 1950, Taiwan withdrew from the GATT in the name of the Republic of China. As explained succinctly by Yang Guohua, former Deputy Director at the Department of Treaty Law in China's Ministry of Foreign Trade and Economic Cooperation, the Chinese government contends that "although Taiwan's withdrawal from the GATT followed the prescriptive procedures, it was illegal and invalid because the government of the Nationalist Party (Kuomindang, or KMD) had no right to represent China from 1 October 1949" (Guohua and Jin 299) ${ }^{26}$ On this basis, and as previously alluded to, China did not technically apply to join the GATT in 1986. Rather, it notified members of its intention to resume its status as an original contracting party. Not wanting to miss an opportunity to negotiate potentially lucrative market-access concessions with an emerging economic power, GATT members did not take to this idea. While maintaining its position on the illegality of its withdrawal from the GATT, China

\footnotetext{
${ }^{26}$ Guohua further explains: "The Common Program passed by the First Session of the Chinese People's Political Consultative Conference on 29 September 1949, stated that 'for all treaties and agreements which were signed by KMD and foreign governments, the People's Central Government of the PRC should examine them and respectively admit, abolish, revise or remake according to their contents.' This meant that the validity of all old treaties was uncertain. They had to be examined and decided, one by one, according to the contents of each treaty or agreement."
} 
eventually agreed to negotiate the terms of membership in recognition of its long absence from GATT negotiations and the incompatibility of its trade laws and regulations with GATT rules (304).

The 1989 Tiananmen Square massacre was another early setback for China's accession effort. The world-wide attention paid to this event had a distinctly chilling effect on relations between Beijing and most western powers, which effectively froze substantive progress in the negotiations until the mid-1990s. From 1996 to 1998, the working party met with great regularity and made substantial progress. Negotiations again faltered in late 1998 and during the first half of 1999, when both the US and China became frustrated at their failure to reach a bilateral market-access agreement (Bhala 1497-1505). The China-US bilateral market-access agreement of November 15, 1999 served as a catalyst for the final push toward accession. The working party intensified its efforts from late 1999 until the final meeting in January 2001.

Over the course of accession, and particularly in bilateral negotiations with the US, China agreed to a set of commitments that were far more exacting than what had previously been asked of developing countries, or any acceding country for that matter. Although, in some respects China's commitments are more liberalizing than those of any other WTO member, such commitments should not be interpreted solely as resulting from Chinese negotiators succumbing to pressure from working party members. As many observers have noted, by the time China had reached an advanced stage in the accession process, its senior political leadership had come to believe that WTO membership was an indispensable component of its reform agenda. This viewpoint was articulated publicly by Premier Zhu Rongji on the occasion of his April 1999 visit to the White House. In a 
joint press conference with President Clinton, he stated that, "The competition arising [from WTO membership] will also promote a more rapid and more healthy development of China's national economy" (Bransteter and Lardy 21). In other words, Premier Zhu and the leadership cadre believed that the best policy option for China was to pursue further integration into the global economy. They saw that increased competition associated with further economic integration would help to further modernize China's economy by, among other things, forcing SOEs and banks to undergo further structural reforms (21). It has also been suggested that President Jiang Zemin wanted WTO membership, and the closer partnership with the US that this would entail, to define his political legacy (Bhala 1511). Indeed, political leaders in key WTO member countries also took a strong interest in the negotiations, including, President Clinton, who in the words of the Financial Times was "desperately trying to forge a historical legacy that goes beyond sex scandal" (1511).

Despite the senior-level political push for accession, the consensus around further economic integration was not unanimous among China's political elite or within the state bureaucracy. The army feared losing control of the telecommunications sector, and many SOEs and banks, still ailing from the Asian economic crisis of the late 1990s, feared collapse under the weight of foreign competition. These were serious concerns. At the time, SOEs employed over 65 percent of the urban workforce and provided an extensive social safety net, including access to heath care and other benefits (Bhala 1490-1492). Beyond economic matters, China's system of government had also become a central question. In its November 20, 1999, issue, entitled "China Opens Up", The Economist questioned "Whether Chinese Communism will be strengthened by [WTO] membership - 
as China's leaders must hope - or be ruined by it." The article goes on to explain that, as a result of China's WTO commitments, "the state sector, the bastion of the Communist Party's power, will everywhere be undermined." Despite these concerns and others, reformers eventually held sway. As The Economist aptly remarks, “...the Communist Party has made a calculation about how best to stay in power. Delivering prosperity, Party members acknowledge, is now the touchstone of its legitimacy..."

Beyond the broad goal of promoting prosperity, China's WTO accession had more specific objectives. First, China sought to expand international trade. By the early 1990s, 90 percent of China's trade was with GATT members. However, China could not secure unconditional MFN status from the US, nor could it benefit from GATT rules that provided for a fair, predictable and stable trading environment. In this regard, China was particularly interested in protecting itself from unilateral protectionist measures such as quantitative import restrictions on Chinese products and unfair anti-dumping measures. Second, China sought to deepen its participation in international economic affairs, including the formulation of trade rules (Kong 659-653). In this sense, China's WTO accession can be seen as following from the 1980 restoration of its seats in the IMF and the World Bank. ${ }^{27}$

The terms of China's accession to the WTO include a number of significant liberalizing commitments in a broad range of areas. For the purposes of this study, we focus on: tariffs, trading rights, TRIMS, subsidies, TRIPS, services, the textile safeguard, the product-specific safeguard and anti-dumping measures. A distinguishing cross-cutting feature of China's accession package is the inclusion of various commitments that result

\footnotetext{
${ }^{27}$ For a more detailed account of the specific objectives of China's WTO accession see Guohua and Jin (302-304) and Kong (659-653).
} 
in 'WTO-plus' obligations and 'WTO-minus' rights. In essence, China agreed to obligations that exceed the requirements of the WTO agreements (WTO-plus) and that reduce its rights as a WTO Member (WTO-minus). Prior to China's accession, WTOplus provisions were uncommon and relatively inconsequential, while WTO-minus provisions had never been applied. As discussed in chapter three, determining what specifically constitutes a WTO-plus obligation or a WTO-minus right can be subject to different legal interpretations of WTO rules. As a result, such exercises are not without controversy. As this issue is largely ancillary to the central question being explored in this paper, the following paragraphs do not attempt to make a determination as to which of China's commitments constitute WTO-plus obligations. For present purposes, it is sufficient to know that China agreed to a far greater number of such obligations than any other WTO member. ${ }^{28}$ In contrast, China's WTO-minus rights are virtually self-evident and mark a unique departure from accession precedents. Consequently, a brief overview of such obligations is included in the following analysis.

In terms of tariffs, China began the liberalization process well before it applied to resume its status as a GATT contracting party. Between 1982 and 2000 (the year prior to accession) China underwent several rounds of unilateral tariff reductions resulting in a gradual decrease of its average applied tariff from 55.6 percent to 16.4 percent. This unilateral liberalization resulted in significant reductions in the dispersion of tariff rates, from a standard deviation of 29.9 in 1992 to less than 10 percent, and reductions in the maximum tariff from 220 percent to 65 percent (Rumbaugh and Blancher 18). As previously mentioned, because of China's many SEZs and duty preferences or exemptions for goods used in export processing, by 2000,60 percent of China's imports

\footnotetext{
${ }^{28}$ For detailed analysis of China's WTO-plus obligations and their implications, see Qin (2003).
} 
entered either duty free or at reduced rates. Although unilateral tariff reductions were in line with China's broad economic reforms, some observers note that they were also designed to add to China's credibility at the negotiating table and send a signal to WTO members that it was committed to the accession process (Bransteter and Lardy 20). Because of these gradual reforms, China's accession commitments did not involve abrupt or particularly difficult tariff concessions. Its final commitments, of which most were in effect by 2005 , include average bound tariffs of 15.7 percent on agricultural products and 9.2 percent on industrial products for an overall average of 10 percent. Other notable changes to China's import measures include the phase-out or immediate tariffication of quantitative import restrictions (WTO "Working Party Report China" 21-26). In consequence, China now maintains TRQs on only a limited number of import products including: certain grains; certain vegetable oils; sugar; cotton; wool and certain chemical fertilizers (WTO "Schedule CLII China").

In parallel with its commitments on quantitative import restrictions, China agreed to continue to progressively liberalize the availability and scope of trading rights. Although China had been expanding foreign trading rights since the $1980 \mathrm{~s}$, on the eve of accession, the right to import and export goods was still only available to some domestic enterprises (totaling 35,000) and foreign-invested enterprises that sought to import primary and capital goods for export processing. Upon accession to the WTO, China committed to eliminate its practice of tightly regulating trading rights so that within three years all Chinese and foreign enterprises and individuals would have the right to export and import all goods, except for a limited range of products that would remain subject to state-trading. In addition to those listed in the preceding paragraph, such products include, 
among others: tea; rice; corn; soy beans; cotton; silk; crude and processed oil; tungsten; and ammonium (WTO "Working Party Report China" 15-17).

Although the section of China's working party report that deals with TRIMS is short (less than one page in length), its significance should not be understated. In agreeing to fully comply with the TRIMS Agreement upon accession, and without recourse to Article 5 that allows for transitional measures, China agreed to the immediate elimination of many of the more interventionist tools of its export-oriented industrial policy. For example, the provisions of the TRIMS agreement do not allow for the use of local-content requirements, trade-balancing requirements, foreign-exchange balancing requirements, export-performance requirements and technology-transfer requirements, all of which were features of China's pre-accession investment regime. Moreover, China agreed not to enforce the terms of existing contracts that contained such requirements (WTO "Working Party Report China" 40).

Also of consequence for China's industrial policy were its commitments on subsidies. Upon accession, China agreed to eliminate all prohibited subsidies under the SCM Agreement, which include subsidies contingent on export performance and subsidies contingent on local content. With respect to actionable subsidies, China committed to reduce their availability, in particular by reforming its tax system and making SOEs, including banks, operate on a commercial basis, making them fully responsible for their own profits and losses (WTO "Working Party Report China" 33-34). Regarding subsidies to agricultural producers, although China agreed to a nil final bound total AMS commitment, it secured a de minimis ceiling of 8.5 percent of the value of production for both product-specific and non-products specific support (44). This is 
significant because China had sought consideration as a developing country under the terms of the AoA, which would have resulted in a de minimis ceiling of 10 percent. Although working party members did not ultimately agree to this request, the 8.5 percent de minimis ceiling represents a unique and unprecedented compromise, given that the level prescribed for developed countries is 5 percent. Another notable aspect of China's commitments on trade-distorting domestic support is the agreement to forgo use of Article 6.2 of the AoA, which reserves the right for developing countries to exempt certain types of trade-distorting support (investment and input subsidies) from reduction on the grounds that they play an important role in rural development (Brink 6).

Although China's WTO commitments pertaining to TRIPS are not especially contentious or precedent setting, it was a difficult area of the negotiations. This is reflected in the fact that 15 of the 71 pages (not including annexes) of the working party report on the accession of China are dedicated to this topic. Along with Russia, China consistently ranks among the world's worst violators of intellectual property rights and is widely know as a haven for piracy and counterfeiting. Consequently, TRIPS was a priority negotiating area for many working party members, most notably the US. In an effort to address members' concerns, China undertook extensive legal reform and committed to fully applying the provisions of the TRIPS agreement upon accession. In general terms, this involved: meeting minimum standards of protection for copyrights and neighbouring rights, trademarks, geographical indications, industrial designs, patents, integrated circuit layout designs and undisclosed information; meeting minimum requirements for the enforcement of intellectual property rights, administrative and civil actions and, with respect to copyright piracy and trademark counterfeiting, in criminal 
actions and actions at the border; and, applying national treatment and MFN treatment to foreign right-holders regarding all intellectual property rights (WTO “Working Party Report China" 48-63). Despite an overhaul of China's laws and regulations on the protection of intellectual property rights, effective enforcement remains a significant challenge and improving the protection of intellectual property rights remains an important area of focus in US-China trade relations. ${ }^{29}$

One of the more groundbreaking aspects of China's accession negotiations was its commitments on services. Prior to accession the services industry had been largely closed to foreign competition. China's schedule of specific commitments on services includes measures to open all service sectors covered by the General Agreement on Trade in Services to foreign investment and competition. Commitments in distribution services, telecommunication services and financial services are particularly important and thus warrant further explanation. Notwithstanding the special focus on these three sectors, China also made important commitments in a range of professional services (including legal, accounting and real estate services among others), tourism and travel related services, and transportation services among others.

In regard to distribution services, China agreed to extend distribution rights to Chinese-foreign joint ventures, wholly foreign-owned enterprises and foreign individuals for both agricultural and industrial goods within three years from the date of accession. Foreign firms operating in China are now able to establish their own distribution networks, as well as maintain wholesale and retail operations, including providing after-

\footnotetext{
${ }^{29}$ For details, see the Office of the US Trade Representative's (USTR) 2011 review of the global state of intellectual property rights (IPR) protection and enforcement (Special 301 Report), available at: http://www.ustr.gov/about-us/press-office/reports-and-publications/2011
} 
sale service (Bhala 1513). Prior to accession the right to provide such services was limited to Chinese companies, which often made it cumbersome for foreign firms and individuals to distribute their products in China. At the time, the scope of China's commitments to liberalize distribution services prompted former US Trade Representative Charlene Barshefsky to characterize them as "broader actually than any World Trade Organization member has made" (Bransteter and Lardy 30). As was the case with Vietnam, China's commitments in distribution services were complementary to its commitments to liberalize trading rights, so as to extend national treatment to foreign firms and individuals for to the importation, exportation and distribution of goods.

In telecommunications services, China agreed to gradually ease restrictions on foreign direct investment by allowing foreign enterprises to take up to a 49 percent stake in the ownership of joint ventures providing basic services and a 50 percent ownership stake for joint ventures providing value-added services. Depending on the specific type of telecommunication service in question, some of these commitments came into effect upon accession, while others were phased in over periods of two, five or six years. In addition, China committed to opening its most important telecommunications corridor (the Beijing - Shanghai - Guangzhou Region) to foreign-invested enterprises providing all telecommunications services, and to lifting all remaining geographic limitations on the provision of such services within six years from the date of accession. Finally, and perhaps most significantly, China joined the WTO Basic Telecommunications Agreement and thereby agreed to implement its pro-competitive regulatory principles, such as costbased pricing, interconnection rights and the establishment of an independent regulatory authority (Bhala 1513). Despite these commitments, even now, 10 years after China's 
accession to the WTO, foreign participation in its telecommunications market remains very limited. As noted in the USTR's 2011 National Trade Estimate Report on Foreign Trade Barriers, "China's regulator for the sector, MIIT (the Ministry of Industry Information and Technology), while nominally separate from current telecommunications operators, maintains extensive influence and control over their operations and the overall structure of the market" (USTR "Trade Estimate Report" 77-78). As a result, investment approval procedures are often lengthy and lack transparency. This factor, combined with the aforementioned foreign equity restrictions, has limited commercial opportunities in the sector.

China's most significant commitment in financial services was to extend full national treatment to foreign banks within five years of the date of accession. Thus, subject to certain requirements (considered to be prudential), since the end of 2006 foreign banks have been allowed to establish subsidiaries branches anywhere in China and offer full domestic currency services to Chinese citizens (USTR "Trade Estimate Report" 73-74). In consequence of this market opening, by the end of 2010, 35 foreignowned banks had incorporated in China and been granted approval to conduct renminbi business. In addition, there were 360 foreign banks operating in China accounting for 1.83 percent of total assets (Metcalfe 14). Despite the significant market opening, the relatively low market penetration by foreign banks reflects remaining administrative barriers that make it difficult to compete with domestic banks in terms of offering a full range of banking services (USTR "Trade Estimate Report" 73-74).

Other important commitments in financial services came in the insurance sector. For example, China agreed to phase out all geographic restrictions on where foreign 
insurance companies could do business within five years of the date of accession. Moreover, effective upon accession, foreign insurance companies were allowed to take up to a 50 percent equity stake in Chinese life insurance companies and a 51 percent stake in non-life insurance companies (Bransteter and Lardy 33).

The three remaining aspects of China's accession package examined below, the textile safeguard, the product-specific safeguard and the commitments relating to antidumping measures, collectively account for China's WTO-minus rights. In essence, these commitments preclude China from benefiting from certain rights available to other WTO members. Such commitments stem from working party members' desire to protect domestic producers from potential harm that could result from increased imports from China. They are protectionist measures that specifically target China, based on its perceived economic clout and exporting prowess.

With respect to textiles, China agreed to a special safeguard that allowed WTO members to limit growth in imports of textile and apparel products of Chinese origin to a level no greater than 7.5 percent per year. Members could apply the safeguard, in consultation with China, if they deemed that imports of Chinese textiles and apparel were causing "market disruptions" that threatened to impede "the orderly development of trade in these products" (WTO "Working Party Report China" 45-46). Notably, the special safeguard on textiles remained in place until December 31,2008, three years after the phase out of the WTO Agreement on Textiles and Clothing that brought an end to the use of quotas to limit trade in textiles and apparel. Beyond textiles, China agreed to a broader product-specific safeguard that authorizes WTO members to impose quantitative restrictions against imports of any product from China that causes or threatens to cause 
significant "market disruption" or "trade diversion" (46-48). The conditions under which members can apply this safeguard differ from those in the WTO Agreement on Safeguards in that they are significantly less demanding. First, restrictions can be applied solely on imports of Chinese goods, even when imports of the same product from other countries have increased. Under the Agreement on Safeguards, restrictions must be applied on an MFN basis to like imports from all exporting countries. Second, the standard for determining injury based on which the product-specific safeguard can be invoked - "market disruption" - is considerably less rigorous than the "serious injury" standard used in the Agreement on Safeguards. Moreover, once the product-specific safeguard has been applied it can be extended indefinitely, whereas the Agreement on Safeguards stipulates an eight-year limit. The product-specific safeguard will remain in place until 2013, 12 years after China's accession to the WTO.

In regard to anti-dumping measures, China agreed in its accession protocol to be considered a "non-market economy" for the purposes of anti-dumping and countervailing duty proceedings. As we have seen, this same provision was later applied to Vietnam. This provision gives WTO members greater flexibility in making a determination of dumping against China. For the purposes of determining the "normal value" used to assess dumping margins, WTO members can use "a methodology that is not based on a strict comparison with domestic prices or costs in China if the producers under investigation cannot clearly show that market economy conditions prevail in the industry...” (WTO “Accession Protocol China" 8-9). In practice, this usually results in WTO members using a proxy price from some surrogate country or a constructed price. As one legal expert explains: 
Because China's comparative advantages mostly derive from the low costs of its factors of production, this provision makes it more likely for other WTO Members to arrive at a higher normal value and thus makes it easier for them to reach a determination of the existence of dumping (Gao 15).

This argument seems to be supported by the fact that from 1995 to 2010 China was the subject of a reported 784 anti-dumping investigations, of which 563 resulted in a determination of dumping. In other words, an affirmative determination of dumping was reached in 72 percent of cases. Over the same timeframe 2968 dumping investigations were initiated against all other WTO members, of which 1870 resulted in a determination of dumping. This yields a rate of affirmative determination of only 63 percent (WTO "Anti-Dumping Gateway"). The application of the "non-market economy" anti-dumping provision is scheduled to expire in 2016,15 years after WTO accession.

To summarize, China's accession to the WTO was a long and often arduous process. Although China had undergone major economic reform and unilateral trade liberalization since the adoption of the new 'Open Door' policy in 1978, working party members' demands for more trade liberalization were a source of considerable political debate in China. In the end, China's senior political leadership made a calculation that the legitimacy of its regime rested on its ability to promote prosperity and development, and that continued integration into the global economy was the best course of action in pursuit of these objectives. For this reason, Chinese negotiators eventually accepted the substantial demands of working party members for market opening. An accession package that undid many of the remaining vestiges of China's state-run economy and set a new benchmark in trade liberalization was adopted. A particularly distinguishing feature of China's broad WTO commitments in areas such as trading rights, TRIMS, 
subsidies, distribution services and safeguards, is the inclusion of WTO-plus obligations and WTO-minus rights. These commitments have been subject to fierce criticism in some circles. For example, noted expert on China's accession, Nicholas Lardy, describes the terms of China's accession as "so onerous that they violate the fundamental principles of the WTO" (9). While it makes for an interesting point of debate, this question is largely academic since these types of obligations were not widely replicated in following accession negotiations and are unlikely to be seen in the future, with ever fewer large economies remaining outside of the WTO.

The one accession where many of China's so-called WTO-plus and WTO-minus provisions were replicated is Vietnam's. Indeed, Vietnam's commitments on trading rights, services and anti-dumping measures seem to closely mirror those of China. In this sense, Vietnam's path to WTO membership may have been made considerably more difficult by the precedent set by China in terms of trade liberalization. However, Vietnam's commitments on tariffs, WTO rules and safeguards do not go as far as China's. Mongolia, in contrast, underwent a relatively rapid and painless accession process. Despite some serious procedural limitations in consultations with domestic industry, Mongolia's trade liberalization has helped to attract significant foreign investment and stimulate consistent economic growth. On balance, a comparison of Mongolia, Vietnam and China's accession offers clear support for the main hypothesis of this paper in that commensurate with their relative economic size and trade levels each was subjected to progressively more scrutiny from WTO members and required to undergo more trade liberalisation in the accession process. 


\section{CASE STUDIES: PART 3 - MIDDLE EASTERN COUNTRIES}

As discussed in chapter four, a possible source of bias in the preceding case studies is that the sample is comprised entirely of transition economies. As we have seen, transition economies face some unique challenges in the accession process that may bear some influence on research findings. In order to address this issue and test the broader applicability of research findings, this chapter presents a brief examination and comparison of the accession negotiations of two non-transition economies: Jordan and Saudi Arabia. These countries should provide a good basis for analysis as both are located in the Middle East and one has a large economy while the other has a relatively small economy. In addition, 8 of the 30 countries currently seeking WTO accession are from the Middle East and North Africa region which should help contribute to the generalizability of the research findings. Tables $8(a),(b)$ and (c) present the quantitative data associated with each country's accession.

Table 8(a) - Economy Size, Trade, Value and Diversity in the Year of Accession

\begin{tabular}{l|r|r}
\hline \multicolumn{1}{c|}{ Country } & Jordan & \multicolumn{1}{c}{$\begin{array}{c}\text { Saudi } \\
\text { Arabia }\end{array}$} \\
\hline \hline Year of WTO Accession & 2000 & \multicolumn{1}{c}{2005} \\
\hline Economy Size (GDP in US\$ billions) & 8.5 & 315.6 \\
\hline Total Trade Value in the Year of Accession (US\$ billions) & 6.5 & 240.2 \\
\hline Trade Diversity in the Year of Accession & 18 & 64 \\
\hline
\end{tabular}

Table 8(b) - The WTO Accession Process

\begin{tabular}{l|r|r}
\hline \multicolumn{1}{c|}{ Country } & Jordan & \multicolumn{1}{c}{$\begin{array}{c}\text { Saudi } \\
\text { Arabia }\end{array}$} \\
\hline \hline Number of Working Party Members & 30 & 47 \\
\hline Number of Working Party Meetings (days) & 5 & 20 \\
\hline Page Length of the Report of the Working Party & 69 & 135 \\
\hline Overall Negotiating Scrutiny & 104 & 202 \\
\hline
\end{tabular}


Table 8(c) - Negotiating Outcomes

\begin{tabular}{l|r|r}
\hline \multicolumn{1}{c|}{ Country } & Jordan & $\begin{array}{c}\text { Saudi } \\
\text { Arabia }\end{array}$ \\
\hline Average Final Bound Tariff (ad valorem) & 16.3 & 11.8 \\
\hline Number of Specific Service Sub-sector Commitments & 110 & 120 \\
\hline Number of Commitments on WTO Rules & 29 & 59 \\
\hline Overall Trade Liberalization & 122.7 & 167.2 \\
\hline
\end{tabular}

\subsection{Summary of Quantitative Data}

Quantitative data related to Jordan's and Saudi Arabia's WTO accession negotiations is consistent with the hypothesis put forth in this paper and the research findings for transition economies. As displayed in the tables above, according to every measure, Saudi Arabia is a bigger player than Jordan in the global economy.

Correspondingly, and again according to every measure, Saudi Arabia was subjected to more negotiating scrutiny than Jordan and agreed to more trade liberalization in its WTO commitments. Also in line with previous findings, the measures of economy size, trade value and trade diversity appear more strongly correlated with negotiating scrutiny than with trade liberalization. These results suggest, at least in a general sense, that the research findings presented in this paper are equally applicable to transition and nontransition economies. As an additional basis for comparison table 8(d) shows the values for the independent variables as well as the overall negotiating scrutiny and trade liberalization scores for all of the countries included in the case study. Again, this table shows that transition and non-transition economies follow the same general trend with scores for negotiating scrutiny and trade liberalization rising in parallel with measures of economy size, trade value and trade diversity. Saudi Arabia's low negotiating scrutiny score relative to those of Ukraine and Vietnam, which have considerably smaller 
economies, stands out from this general trend. This likely has to do with Saudi Arabia's low trade diversity score and limited potential as an export competitor to WTO members. As discussed in more detail below, Saudi Arabia's economy is highly dependent on petrochemicals.

Table 8(d) - Economy Size, Trade Values, Trade Diversity, Negotiating Scrutiny and Trade Liberalization (monetary values in USS billions)

\begin{tabular}{l|r|r|r|r|r}
\hline Country & $\begin{array}{c}\text { Economy } \\
\text { Size in the } \\
\text { Year of } \\
\text { Accession }\end{array}$ & $\begin{array}{c}\text { Total Trade } \\
\text { Value in the } \\
\text { Year of } \\
\text { Accession }\end{array}$ & $\begin{array}{c}\text { Trade } \\
\text { Diversity in } \\
\text { the Year of } \\
\text { Accession }\end{array}$ & $\begin{array}{c}\text { Overall } \\
\text { Negotiating } \\
\text { Scrutiny }\end{array}$ & $\begin{array}{c}\text { Overall Trade } \\
\text { Liberalization }\end{array}$ \\
\hline Mongolia & 1.1 & 0.9 & 1 & 52 & 19.5 \\
\hline Kyrgyzstan & 1.6 & 1.1 & 2 & 87 & 139.5 \\
\hline Jordan & 8.5 & 6.5 & 18 & 104 & 122.7 \\
\hline Vietnam & 68.6 & 11.3 & 72 & 250 & 161.6 \\
\hline Ukraine & 180.4 & 152.5 & 47 & 294 & 194.2 \\
\hline Saudi & 315.6 & 240.2 & 64 & 202 & 167.2 \\
\hline Arabia & 1324.8 & 509.8 & 92 & 269 & 229 \\
\hline China & 1477 & 560 & 85 & 694 & 286.8 \\
\hline Russia & & & & & \\
\hline
\end{tabular}

\subsection{Jordan}

Jordan is a small, mostly arid country in the Middle East with a population of approximately 6.5 million. It shares borders with Saudi Arabia, Israel, Syria and Iraq. Jordan has one of the smallest economies in the region and is also among the poorest countries with a GDP per capita of US $\$ 5,400$. The country suffers from an acute shortage of water, oil and other natural resources. This factor, coupled with chronic poverty, unemployment, inflation and large budget deficits, makes the government heavily reliant on foreign assistance. Key industries include textiles, fertilizer, potash, phosphate mining, pharmaceuticals and tourism. Jordan also produces a variety of fruits and vegetables. Despite its economic challenges and being located in a particularly 
volatile region, Jordan has remained relatively politically stable since its independence from Britain in 1946. Jordan is a constitutional monarchy with historically pragmatic, moderate and benevolent political leadership. This has enabled Jordan to become a strategic ally of the US and other western countries in the Middle East and helped the government to secure much of the foreign aid on which it depends (CIA "Jordan").

In the late 1980s Jordan underwent a severe economic crisis that forced the government to seek support from the IMF and the World Bank. The loans Jordan received were linked to the adoption of a comprehensive structural adjustment program based on free-market principles and involving significant trade liberalization. Jordan received considerable support in the reform process from USAID and the German Agency for Technical Assistance, among other bilateral donors (al Khouri 179-180). By the mid 1990s, promoting growth through increased trade and integration into the global economy had become a core element of the government's long-term economic strategy. It saw WTO accession as a means of improving access to export markets and giving consumers access to better and cheaper products. Jordan's leadership also sought the political prestige associated with becoming a WTO member (Malkawi 2-3). Other observers report that the Jordanian government saw WTO accession as a means of attracting much needed foreign direct investment (al Khouri 179).

Jordan applied to join the WTO in April 1994 and became a WTO member six years later in April 2000. Jordan's accession bid benefited from strong diplomatic support from the US and the EU stemming from the signing of a peace accord with Israel in October 1994 (al Khouri 178). Despite being the recipient of significant technical assistance, Jordan struggled with many of the same issues faced by other small 
developing countries in their accession negotiations. Both the public and private sectors lacked expertise in international trade negotiations and knowledge of WTO rules. Even with the establishment of a joint government-industry advisory committee and the organization of various public consultations and seminars, dialogue was not particularly constructive and broad-level stakeholder input was not always effectively incorporated into the negotiating process, at least in its early stages. While the government no doubt bears some responsibility for this, in many cases Jordanian industry groups lacked the capacity to articulate and represent their interests and were prone to dogmatic anti-WTO propaganda (182-185). However, as the negotiations proceeded engagement of non-state actors, particularly chambers of commerce, significantly improved and, in effect, motivated the government to commit more resources to the accession process and dedicate more time to accession-related issues in cabinet meetings (190). Other weakness in the process included rivalries among implicated ministries, including the Ministry of Planning and International Cooperation, the Ministry of Industry and Trade and the Ministry of Finance, and the cynicism and lack of involvement of the Jordanian parliament (186-187).

The most challenging aspect of WTO accession for Jordan pertained to TRIPS, liberalization of the service industry and liberalization of the agriculture industry. Strengthening Jordan's IPR regime was the US's main negotiating priority. Prior to accession, protection for trade marks and patents was virtually non existent in Jordan. Jordanian law allowed for trademarks to be registered in Jordan on a first-come-first serve basis with no regard for previous usage. This resulted in many Jordanian companies registering well-known international trademarks such as "Pillsbury" and "7-Eleven." 
With respect to patent law, problems were particularly acute in the pharmaceutical sector, where it was estimated that unauthorized production of generic drugs cost US companies between US $\$ 25$ and $\$ 50$ million in annual loses. In order to address these issues, Jordan made a commitment to comply fully with the TRIPS agreement. To fulfill this commitment Jordan implemented a new trademark law in 1999 and significant changes to its patent law in 2001. In addition, the Jordanian government took a series of measures to strengthen the enforcement of its IPR regime (Malkawi 13-16). Although enforcement remains a challenge, the measures taken by the Jordanian government were sufficient to prompt the US to remove Jordan from its IPR watch list and recognize it as a regional leader in IPR protection (al Khouri 199).

Jordan's commitments on services are relatively broad in terms of their sector and sub-sector coverage, and in this respect, are very much on par with the majority of other accessions. However, Jordan's commitments are also rather shallow and leave a lot of scope for the government to protect certain sub-sectors from foreign competition. Jordan's most significant market-opening commitments came in telecommunications where the previously government-controlled sector was opened to unfettered foreign competition. Foreign service providers now receive national treatment in Jordan for the full range of basic and value-added telecommunication services. Foreign participation in other major service sectors such as distribution, insurance and banking remains subject to various types of restrictions. Some examples included restrictions on the type of commercial presence (i.e. branches, subsidiaries or joint-ventures), restrictions on the types of services offered (i.e. business lines) and restrictions on limits on foreign equity (Malkawi 9-12). 
As with many countries, a number of Jordan's most difficult reforms and market access commitments came in the agriculture industry. The two biggest structural reforms were the abolition of the Agricultural Marketing Organization, which held a monopoly over importing and exporting, and the abolition of fixed prices for agriculture products. Although these reforms were part of Jordan's structural adjustment program, they were also important pre-conditions for WTO membership (Malkawi 6). On the issue of tradedistorting domestic support, Jordan agreed to reduce AMS levels by 13 percent, yielding a final bound commitment level of 1.334 Jordanian Dinar (or approximately US $\$ 1.8$ million). As a developing country, Jordan has a 10 percent de minimis exemption and is able to use Article 6.2 of the AoA that allows it to further exempt certain types of support for development purposes (Brink 4-6). Collectively, these commitments greatly reduced government's role in agriculture, and in effect changed the nature of the industry from a heavy reliance on government support, to a more commercial orientation.

With respect to market access, Jordan was forced to eliminate import quotas on olive oil, chicken and other meats and was unable to secure special safeguards for these products (Malkawi 6-7). However, on balance, tariff reductions were not overly onerous. Jordan's average final bound tariff for agriculture products is relatively high at 23.6 percent. In addition, for a number of sensitive products, including a large proportion of meats, vegetables, fruits, nuts and products thereof, tariff reductions were implemented very gradually over 10-year staging periods (WTO "Schedule CLXVIII Jordan"). In sum, in the agriculture industry, like in other areas, Jordan had to make some difficult concessions, but was also granted significant flexibility in recognition of its status as a developing country. 


\subsection{Saudi Arabia}

Saudi Arabia is among the largest, most populous and wealthiest countries in the Middle East. Saudi Arabia's government is a monarchy. However, since 2005, King Abdallah has implemented modest democratic reforms to promote increased participation in the political system. With a per capita GDP of US $\$ 24,200$, its 26 million inhabitants enjoy a relatively high standard of living. Saudi Arabia's economy is highly dependent on oil, with the petroleum sector accounting for 80 percent of government revenue, 45 percent of GDP and 90 percent of exports. It is the world's largest oil exporter and holds more than 20 percent of the world's proven petroleum reserves. Economic reform and diversification are priorities for the Saudi government. In the last two decades the Saudi government has invested heavily in education and sought to promote the development of various sectors such as power generation, telecommunications, natural gas and petrochemicals. Despite its reform agenda, the government maintains control over most major economic activities in Saudi Arabia (CIA "Saudi Arabia").

Like Jordan, Saudi Arabia embarked on a program of major economic restructuring and market reform in the early 1990s. The central objectives of this program were to promote economic diversification, thereby weaning the economy from its oildependency, and to create employment opportunities for the country's rapidly growing workforce. These outcomes were to be achieved through the creation of a more stable and business-friendly economic environment. WTO accession was seen as a cornerstone of this process (Chemingui and Safadi 1). In addition to being a catalyst for domestic reforms, the Saudi government saw accession as a means to secure improved market access for key export sectors, namely petrochemicals. Finally, as Saudi Arabia was the 
last Gulf Cooperation Council (GCC) member-state and one of the last major economic powers to join the WTO, the government also saw accession as essential to being seen as a serious and credible player in the global economy and a destination for foreign investment (Hertog 5-6).

Saudi Arabia applied to join the GATT in 1993 and became a WTO member 12 years later in December 2005. The challenges faced by the Saudi government over the course of the accession process are remarkably similar to those faced by Jordan. Although the Saudi public service had a large number of Western-educated pro-trade technocrats, particularly among senior management, this group was not sufficiently organized to act cohesively and effectively to advance a reform agenda. Saudi Ministries tend to operate in silos, giving the bureaucratic system a disjointed character and making it very difficult to deal with the cross-cutting issues involved in the accession process. Reform efforts were further impeded by a lack of technical expertise and general sluggishness in the lower levels of the bureaucracy. Rivalries and competition between implicated ministries and agencies were another challenge. The WTO portfolio was formally assigned to the Ministry of Industry and Commerce (MoC), which, until then had not been a very influential player within the Saudi government. Consequently, the MoC often had great difficulty pushing through trade liberalizing reforms that threatened entrenched interests of other more powerful ministries (Hertog 7-10).

Conducting effective stakeholder consultations was another major challenge for the Saudi government. Much like the bureaucracy, the private sector was generally underinformed about WTO issues and not well organized to participate in the accession process. There was widespread apprehension that accession would allow large 
multinational corporations to steamroll local business and that economic globalization presented a danger to the moral traditions of Islam. However, these concerns never congealed into clearly articulated policy options or meaningful policy debate (Hertog 11 14). Government also bears some responsibility for the ineffectiveness of stakeholder consultations. Despite holding many meetings and "producing lots of paper", interactions between the public and private sector were largely ad hoc, limited to small audiences and did not address the substance of the negotiations. The MoC was reportedly very secretive about key negotiating issues for fear of media leaks and backlash from the public and business groups (14-15). In essence, despite some efforts by the MoC, the Saudi government was not able to break from its tradition of state paternalism and consequently the private sector acted largely as a policy-taker in the accession process.

As a result of the aforementioned capacity constraints and the limited influence of the MoC, the early years of the accession process were very difficult for Saudi Arabia. Its initial market access offer was widely criticized for the proposed high tariff bindings and the exclusion of key service sectors (Hertog 16-17). The US and the EU in particular, were pushing for liberalization in a number of key service sectors such as distribution, banking, insurance and telecommunications (17-18 and 20). The widespread regulatory reform needed to align domestic laws with WTO rules in areas such as TRIPS, SPS, TBT and customs valuation was another major bureaucratic struggle (Chemingui and Safadi Annex 1). By 2000, the MoC had exhausted its negotiating ability and made a decision to put the accession process on hold for two years in order to improve institutional capacity (Hertog 16-17). 
Saudi Arabia's accession bid did not regain serious momentum until April 2003, when Mr. Hashim Yamani was appointed as Minister of Commerce. Yamani holds a PhD from Harvard University and is highly regarded as a pragmatic technocrat. He is also said to have a good working relationship with King Abdallah (then Prince), who was eager to advance his agenda of economic reform (Hertog 18-19). Another enabling factor was that by 2003 , Saudi Arabia had also implemented the GCC common external tariff and reduced most import duties to five percent (Oxford Analytica). While Saudi Arabia's average WTO tariff binding of 11.1 is not particularly low, GCC commitments keep its applied rates considerably lower. For example, Saudi Arabia's average applied tariff in 2011 was 4.8 percent (WTO "Trade Profiles - Kingdom of Saudi Arabia").

As the accession process progressed, liberalization of the services industry proved to be by far the most important and contentious aspect of the negotiations. Saudi Arabia's Foreign Direct Investment Law of April 2000 was seen as particularly problematic as it included a lengthy list of service sectors that were closed to foreign investment, including insurance, telecommunications, banking and distribution among others (Chemingui and Safadi Annex 1). With prerequisite backing from the royal family, Saudi negotiators yielded to foreign pressure and eventually agreed to a broad range of commitments on services. In the insurance and banking sectors Saudi Arabia agreed to allow foreign companies to operate as branches or in joint-ventures, in which they are limited to 60 percent ownership. Saudi Arabia opened the telecommunications sector to foreign investment, and agreed to raise the foreign ownership ceiling to 70 percent within three years from the date of accession. The most politically difficult concession came in the distribution sector, which was opened to foreign investment with a 75 percent foreign 
ownership limit (WTO "Schedule CLVIII Saudi Arabia"). Control of so-called 'Trade Agencies', which held exclusive rights to import and distribute products had been a core privilege of the Saudi business community. Many prominent Saudi businessmen had started their careers in this sector and still owned large numbers of very lucrative Trade Agencies. In 2000, a law drafted by the MoC proposing to abolish the monopolistic trade agencies was easily defeated in Majlis Ash-Shura (the closest thing Saudi Arabia has to a legislature) after fervent protests from the head of the Saudi Council of Chambers of Commerce and other powerful business interests (Hertog 17-18). Indeed, the difficulties surrounding this issue were an important contributor to the stagnation of Saudi's accession bid in the early 2000s. Thus, Saudi Arabia's concessions in this area were seen as very symbolically important and illustrative of the government's renewed commitment to economic reform.

The preceding case studies have shown that research findings presented in this paper appear equally applicable to transition and non-transition economies. Jordan and Saudi Arabia faced many of the same challenges in the accession process as the previously examined transition economies. Governments in both countries suffered from shortages of trade policy expertise and struggled to effectively manage stakeholder consultations and integrate feedback from the business community into negotiation strategies. While there is no doubt that Jordan had to undergo some difficult reforms in order to become a WTO member, it was also granted certain flexibilities commensurate with its developing country status. In some respects, this parallels the experiences of Kyrgyzstan and Mongolia. Saudi Arabia on the other handed seems to have been granted less flexibility, particularly in the service industry, where there were very lucrative 
opportunities for foreign investment. WTO members extracted significant and politically difficult market access concessions that pushed the limits of the government's commitment to economic reform and caused the accession process to drag on for many more years than was initially hoped. As in the cases of Vietnam and China, Saudi Arabia did not become a WTO member until its senior political leadership developed a firm commitment to trade liberalization. 


\section{SUMMARY OF FINDINGS AND CONCLUSION}

\subsection{Summary of Findings}

The results of the case studies are generally consistent with the quantitative research findings and support the main hypothesis put forth in this paper. With respect to the first part of this hypothesis, economic factors such as economy size, the value of international trade and trade diversity appear to be important determinants of the degree of negotiating scrutiny to which an acceding country's trade policies and practices are subjected during the accession process. There is no doubt that WTO members have invested far more time, energy and resources into the accession negotiations of countries that play a larger role in the global economy relative to the smaller players. This general trend is reflected in all of the quantitative measures examined in this paper, as well as in official records and other accounts of the negotiations. In this regard, the plethora of available research and analysis on seemingly every imaginable aspect of China's accession negotiations, its outcomes and its implications, is a telling contrast to the scarcity of research and analysis on the WTO accessions of Kyrgyzstan, Mongolia Jordan and even Ukraine and Saudi Arabia.

Concerning the second part of the main hypothesis - that countries with larger economies and more valuable and diversified trade profiles are required to undergo more trade liberalization in the accession process - the evidence is somewhat mixed. Certainly, on balance, countries that play a larger role in the global economy have had to undergo more trade liberalization in order to become WTO members. This is trend is borne out in both the quantitative research findings and the case studies. China is perhaps the best example. Although China was granted generous transition periods to phase in some 
difficult reforms, its final WTO commitments set a new standard for trade liberalization and in effect, raised the bar for subsequent accessions. This can be observed most directly in Vietnam's commitments on TRIMS, trading rights and trade in services, which closely reflect those of China. Furthermore, as we have seen, the prevalence of so-called WTOplus obligations and WTO-minus rights among its commitments is also unique to China's accession.

In contrast, other cases can be interpreted to support the competing hypothesis that larger countries are better equipped for the negotiating process and are able to use their market power to resist pressure from WTO members and pursue strategic negotiating objectives. Russia provides the best example here, as it successfully resisted significant pressure from the US on the issue of branch banking and also secured significant departures from WTO precedents to accommodate its plans to subsidize Russian agricultural production, protect domestic meat producers from import competition and stimulate the automobile manufacturing sector. These findings suggest that the increased negotiating scrutiny associated with being a larger player in the global economy does not always uniformly result in more trade liberalization.

Aside from economic factors, the case studies highlight the influence of international and domestic politics on the accession process and its outcomes. In regard to international politics, Kyrgyzstan's and Mongolia's accession negotiations were motivated and facilitated by each country wanting to signal to the world that it was serious about economic reform and by the West's desire to bring former communist countries into the international, and inherently capitalist, trading system. In other words, overarching political objectives may have made Kyrgyzstan and Mongolia more willing 
to accept difficult economic reforms, while perhaps motivating certain working party members to be less hawkish in their demands for trade liberalization. It could also be argued that Ukraine's political desire to accede to the WTO before Russia and the joint American and European desire for Ukraine to adopt a more western orientation (both politically and economically) had a similar effect on its accession negotiations. Finally, as we have seen, Jordan's accession bid received a considerable boost from its peace treaty with Israel.

With respect to domestic politics, the emergence of a strong political consensus in favour of further integration into the global economy was a critical factor that gave negotiators the policy space to make the concessions required to conclude the accession process in the cases of Ukraine, Vietnam and China. The fact that such a consensus never truly emerged in Russia is a major reason why its accession negotiations suffered long bouts of stagnation and took over 18 years to conclude. Although Russia is widely expected to formally become a WTO member in 2012, some observers are not taking for granted that the Duma will ratify the accession protocol. Similarly, in the case of Saudi Arabia, significant progress toward WTO membership was not achieved until King Abdallah (then prince) lent his leadership and political clout to the economic reform process.

In terms of examining the different influences domestic politics can have on the accession process, the China-Russia comparison is particularly instructive. Their accession negotiations have many similar characteristics in that they are by far the two largest players in the global economy to seek WTO membership and were subjected to considerably more negotiating scrutiny than other acceding country. However, the 
outcomes of their respective negotiations have some important differences. Most notably, Russia secured some significant departures from WTO precedents and, upon accession will not be subject to the various WTO-minus rights that were part of China's commitments. Why were Chinese negotiators so much more flexible than their Russian counterparts? As we have seen, China's political leadership made a determination that continued integration into the global economy was the best strategy to preserve their legitimacy. In Russia's case, the current political leadership seems to vacillate between a preference for protectionist measures that capitalize on nationalistic sentiment, and a more forward looking reform agenda focused on global economic integration and modernization. The somewhat tenuous position of reform-minded actors within Russia's opaque political system seems to have worked to the advantage of Russian WTO negotiators in the sense that it helped them to secure maximum flexibility from WTO members vis-à-vis trade liberalisation and the implementation of difficult reforms. In other words, Russian negotiators were facing a very strong domestic veto and perhaps had significantly less policy space than their Chinese counterparts within which to negotiate WTO commitments.

Notwithstanding these examples, the influence of political factors should not be overstated. In the cases of Kyrgyzstan and Mongolia, political factors appear to have played a larger role in shaping the negotiations only because there was so little at stake for WTO members from an economic perspective. In Russia's case, despite the political pressures to conclude negotiations and the political gains to be derived from Russia's WTO membership (e.g. the conclusion of negotiations was a major boon for the Obama Administration's so called 'reset' in US-Russia relations), the US and other members 
continuously sought to push Russian negotiators to the end of their mandate on various issues and insisted throughout the process that Russia would only be allowed to become a WTO member on 'commercially viable terms'. In addition, a major reason why WTO accession was not as high a priority for Russia's political leadership as it was for China's is that, from an economic perspective, Russia has less to gain. While over the long-term greater exposure to international competition will no doubt help Russia to modernize its economy, in the short-term, Russia has relatively less to gain from WTO membership as its key exports (oil and gas) do not face significant trade barriers. ${ }^{30}$ Thus, while political factors can undoubtedly influence accession negotiations, they often take a back seat to economic factors, particularly when the commercial stakes are high.

\subsection{Conclusion}

This paper set out to explore the effects of the size of an acceding country's economy, the value trade flows and its trade diversity on its accession negotiations and their outcomes. Quantitative and qualitative research findings have shown that acceding countries that play a larger role in the global economy are generally subjected to increased scrutiny from WTO members. This finding reflects the rational decisionmaking of WTO members who chose to invest greater resources in negotiations that are of greater consequence to them from an economic perspective. Research findings have also shown that larger players in the global economy are generally required to undergo more trade liberalization in order to join the WTO. However, this relationship is

\footnotetext{
${ }^{30}$ Perhaps the most notable short-term gain Russia will experience from becoming a WTO member is its removal from coverage of the Jackson-Vanick amendment. This amendment is a vestige of the Cold War that denies MFN treatment to certain non-market economies. Although the amendment contains a waiver provision that has allowed the US to grant Russia MFN status since the end of the Cold War, this waiver must be renewed annually and has at times been subject to congressional opposition. Because of its discriminatory nature, the Jackson-Vanick amendment is inconsistent with WTO rules.
} 
comparatively less strong and is subject to greater influence from non-economic factors, namely politics. Moreover, larger countries appear to be generally better equipped to manage the accession process and, by virtue of their superior negotiating leverage, are sometimes able to more effectively define and defend strategic interests. On the whole, these findings suggest that economic factors are indeed the fundamental determinants of how a prospective WTO member is treated during the accession process. However, in any given case, particularly when there is little at stake from a commercial perspective, political factors can bear a significant influence on negotiations and their outcomes.

What implications do these findings have for current and future WTO accession negotiations and for the accession process itself? With respect to current and future accessions, the research findings suggest that trade policy practitioners in acceding countries should approach the negotiations with a primary focus on economic matters, while being cognizant of both domestic and international political factors that could hinder the accession process or create a political window for its conclusion. For instance, had Russia engaged more seriously in negotiations during the early years of the accession process, it may well have been able to capitalize on lingering fears among western countries that communism would re-emerge and join the WTO in the latter half of the 1990s, under less stringent demands for liberalization than it faced in recent years. Additionally, to the extent possible, acceding countries should make efforts to enhance their understanding of the accession process and WTO rules, prior to, or as early as possible, in the negotiations. In this regard, capacity-building efforts by the WTO Secretariat and WTO members are critical. Improved negotiating capacity on the part of acceding countries can help them to avoid the type of mismanagement and inertia that 
plagued the early years of Ukraine's and Russia's accession negotiations. Moreover, it can help mitigate implementation challenges, such as those experienced by Kyrgyzstan and Mongolia, and avoid the type of criticism they faced about the accession process lacking transparency and not being well understood or positively perceived by the private sector.

The implications of research findings for the accession process itself are best understood against the backdrop of the critiques of the process addressed in chapter three. The central critique is that the price of accession, in terms of trade liberalization, is high and frequently includes commitments that involve so-called 'WTO-plus' obligations and 'WTO-minus' rights. This is said to be particularly challenging for small, developing countries that often face significant capacity constraints in the negotiating process and struggle to deal with the adjustment costs associated with trade liberalization.

These arguments are reminiscent of some of the observers who criticised Kyrgyzstan's and Mongolia's 'unfavourable' terms of accession. However, as we have seen, such criticism had more to do with the mismanagement of the accession process and the implementation of WTO commitments than the actual commitments themselves. In Mongolia's case in particular, the trade liberalization that went hand-in-hand with WTO accession has been critical in attracting foreign capital to the mining sector and turning it into an engine of growth for the economy as a whole. Even one of the more critical observers ultimately concludes that Mongolia's WTO membership "has not been too painful". These observations are supported by quantitative research findings that show that countries with a smaller role in the global economy, which is characteristic of most developing countries that have acceded to the WTO, are generally subjected to less 
negotiating scrutiny and required to undergo less trade liberalization. Thus, while the accession process may still prove challenging for some small, developing countries, in relative terms, the demands placed on them are less exacting than those faced by countries with larger and more globally integrated economies.

More broadly, and putting political considerations aside, there is something inherently illogical about criticising the members of an institution that defines itself as "...the international organization whose primary purpose is to open trade for the benefit of all [emphasis added]"(WTO "Mission Statement"), for asking prospective members to open their economies. Put differently, the institutional foundations of the WTO are based on a belief that trade liberalization is an important driver of economic growth. Since the WTO is truly a membership-driven organization, at least in general terms, most members and prospective members share this belief and espouse the ideal of pursuing a more open international trading system. Based on this shared ideal, it stands to reason that WTO members should exact the maximum possible trade liberalizing concessions from acceding countries, and that acceding countries, in turn, should be willing to liberalize trade to the maximum amount possible within the political constraints they face. In terms of maximizing welfare gains from trade, this would be the optimal strategy for all parties involved. This line of reasoning also applies to the adoption of WTO-plus obligations. As we saw in chapter three, such commitments are typically within the spirit of trade liberalization and seek to strengthen multilateral disciplines. Therefore, they should help governments to adopt more efficient policies and help to boost trade and investment.

In contrast, commitments that involve WTO-minus rights cannot be defended from an economic standpoint. They are patently protectionist and arise from the 
sometimes ugly marriage of political and economic objectives inherent in the mercantilist bargaining that characterizes international trade negotiations. The only redeeming quality of such commitments is that they come with expiration dates. China's textile safeguard and product-specific safeguard are no longer in effect, while the 'non-market economy' designations for China and Vietnam are scheduled to expire in 2016 and 2019 respectively. Also, given that future accessions are unlikely to garner the same attention from WTO members as did China's and Vietnam's, similar commitments are unlikely to be reproduced to any great extent in the future.

This paper began with the observation that the only guidance provided in WTO legal texts about the accession process is that countries may accede to the organization "on terms to be agreed". Despite the evolution of some common principles and procedures the process remains open-ended and inherently flexible. As we have seen throughout this paper, the experiences of different countries have varied widely and, to some extent, WTO members redefine the rules for each individual accession. Is this a good thing? Is this fair? As Russian and Chinese negotiators would certainly point out (and they have repeatedly), it is probably not entirely fair. However, in this author's view, it is nevertheless a good thing. The inherent flexibility in the accession process has allowed WTO members to concentrate finite negotiating resources in areas where they are most economically consequential - the accessions of countries with larger economies and more valuable and diversified trade profiles. Comparatively, some countries with smaller economies and less valuable and diversified trade profiles have, to some extent, been able to 'fly under the radar'. This strategy has allowed WTO members to exact maximum liberalizing concessions from the countries where it matters most, thereby 
strengthening the rules-based international trading system and maximizing welfare gains that can be derived from it. On the other hand, this strategy has also resulted in WTO members being less demanding in their negotiations with countries with smaller economies, thereby facilitating their entry into the WTO and mitigating some of the political and economic difficulties than can be associated with accession. To the extent that this has helped to sustain the continuous expansion of WTO membership and made the organization more globally inclusive, this trend should be seen in a positive light. 


\section{WORKS CITED}

Al Khouri, Riad. "Country Study on Jordan." Ed. Simon J. Evenett. Preparing for WTO Accessions: Insights from Developing Countries. Bern: World Trade Institute (2005): 172-226. Web. 11 Jan. 2012.

Aslund, Anders. "Aftermath of the Orange Revolution, 2005-2008." How Ukraine Became a Market Economy and Democracy. Washington: Peter G. Peterson Institute for International Economics, 2009. 201-236. Print.

---. "Why Doesn't Russian Join the WTO." The Washington Quarterly (2010): 49-63. Web. 30 Mar. 2011.

Axelrod, Robert and Robert O. Keohane. "Achieving Cooperation under Anarchy: Strategies and Institutions." World Politics 38.1 (1985): 226-264. Print

Bachrach, Samuel and Edward Lawler. "Power Dependence and Power Paradoxes in Bargaining." Negotiation Journal 2.2 (1986): 167-174. Print

Bhala, Raj. "Enter the Dragon: An Essay on China's WTO Accession Saga." American University International Law Review 15.6 (2000): 1469-1538. Web. 14 Aug. 2011.

Boumellassa, Houssein and Hugo Valin. "Vietnam's Accession to the WTO: Ex Post Evaluation in a Dynamic Perspective." Économie Internationale 118 (2009): 1342. Web. 12 Feb. 2011.

Braga, Carlos Primo et al. Accession to the WTO: Country Experiences and Technical Assistance. A Joint BMZ BMWA GTZ World Bank Conference 2004. Ed. Silke Trumm. Eschborn: Deutsche Gesselchaft für, 2005. Web. 30 Mar. 2011.

Brandt, Loren and Thomas G. Rawski. "China's Great Economic Transformation." China's Great Economic Transformation. Eds. Loren Brandt and Thomas G. Rawski. New York: Cambridge UP, 2008. 1-26. Print.

---. "China's Great Economic Transformation: Thirty Years of Change Have Modernized China's Economy." China Business Review (2008): 30-33. Web. 30 Mar. 2011.

Brandstetter, Lee and Nicholas Lardy. "China's Embrace of Globalization." NBER Working Paper Series (2006). Web. 30 Mar. 2011.

Brink, Lars. New Members of the WTO: Their Commitments in Agriculture and Provisions Proposed in the Doha Negotiations. International Conference: Agricultural Policy Reform and the WTO: Where are we Heading? Capri Italy, 2003. Web. 12 Feb. 2011. 
Business Week Magazine. "China is a Private Sector Economy." 22 Aug. 2005. Web. 12 Aug. 2011.

Carleton University Centre for Trade Policy and Law. Web. 20 Sep. 2011

Cattaneo, Olivier and Carlos Primo Braga, "Everything You Always Wanted to Know about WTO Accession (But Were Afraid to Ask)." World Bank Policy Research Working Paper 5116. (2009). Web. 12 Sep. 2010.

Chang, Roberto, Linda Kaltani, and Norman Loayza. "Openess can be good for growth: The role of policy complementaries." Journal of Development Economics, 90.1 (2009): 33-49. Print.

Chaponniere, Jean-Raphaël and Jean-Pierre Cling. "Vietnam's Export-Led Growth Model with China." Économie Internationale 118 (2009): 101-130. Web. 12 Feb. 2011.

Chemingui, Mohamad A. and Raed Safadi. Saudi Arabia's Long Road to WTO Membership - The Potential Payoffs. Economic Research Forum Conference Paper \# 122005030, 2005. Wed. 17 Jan. 2012.

Cling, Jean-Pierre et al. "The Distributive Impact of Vietnam's Accession to the WTO." Économie International 118 (2009): 43-71. Web. 12 Feb. 2011.

"Country Reviews: Kyrgyzstan." Globalization, WTO and the NIS: the Dialogue for Sustainable Development. Trade Eco-Accord.org. Web. 12 Feb. 2011.

Dollar, David and Aart Kraay. "Trade, Growth and Poverty." The Economic Journal 114 (2004): 22-49. Web. 13 Dec. 2010.

Dollar, David. "Outward-oriented Developing Economies Really Do Grow More Rapidly: Evidence from 95 LDCs, 1976-1985." Economic Development and Cultural Change (1992): 523-544. Web. 13 Dec. 2010.

Drabek, Zdenek and March Bacchetta. "Tracing the Effects of WTO Accession on Policy-making in Sovereign States: Preliminary Lessons from the Recent Experiences of Transition Countries." The World Economy 27.7 (2004): 10831125. Print.

Drahos, Peter. "When the Weak Bargain with the Strong: Negotiations in the World Trade Organization." International Negotiation 8.1 (2003): 79-109. Print.

Dymond, Bill and Michael Hart. "Navigating New Trade Routes: The Rise of Value Chains, and the Challenges for Canadian Trade Policy." C.D. Howe Institute Commentary 259 (2008). Print. 
Economy Watch Database. Web. 24 Jul. 2011.

Evenett, Simon. A Summary Report of the Discussion on Improving the Accession Process in the $21^{s t}$ Century. Conf., 2006 Session organized by the International Development Research Centre, Canada, at the WTO Public Forum. Web. 15 Nov. 2010

Evenett, Simon and Carlos Primo Braga. "WTO Accession: Moving the Goalposts?" Ed. Richard Newfarmer. Trade Doha and Development: A Window Into the Issues. Washington, D.C.: World Bank, 2006. Web. 18 Nov. 2010.

Frankel, Jeffrey and David Romer. "Does Trade Cause Growth?" The American Economic Review 89.3 (1999): 379-399. Jstor. Web. 13 Dec. 2010.

Gao, Henry. "China's Participation in the WTO: A Lawyer's Perspective." Singapore Year Book of International Law (2007): 1-34. Web. 30 Mar. 2011.

Guohua, Yang and Cheng Jin. "The Process of China's Accession to the WTO." Journal of International Economic Law (2001): 297-328. Web. 12 Feb. 2011.

Granovsky, Vladimir, Igor Burakovsky and Vassyl Yurchyshyn. "The WTO-Ukraine Negotiation Process: Results and Prospects." Ed. Serhiy Khomenko. Strategic Objectives for Ukraine. Ukraine: Agency for Humanitarian Technologies, 2002. Web. 24 Apr. 2011.

Harrison, Ann. "Openness and Growth: A Time-series, Cross-country Analysis for Developing Countries." Journal of Development Economics 48 (1996): 419-447. Web. 13 Dec. 2010.

Hertog, Steffen. "Two-level negotiations in a fragmented system: Saudi Arabia's WTO accession." Review of International Political Economy 15.4 (2008): 1-32. Web. 17 Jan. 2012.

Ianchovichina, Elena and Will Martin. "Trade Liberalization in China's Accession to the World Trade Organization.” World Bank. (2001). Web. 12 Feb. 2011.

Inside Washington. "Inside U. S. Trade". An Inside Washington Publication 29.6 (2011): 2-20. Web. 30 Mar. 2011.

Kong, Qingjiang. "China's WTO Accession: Commitments and Implications." Journal of International Economic Law (2000): 655-690. Web. 30 Mar. 2011.

Krugman, Paul R. "Increasing Returns, Monopolistic Competition, And International Trade." Journal of International Economics 9 (1979): 469-479. Web. 7 Jan. 2011. 
Langhammer, Rolf and Matthias Lucke. "WTO Negotiations and Accession Issues For Vulnerable Economies." Kiel Working Paper 990 (2000). Web. 10 Sep. 2010.

Lardy, Nicholas R. Integrating China into the Global Economy. Washington D.C.: The Brookings Institution Press, 2002. Print.

Lawrence, Roger. "The Benefit of Joining WTO.” Eds. Ihor Burakovsky, Lars Handrick and Lutz Hoffman. Ukraine's WTO Accession: The Challenge for Domestic Economic Reforms. New York: Physica-Verlag Heidelberg, 2004. Web. 9 Aug. 2011

Mai, Chang and Liam Lacey. "Effects for the Kyrgyz Republic After Joining the WTO" Conf., World Trade Insitute EU-LDC Network Conference, 8-10 Oct. 2002. Web. 15 November 2010.

Malkawi, Bashar H. "Jordan's Accession to the WTO: Retrospective and Prospective." The Estey Centre Journal of International Law and Trade Policy 11.1 (2010): 1245. Web. 4 Jan. 2012.

Mankin, Mark E., William H. Cooper and Bernard A. Gelb. "Vietnam PNTR Status and WTO Accession: Issues and Implications for the United States." CRS Report for Congress (2006): 2-27. Web. 30 Mar. 2011.

Melitz, Marc J. "The Impact of Trade on Intra-Industry Reallocation and Aggregate Industry Productivity." Econometrica 71.6 (2003): 1695-1725. Web. 7 Jan. 2011.

Metcalfe, Brian. Foreign Banks in China. Pricewaterhouse Coopers Limited, 2011. Web. 4 July 2011.

Michalopoulos, Constantine. "Developing Countries' Participation in the World Trade Organization." World Bank Policy Research Working Paper 1906 (1998). Web. 14 Oct. 2010.

Mongolia. Ministry of Foreign Affairs and Trade. WTO Accession Experience of Mongolia. Ulaanbaatar: Department of Foreign Trade and Economic Cooperation, 2010. Web. 11 Jul. 2011.

Naray, Peter. Russia and the World Trade Organization. New York: Palgrave, 2001. Print.

Ohlin, Bertil. Interregional and International Trade. Cambridge, MA: Harvard University Press, 1967. Print

Oxford Analytica. "Saudi Arabia: WTO accession to yield gradual change." Oxford Analytica Daily Brief Service, 2005. Web. 15 Jan. 2012. 
Oyuntsetseg, H. "Experiences from Monglia." Silke Trumm. Ed. Accession to the WTO: Country Experiences and Technical Assistance. Bonn: German Technical Cooperation Agency, 2005. Web. 14 Jun. 2011.

Pomfret, Richard. "Lessons from Kyrgyzstan's WTO Experience for Kazakhstan, Tajikistan and Uzbekistan." Asia-Pacific Trade and Investment Review 3.2 (2007): 27-46. Web. 30 Mar. 2011.

Qin, Julia Ya. "WTO-Plus" Obligations and Their Implications for the World Trade Organization Legal System." Journal of World Trade 37.3 (2003): 483-522. Web. 30 Mar. 2011.

Ricardo, David. On the Principles of Political Economy and Taxation. $3^{\text {rd }}$ ed. London: John Murray, 1821. Print

Rodriguez, Francisco and Dani Rodrik. "Trade Policy and Economic Growth: A Skeptic's Guide to the Cross-National Evidence." Trade Policy and Economic Growth (1999): 261-325. Web. 7 Jan. 2011.

Rose, Andrew K. "Do We Really Know That the WTO Increases Trade?" American Economic Review 94.1 (2004): 98-114. Web. 7 Jan. 2011.

Rumbaugh, Thomas and Nicolas Blancher. "China: International Trade and WTO Accession." International Monetary Fund Working Paper 36.4 (2004): 1-25. Web. 12 Feb. 2011.

Sachs, Jeffery D., Anders Aslung, Andrew Warner and Stanley Fisher. "Economic Reform and the Process of Global Integration." Brooking Papers and Economic Activity 1995.1 (1995): 1-118. Jstor. Web. 13 Dec. 2010.

Sam, Phan Van and Vo Thanh Thu. "Preparation by Viet Nam's Banking Sector for WTO Accession." Managing the Challenges of WTO Participation - 45 Case Studies." Eds. Peter Gallagher, Patrick Low and Andrew Stoler. UK: Cambridge UP, 2005. 621-633. Print.

Smith, Adam. An inquiry into the nature and causes of the wealth of nations. $5^{\text {th }} \mathrm{ed}$. Ed. Edwin Cannan London: Methuen and Co. Ltd, 1904. Print.

Steinberg, Richard H. "In the Shadow of Law or Power?: Consensus-Based Bargaining and Outcomes in the GATT/WTO," International Organization 56.2 (2002): 339374. Print.

Subramanian, Arvind and Shang-Jin Wei. "The WTO promotes trade, strongly but unevenly." American Economic Review, 72.1 (2007): 151-175. Print. 
Tang, Man-Keung and Shang-Jin Wei. "The value of making commitments externally: Evidence from WTO accessions." Journal of International Economic, 78 (2009): 216-229. Print.

Tarr, David. "Russian WTO Accession: What has been Accomplished, What can be Expected." Policy Research Working Paper 4428 (2007): 2-18. Web. 30 Mar. 2011.

The Economist. "China Opens Up." The Economist, 20 Nov. 1999. Web. 05 Aug. 2011.

--.. "Entry Secured - Ukraine is set to join the WTO in May." The Economist, 14 Apr. 2008. Web. 22 Apr. 2011.

---. "The other Asian Miracle - Special Issue on Vietnam." The Economist, 24 Apr. 2008. Web. 25. Jul. 2011.

Tran, Boa Toan. "Analysis of the Vietnamese Banking Sector with special reference to Corporate Governance." Diss. U of St. Gallen, 2008. Web. 30 Mar. 2011.

Tsogtbaatar, Damdin. "Mongolia." Eds. Patrick Macrory, Arthur Appleton and Michael Plummer. The World Trade Organization: Legal, Economic and Political Analysis, Volume 3. New York: Springer Science+Business Media Inc., 2005. 249-267. Web. 27 Jul. 2011.

---. "Mongolia's WTO Accession: Expectations and Realities of WTO Membership" World Trade Organization. Peter Gallagher, Patrick Low, Andrew L. Stoler. Eds. Managing the Challenges of WTO Participation - 45 Case Studies. Cambridge: Cambridge University Press, 2005. Web. 27 May 2011.

United Nations Global Indicators Database. Web. 14 Jan. 2011.

United States. Central Intelligence Agency. "World Fact Book - China." Web. 14 Jan. 2011.

--. "World Fact Book - Jordan." Web. 6 Jan. 2012.

---. "World Fact Book - Kyrgyzstan." Web. 13 Aug. 2011.

-.-. "World Fact Book - Mongolia." Web. 12 Jul. 2011.

---. "World Fact Book - Russia." Web. 20 Feb. 2011.

.... "World Fact Book - Saudi Arabia." Web. 9 Jan. 2012.

---. "World Fact Book - Ukraine." Web. 10 Feb. 2011. 
---. "World Fact Book - Vietnam." Web. 20 Jul. 2011.

United States. Department of Agriculture Foreign Agricultural Service. "Russian Federation, Government Program for Agriculture and Market Regulation 20082012" Global Agriculture Information Network Report No RS7051. 2007. Web. 03 Feb. 2011.

United States. Office of the United States Trade Representative. "Special 301 Report." USTR.Gov.2011. Web. 12 Feb. 2011

---. "2008 Report to Congress on China's WTO Compliance." USTR.Gov. 2008. Web. 12 Feb. 2011.

---. "China." 2011 National Trade Estimate Report on Foreign Trade Barriers. USTR.Gov. 2011. Web. 12 Feb. 2011.

---. "Result of Bilateral Negotiations on Russia's Accession to the World Trade Organization: Action on Critical IPR Issues." USTR.Gov. 2006. Web. 12 Feb. 2011.

---. "Result of Bilateral Negotiations on Russia's Accession to the World Trade Organization: Bilateral Market-access Agreement on Services." USTR.Gov. 2006. Web. 12 Feb. 2011

World Bank. "Taking Stock - An Update on Vietnam's Economic Development." Hanoi: World Bank Vietnam Office, 2006. Web. 23 Jul. 2011.

---. "Ukraine's Accession to the WTO: Completing the Negotiations and Maximizing the Benefits of Membership." Ukraine Trade Policy Study (2004): 117-149. Web. 30 Mar. 2011.

--.. "Vietnam Development Report 2009 - Capital Matters." Hanoi: World Bank Vietnam Office, 2009. Web. 23 Jul. 2011.

World Trade Organization. Accession Gateway. Web. 12 Oct. 2010

---. Anti-Dumping Gateway. Web. 28 Aug. 2011.

--.. "Handbook on Accession to the WTO" 2.4 Guidelines on the Accession of Least Developed Countries. Web. 25 July. 2011.

--.. "Protocol on the Accession of the People's Republic of China." (2011). Web. 27 Aug. 2011.

---. "Report of the Working Party on the Accession of the People's Republic of China to the World Trade Organization" (2011): 1-174. Web. 25 Aug. 2011. 
---. "Report of the Working Party on the Accession of the Russian Federation to the World Trade Organization." (2011): 1-604. Web. 18 Dec. 2011.

--.. "Report of the Working Party on the Accession of Ukraine to the World Trade Organization." (2008): 1-237. Web. 30 Mar. 2011.

-.-."Report of the Working Party on the Accession of Viet Nam." (2006): 1-204. Web. 30 Mar. 2011.

-... "Schedule CLXVIII -Jordan." Web. 12 Jan. 2012.

---. "Schedule CXLII - Kyrgyz Republic." Web. 12 Jan. 2011.

---. "Schedule CXXXIV - Mongolia." Web 12 Jul. 2011.

-... "Schedule CLII - People's Republic of China."Web. 5 Aug. 2011.

--.. "Schedule CLXV - Russian Federation." Web. 17 Apr. 2011.

-... "Schedule - CLVIII - Kingdom of Saudi Arabia." Web. 4 Jan. 2012.

---. "Schedule CLXII - Ukraine." Web. 14 Mar. 2011.

--.. "Technical Note on the Accession Process." WT/ACC/7. Web. 13 Sep. 2010.

---. "Technical Note on the Accession Process." WT/ACC/7.Rev.2 Web. 13 Sep. 2010.

---. "Trade Profiles - Ukraine 2010." Geneva: WTO Publications, 2011. Web. 30 Mar. 2011.

--.. "Trade Profiles - Saudi Arabia 2010." Geneva: WTO Publications, 2011. Web. 30 Mar. 2011.

---. "Trade Policy Review - Report by Mongolia." Trade Policy Review Body (2005): 322. Web. 30 Mar. 2011.

--.. "Working Party seals the deal on Russia's membership negotiations". WTO Press Release. 10 Nov. 2011. Web 16 Nov. 2011. 